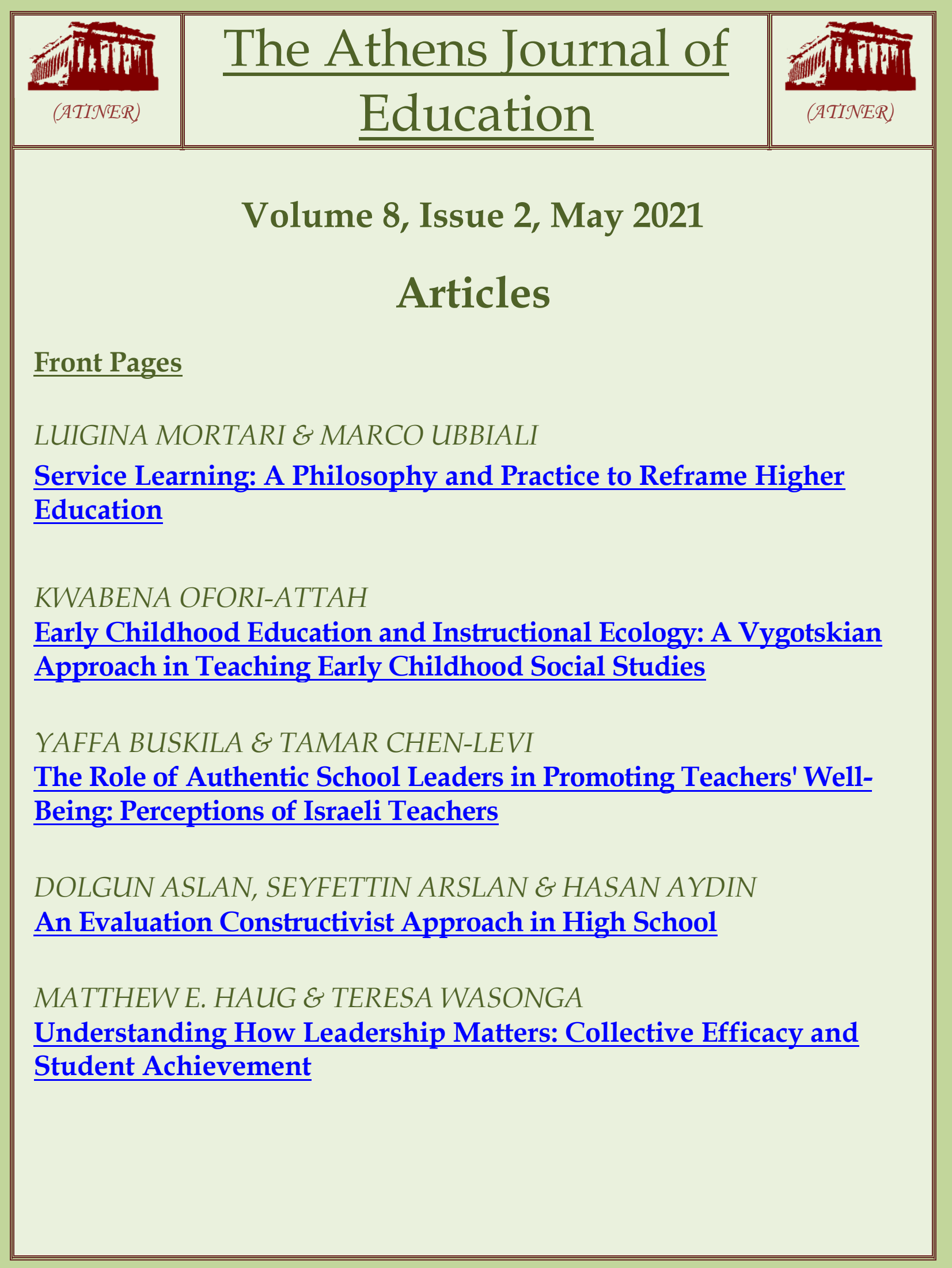




\section{Mission}

ATINER is an Athens-based World Association of Academics and Researchers based in Athens. ATINER is an independent and non-profit Association with a Mission to become a forum where Academics and Researchers from all over the world can meet in Athens, exchange ideas on their research and discuss future developments in their disciplines, as well as engage with professionals from other fields. Athens was chosen because of its long history of academic gatherings, which go back thousands of years to Plato's Academy and Aristotle's Lyceum. Both these historic places are within walking distance from ATINER's downtown offices. Since antiquity, Athens was an open city. In the words of Pericles, Athens"... is open to the world, we never expel a foreigner from learning or seeing". ("Pericles' Funeral Oration", in Thucydides, The History of the Peloponnesian War). It is ATINER's mission to revive the glory of Ancient Athens by inviting the World Academic Community to the city, to learn from each other in an environment of freedom and respect for other people's opinions and beliefs. After all, the free expression of one's opinion formed the basis for the development of democracy, and Athens was its cradle. As it turned out, the Golden Age of Athens was in fact, the Golden Age of the Western Civilization. Education and (Re)searching for the 'truth' are the pillars of any free (democratic) society. This is the reason why Education and Research are the two core words in ATINER's name. 
The Athens Journal of Education

ISSN NUMBER: 2241-7958 - DOI: 10.30958/aje

ISSN (print): 2407-9898

Volume 8, Issue 2, May 2021

Download the entire issue $(\underline{\mathrm{PDF}})$

Front Pages

i-viii

Service Learning: A Philosophy and Practice to

Reframe Higher Education

Luigina Mortari \& Marco Ubbiali

Early Childhood Education and Instructional Ecology: A 139

Vygotskian Approach in Teaching Early Childhood

Social Studies

Kwabena Ofori-Attah

The Role of Authentic School Leaders in Promoting

161

Teachers' Well-Being: Perceptions of Israeli Teachers

Yaffa Buskila \& Tamar Chen-Levi

An Evaluation Constructivist Approach in High School

Dolgun Aslan, Seyfettin Arslan E Hasan Aydin

Understanding How Leadership Matters: Collective

Efficacy and Student Achievement

Matthew E. Haug \& Teresa Wasonga 


\section{Athens Journal of Education Editorial and Reviewers' Board}

Editors

- Dr. John Spiridakis, Academic Member, ATINER \& Professor, St. John University, USA.

- Dr. Alexander Makedon, Head, Education Unit, ATINER.

- Dr. Julia Underwood, Academic Member, ATINER \& Professor, Azusa Pacific University, USA.

- Dr. Zoi Philippakos, Academic Member, ATINER \& Assistant Professor, University of Tennessee, Knoxville, USA.

\section{Editorial Board}

- Dr. Sharon Vaughn, Academic Member, ATINER \& Professor and Executive Director, The University of Texas at Austin and The Meadows Center for Preventing Educational Risk, USA.

- Dr. Effie Kritikos, Academic Member, ATINER \& Professor and Division Chair of Education, Governors State University, USA.

- Dr. Elsa Fourie, Academic Member, ATINER \& Professor \& Director, North-West University, South Africa.

- Dr. Effie Efthymiou, Academic Member, ATINER \& Assistant Professor, United Arab Emirates University (UAEU), UAE.

- Dr. Ashlea Rineer-Hershey, Assistant Professor and Education Transition Programming Coordinator, Slippery Rock University, USA.

- Dr. Lorna Hamilton, Academic Member, ATINER \& Senior Lecturer, School of Education University of Edinburgh, UK.

- Dr. Yaacov Julian Katz, Academic Member, ATINER \& Lecturer and Researcher in Social Psychology of Education, Bar-Ilan University, Israel.

- Dr. Mary Ellis, Academic Member, ATINER \& Senior Lecturer, National Institute of Education (Nanyang Technological University), Singapore.

- Dr. Sandra M. Harris, Academic Member, ATINER \& Assessment Director, Walden University, USA.

- Dr. Jose Francisco Duran Medina, Professor, Department of Pedagogy, University of CastillaLa Mancha, Spain.

- Dr. Roger B. Hill, Professor, University of Georgia, USA.

- Dr. Azita Manouchehri, Professor, Ohio State University, USA.

- Dr. Macleans A. Geo-JaJa, Professor of Economics and Education, David O. McKay School of Education, Brigham Young University, USA.

- Dr. Dijana Karuovic, Professor, Technical Faculty “Mihajlo Pupin” Zrenjanin, Serbia.

- Dr. Mohinder Partap Satija, Professor, Guru Nanak Dev University, India.

- Dr. Aieman Ahmad Al-Omari, Professor, The Hashemite University, Jordan.

- Dr. Michael F. Shaughnessy, Professor, School of Education, Eastern New Mexico University, USA.

- Dr. Trish Stoddart, Professor, Education Department, University of California, USA.

- Dr. Kamini Jaipal Jamani, Associate Professor, Brock University, Canada.

- Dr. Francisco Javier Fernandez Rio, Associate Professor, Educational Sciences Department, University of Oviedo, Spain.

- General Managing Editor of all ATINER's Publications: Ms. Afrodete Papanikou

- ICT Managing Editor of all ATINER's Publications: Mr. Kostas Spyropoulos

- Managing Editor of this Journal: Ms. Despina Katzoli ( $\underline{\text { bio }})$

\section{Reviewers' Board}

Click Here 


\section{President's Message}

All ATINER's publications including its e-journals are open access without any costs (submission, processing, publishing, open access paid by authors, open access paid by readers etc.) and is independent of presentations at any of the many small events (conferences, symposiums, forums, colloquiums, courses, roundtable discussions) organized by ATINER throughout the year and entail significant costs of participating. The intellectual property rights of the submitting papers remain with the author. Before you submit, please make sure your paper meets the basic academic standards, which includes proper English. Some articles will be selected from the numerous papers that have been presented at the various annual international academic conferences organized by the different divisions and units of the Athens Institute for Education and Research. The plethora of papers presented every year will enable the editorial board of each journal to select the best, and in so doing produce a top-quality academic journal. In addition to papers presented, ATINER will encourage the independent submission of papers to be evaluated for publication.

The current issue is the second of the eighth volume of the Athens Journal of Education (AJE), published by the Education Unit of ATINER.

Gregory T. Papanikos

President

ATINER 


\section{Athens Institute for Education and Research}

\section{A World Association of Academics and Researchers}

\section{3rd Annual International Conference on Education 17-20 May 2021, Athens, Greece}

The Education Unit of ATINER organizes its 23rd Annual International Conference on Education, 17-20 May 2021, Athens, Greece sponsored by the Athens Journal of Education. The aim of the conference is to bring together scholars and students of education and other related disciplines. You may participate as stream leader, presenter of one paper, chair a session or observer. Papers (in English) from all areas of education are welcome. Please submit a proposal using the form available (https://www.atiner.gr/2021/FORM-EDU.doc).

\section{Academic Members Responsible for the Conference}

- Dr. Gregory T. Papanikos, President, ATINER.

- Dr. David Philip Wick, Director, Arts, Humanities and Education Division, ATINER \& Professor of History, Gordon College, USA.

- Dr. John Spiridakis, Co-Editor, Athens Journal of Education \& Professor, St. John University, USA.

- Dr. Alexander Makedon, Head, Education Unit, ATINER \& Independent Scholar (Retired Full Professor, Chicago State University, USA).

- Abstract Submission: 5 April 2021

\section{Important Dates}

- Acceptance of Abstract: 4 Weeks after Submission

- Submission of Paper: 19 April 2021

\section{Social and Educational Program}

The Social Program Emphasizes the Educational Aspect of the Academic Meetings of Atiner.

- Greek Night Entertainment (This is the official dinner of the conference)

- Athens Sightseeing: Old and New-An Educational Urban Walk

- Social Dinner

- Mycenae Visit

- Exploration of the Aegean Islands

- Delphi Visit

- Ancient Corinth and Cape Sounion

More information can be found here: $\underline{w w w . a t i n e r . g r / s o c i a l-p r o g r a m ~}$

\section{Conference Fees}

Conference fees vary from $400 €$ to $2000 €$

Details can be found at: https://www.atiner.gr/2021fees 


\section{Athens Institute for Education and Research}

A World Association of Academics and Researchers

\section{$5^{\text {th }}$ Annual International Symposium on "Higher Education in a Global World", 5-8 July 2021, Athens, Greece}

The Education Unit of ATINER is organizing the $5^{\text {th }}$ Annual International Symposium on "Higher Education in a Global World", 5-8 July 2021, Athens, Greece sponsored by the Athens Journal of Education. The aim of the symposium is to examine educational developments throughout the world in universities, polytechnics, colleges, and vocational and education institutions. Academics and researchers from all areas of education are welcomed. You may participate as stream organizer, presenter of one paper, chair a session or observer. Please submit a proposal using the form available (https://www.atiner.gr/ 2021/FORM-COLEDU.doc).

\section{Important Dates}

- Abstract Submission: 8 March 2021

- Acceptance of Abstract: 4 Weeks after Submission

- Submission of Paper: 7 Iune 2021

\section{Academic Member Responsible for the Conference}

- Dr. Gregory T. Papanikos, President, ATINER.

- Dr. Sharon Claire Bolton, Vice President of Research, ATINER \& Professor, The Management School, University of Stirling, Scotland.

- Dr. David Philip Wick, Director, Arts, Humanities and Education Division, ATINER \& Professor of History, Gordon College, USA.

- Dr. John Spiridakis, Co-Editor, Athens Journal of Education \& Professor, St. John University, USA.

- Dr. George Priovolos, Director, Center for Small and Medium-Sized Enterprises (CSME) \& Professor, Iona College, USA.

\section{Social and Educational Program}

The Social Program Emphasizes the Educational Aspect of the Academic Meetings of Atiner.

- Greek Night Entertainment (This is the official dinner of the conference)

- Athens Sightseeing: Old and New-An Educational Urban Walk

- Social Dinner

- Mycenae Visit

- Exploration of the Aegean Islands

- Delphi Visit

- Ancient Corinth and Cape Sounion

More information can be found here: https://www.atiner.gr/social-program

\section{Conference Fees}

Conference fees vary from $400 €$ to $2000 €$

Details can be found at: https://www.atiner.gr/2021fees 


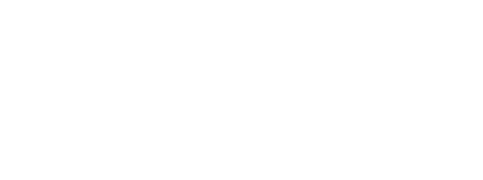




\title{
Service Learning: A Philosophy and Practice to Reframe Higher Education
}

\author{
By Luigina Mortari* \& Marco Ubbiali ${ }^{\dagger}$
}

\begin{abstract}
In order to answer the call of Agenda 2030 (UN, 2015), higher education must assist in giving form to a new society in which democracy is cultivated in both the minds and practices of our society. A democratic education is the answer to the challenges of contemporary society, which is characterized by indifference and an unwillingness to engage for the common good. Educational practices are often aligned to this trend so that they are planned with the aim of developing competences useful for individual success and the economic improvement of society. It is necessary to envision a new design for higher education that promotes in people the disposition to engage in the construction of a society where everyone has an equal opportunity to live a good and fulfilling life. Useful for this purpose can be a rediscovery of the classical position of Plato, Socrates, and Aristotle that present virtue and ethics as a theoretical framework for education. This framework can be used as a foundation upon which to renew academic practices by planning and designing experiences able to translate theory into actions. Service learning is an interesting model that would allow for this and would guide practices that support a democratic education informed by virtue and ethics. If useful for redirecting higher education, service learning is particularly suitable for educating teachers, the practitioners who have a great responsibility for transforming society through education. In this paper, after developing the appropriate theoretical framework, we present, as an example of service learning, the Community Research Service Learning experience carried out at the University of Verona in the Primary Teacher Education master's degree program.
\end{abstract}

Keywords: higher education; service learning; civic engagement; ethics; preservice teacher training.

\section{Introduction}

In order to answer the call of Agenda 2030 (UN, 2015), higher education must assist in giving form to a new society in which democracy is cultivated in both the minds and practices of our society. This democratic education is needed to reverse the drift in our contemporary society that philosophers and sociologists describe as characterized by indifference (Baumann, 2004; Morin, 2007) and a lack of awareness of others, where few feel a sense of responsibility for their neighbors (Boella, 2006, 2018; Lévinas, 1961). As public debates and speeches become increasingly more violent, action for the common good becomes more

${ }^{*}$ Full Professor, University of Verona, Italy.

"Temporary Assistant Professor, University of Verona, Italy. 
dormant; indeed, observing the democratic rules of coexistence is no longer viewed as necessary and honorable (Pulcini, 2009).

This way of thinking is rooted in an individualistic ethic, in which the idea of a "good life" resides in self-affirmation (Baumann, 1999). This self-serving way of interpreting life's purpose is one of the worst risks to democracy (Beck, 1998), and it is further exacerbated by our educational system. Aligned with current trends, educational programs are designed to develop competences useful for individual success and the economic improvement of society (Mortari, 2017, p. 15), resulting in an educational system that takes the form of a "banking model" (Marullo \& Edwards, 2000, p. 746).

In order to give meaning to the globalized world we now live in and compensate for the loss of significance of the common life in the global village, it is necessary to envision a new education that offers a rich, meaningful experience, able to give form to a "good person" and a "good society." The classical ethics teachings of Plato, Socrates, and Aristotle constitute a valid theoretical framework for this purpose. Since, as Aristotle stated, the human being is a political animal, a good and complete form of education should mainly cultivate the dispositions and the competences that are necessary to give our own contribution to the construction of a society where all people can live a life worth living (Plato, Apology of Socrates). However, education is a practice: that is why we need to plan and design educative experiences able to translate theory into actions. According to Dewey (1938), education arises from experience, that is, through contact with the real world (and its challenges and opportunities) and reflection (that gives sense to action). In particular, this experiential education should be aimed at teaching not only technical or cognitive skills, but also the competences that prepare people to become engaged citizens (Dewey, 1916).

Service learning is a very interesting model that provides these theoretical premises with a practical and educational implementation. Many studies, in fact, show how service learning can be considered both a philosophy of education and a didactic method that can be adopted in a wide range of academic courses (see the literature review by Ubbiali, 2017).

\section{Policy, Ethics, and Education}

\section{Ethics and Education}

As Aristotle stated, every being tends to the good (Nichomachean Ethics, Book I, 1, 1094a 2-3). In particular, for the human being the good assumes the form of eudaimonia (Nichomachean Ethics, Book I, 4, 1095a 18-19), which does not simply mean "happiness," as it is very often translated, but suggests a "good quality of the life of the soul": the word, in fact, is composed of the Greek terms $e u$, which means "good," and daimon, which means "spirit" or "soul."

The good is the object of the research of ethics. Ethics cannot be a science because human reason cannot define with evident certainty what good is. A definitive and complete answer to the question "what is the good?" is not possible 
for human beings (Murdoch, 1970, p. 93); at the same time, it is a question that cannot be circumvented, because it deals with human beings' flourishing.

Educating people, and the young in particular, to research for the good (i.e., ethics) is necessary: in fact, if education means to help people to give form to their own existence, and the good form of existence is eudaimonia, research for the good cannot be avoided in scholarly pathways. In this vision, education assumes the form of the Socratic epimeleia, in other words, the care that makes human beings flourish in all their aspects and potentialities (Plato, Alcibiades $1^{s t}$, 130e; Plato, Apology of Socrates, 30b; Noddings, 1984, 1992; Mortari, 2015; Mortari \& Saiani, 2014).

\section{Policy and Education}

Starting from Aristotle's famous expression that defines every human being, in his or her ontological essence, as a "political animal" (zoonpolitikon), Hannah Arendt affirmed that "to live an entirely private life means above all to be deprived of things essential to a truly human life" $(1958$, p. 58). In fact, it is only in the public realm that we can flourish as human beings because we can be enriched by the look of others and nurtured by an "objective" relationship with them "that comes from being related to and separated from them through the intermediary of a common world of things," and therefore, we can reach the "possibility of achieving something more permanent than life itself" (Arendt, 1958, p. 58).

According to Jean Luc Nancy (1996, p. 1), the human condition is a coexistence: that means that every human being is, in his or her ontological singularity, plural: the dynamics of a person's existence can occur only within a net of relationships that gives form to his or her Lebenswelt, i.e., his or her living environment. Every human being, in order to exist according to a human form, has to live together with others, giving form to a world that allows everybody to live a good life. At the basis of co-existence, there is the deep consciousness of a strong connection with others, which is a real dependence: the common life, or better the "res publica," comes from reciprocal dependency. The political dimension of existence not only deals with the personal realization of the single human being, but also takes the form of responsibility: if human beings become entirely private, "they are all imprisoned in the subjectivity of their own singular experience, which does not cease to be singular if the same experience is multiplied innumerable times," which also means the end of the common world because the world itself is "seen only under one aspect," representing a loss for all humankind (Arendt, 1958, p. 57).

It has been noted that human nature has an aptitude for the establishment of socio-semantic systems (see Niklas Luhmann, 1984), especially those called closed and autopoietic social subsystems, in light of the principles of Humberto Maturana and Francisco Varela (Maturana \& Varela, 1980) and which are appropriated by Luhmann himself. The individual is understood as a psychic environment for the socio-semantic system that tends to be a constituent of the individuation process of the subjects.

To live is to coexist, but it is not only a status quo or an ontological condition. It is a fact that human beings are linked together in the world, but coexisting is an 
action that requires an intention, therefore becoming an ethical action. In order to orient coexistence ethically, a sort of director is necessary: this is the aim of policy. To give form to (singular or collective) life means to implement the action of care, the "factory of being," an action that can be devoted to oneself, or to others and the world. When care is devoted to oneself, the human being gives form to his or her own uniqueness; when care is devoted to relationships, many people (in Greek, polloi) give form to the world, and it becomes policy.

The term policy simultaneously designates a practice and the wisdom that informs that practice. The principal actions that define the essence of policy are the ones Plato attributed to Zeus: the great commander in heaven, in fact, is the one who puts in order all things and cares for everything (Plato, Phaedrus, 246e: personal translation from the original Greek version). The order is granted by justice, by the references that guarantee everyone the recognition of the measure of something; care, instead, is the condition that allows every citizen to flourish in his or her personal potentialities.

Following this vision, policy is necessary for humankind: in fact, it is a form of acting guided by the intention to create conditions for a good life, a life that allows everybody to inhabit the earth with others and live a good quality of life experienced within the soul (eudaimonia).

A good policy must be cultivated: it needs education, because without educated minds, there is no possibility to give form to a real human civilization. In the meantime, a good educational policy is necessary, which is a vision of education that serves as a reminder that the political aspect of every life (bios politikos) is essential in order to reach the good, both for every singular being and the whole of humankind. A good policy asks to cultivate minds that look for the good; it asks for an ethics and an education inspired to it.

\section{A Community Vision, to Face the Crisis of Educational Polices}

Therefore, contemporary educational policy needs to be reconsidered and redesigned: in fact, educational institutions are crossing into a deep crisis. Institutional agencies have a complex status, because they should be designed following both u-topic and a-topic lines, tending to a vision of life and of the world that does not stay flattened on the present, but aims towards an ideal that can guide educators.

Instead, we are experiencing a real crisis in educational policies and politics, because they often reflect and reinforce the (non) ethical feeling of our times. Philosophers and sociologists define our society as liberal, based on competition, where the concept of "good life" is intended as self-affirmation (Bauman, 1999); we often feel a sense of indifference towards the other's condition (Bauman, 2001; Morin, 1994). Following this social tendency, even educative pathways tend to present an individualistic approach to learning and, in general, to life. These pathways are very often competitive, thereby nurturing that individualistic view of

\footnotetext{
${ }^{1}$ We use the term policy as the vision adopted and the plan prospected in order to govern a community or an organization; we use the term politics to refer to the activities performed in order to give form to the policy-vision.
} 
life that affirms that a good existence is one that does not care for others or for a common destiny. Therefore, education encourages and cultivates those skills that are useful and functional for a society that adopts an economic evaluation of the meaning of things and the search for self-affirmation.

We cannot forget that our ontological substance is relational, and every singular affirmation is related to the flourish of the others to whom we are related. This is the real wisdom of life, a wisdom that should be put at the center of political attention and, consequently, of educational policies as well. How is it possible to translate these philosophical assumptions into educational practice? This is the task of pedagogy.

In fact, pedagogy is a practical wisdom, because its epistemological foundation is rooted in looking for strategies that facilitate educational processes (Mortari, 2007): a learning through experience that starts from the daily challenges that occur in educational or cultural or community contexts and looks for answers able to orient educative actions. Following the philosophical premises just presented, we can affirm that the teleological aim of education is to cultivate the good for learners (the flourishing of everybody's potentialities) but also for the community they live in (the common good).

If curricular projects are designed following this inspiration, they become real "laboratories of the things in life": places and times where it is possible to imagine new practices for a better life and a better common world; places and times where it is possible to analyze common practices, identify and support good ones, deconstruct ineffective practices, and propose new ways to improve them, while also struggling for the good.

Projects designed according to this vision cannot be confined to school classrooms and textbooks or disciplines, but must be "community engaged," proposing learning that is more complex than simply knowledge or skillslearning that also facilitates care about both the individual's and the community's needs.

Moreover, as explained by Keith (2016), this vision also has important consequences for academic research that can "go further than descriptions, although this is an essential starting point" (p. 23) towards an "approach that supports critical policy analysis and the ability to induce significant change" ( $p$. 24). An important task for pedagogy is to design, plan and evaluate practices able to give form to this philosophical vision of education and answer the challenges of our times. The practice of service learning represents a significant proposal for achieving this, as supported by the literature and by practices taking place throughout the world. 


\section{The Proposal of Service Learning}

\section{A Call for Educational Institutions}

At all levels of education, we assist in the hyper-specialization of technology and hard sciences that develop knowledge in an exponential way but, at the same time, cultivate an analphabetism of civic competences. This is not what the educational system was designed to achieve.

The aim of educational institutions, instead, is to plan and offer quality learning experiences that enable students to develop all aspects of their personalities and to enhance their capacity to think, to feel, and to act with others in the world.

Even J. Dewey underlined that schools and universities are often artificial, where learning objectives are not in sync with real life. Therefore, in order to give form to personal life, it is necessary to design and realize learning contexts that are guided by the "learning by doing" principle (Dewey, 1938) which we can think of as "laboratories of things in life."

Experiential learning methodologies (Kolb, 1984) define an approach that responds to this educational necessity. In his theory, Kolb affirmed that knowledge is generated through the transformation of experience: according to this vision, ideas are not merely fixed objects to be learned; they are concepts that can be formulated and reformulated through contact and engagement with real life.

There is, however, a risk involved in such activities: schools and universities could adopt such practices as an instrument to approach reality (with its challenges and problems) as a "test bench," in other words, in an utilitarian way, aimed only at improving competences and disciplinary abilities, carrying with it the risk of nurturing the competitive and individualistic sensibility they hope to subside. As a solution, there is an approach that links schools and universities to the real world, that goes beyond this instrumental style: it is the service learning (SL) or community service learning (CSL) approach.

Service experiences, that in literature are documented at all educational levels, from kindergarten to higher education (Furco \& Root, 2010; Kielsmeier, 2010; Hart \& King, 2007), consider the community, where the practice is carried out, not only as a place to test skills or grasp data for research, but also as a recipient, a place where students can contribute to improving society, thanks to the mediation of disciplinary knowledge.

According to this vision, learning becomes a form of service, and service a form of learning.

Similar to problem-based learning practices, SL engages students in work that begins with the identification of problems, but instead of academic or hypothetical problems identified by teachers, the problems are real and are identified by communities (Connor-Greene, 2002); similar to the research-based learning approach, SL can be conducted like a scientific research experiment, but it can be designed to answer a relevant question proposed within the community, rather than being proposed in a textbook (Harkavy \& Hartley, 2010; DePrince, Priebe, \& Newton, 2011). According to this vision, the community is not considered as a 
laboratory for experiments, but as a partner to help and an opportunity, for students, to learn. Moreover, Eyler and Giles (1999) stress that "using the community as a laboratory rather than working with the community on jointly useful projects" is not only not an ethical action, but it can also have negative didactical consequences, as it "may stunt the development of partnerships that offer continuous benefits to both parties. It may also ironically make it more difficult to create situations for learners that facilitate learning, critical thinking, and perspective transformation" (p. 179).

Nevertheless, SL or CSL practices share with the experiential learning theory the idea that contact with communities exposes students to problems from real life that they could never have experienced in the classroom: this reality calls upon and challenges students' preconceptions, helping them to deconstruct and re-construct new visions about people, communities, and values, thanks to the virtuous circle between service and learning that can be built through research and reflection (Fleck, Hussey, \& Rutledge-Ellison, 2017, p. 232).

Therefore, we can affirm that SL experiences are forms of "laboratory of things in life" where the complexity of life is not forgotten in all its aspects: cognitive, social, emotional, relational, ethical, and political.

\section{Service Learning and Community Engagement Practices}

Service learning and community engagement practices have gradually transformed schools and universities in both North and South America, although with different connotations and philosophical references. They have also gradually been introduced throughout the rest of the world, including in Italy (Ubbiali, 2017).

The term service learning was first introduced in the literature by Robert Sigmon and William Ramsey to describe a project of the Oak Ridge Associated University in Tennessee in 1966; it then became more established in the 1980s (Stanton, Giles, \& Cruz, 1999).

While pedagogical attention to a possible link between service and learning began in the 1970s, political consideration of this theme found its public acknowledgement in the 1990s, when SL was quoted and sustained by federal laws, such as the National and Community Service Act (1990) and the National Service Trust Act (1993).

In Southern America, "aprendizaje-servicio soldiario," as SL is called, was born in school practice and was later theoretically developed and institutionalized in political acts (Tapia, 2010).

\section{How to Define Service Learning}

The value of SL was quickly recognized and consequently spread throughout many contexts that produced many practices and theorizations, making it difficult to find a unique definition of the concept (Furco, 2003). The multiplicity of definitions, if on one hand gives value to the richness of those practices that address different needs, on the other hand determines the scientific weakness of SL that, as an over-defined practice, is not a definite object. 
Already by 1990, Kendall and Associates (1990), through a systematic literature review, counted 147 definitions of SL, prompting them to propose a "clustering" of the collection into two macro-categories: SL as a pedagogy and SL as a philosophy. The definitions that present SL as a pedagogy underline its methodological aspects: SL as a teaching and learning method that has specific intentions, requires careful organization, and involves related instruments. The definitions that speak to SL as a philosophy propose it as a style, or a way of thinking about and orienting the practices of teaching and learning, without codifying practical aspects.

In the literature, the paper by Sigmon (1979), Service-Learning: Three Principles, is recognized as foundational. It is considered the first publication to define and systematize SL practices. The author presented the three principles that, as a framework, define SL pedagogy in his article as follows:

"Principle one: Those being served control the service(s) provided.

Principle two: Those being served become better able to serve and be served by their own actions.

Principle three: Those who serve also are learners and have significant control over what is expected to be learned." (Sigmon, 1979, p. 10)

Following the publication of Sigmon's paper, several subsequent definitions emerged. A good and influential one was cited in the United States public federal law National and Community Service Trust Act of 1993 (p. 59) (hereinafter referred to as $A c t$ ) as follows:

"The term "service-learning" means a method

A. under which students or participants learn and develop through active participation in thoughtfully organized service that

i. is conducted in and meets the needs of a community;

ii. is coordinated with an elementary school, secondary school, institution of higher education, or community service program, and with the community; and

B. that

iii. helps foster civic responsibility; and

i. is integrated into and enhances the academic curriculum of the students, or the educational components of the community service program in which the participants are enrolled; and

ii. provides structured time for the students or participants to reflect on the service experience."

In general, $\mathrm{SL}$ is defined as a method or a way to reach academic goals linked to the service (A) and learning (B) dimensions. From the service perspective, SL is characterized as adherent to real community needs and is coordinated by an educational institution that has a specific pedagogical mission, but always in connection to and cooperation with the community. The service has an educative aim, because it promotes civic engagement and a sense of responsibility in the students. Nevertheless, SL also represents an academic experience because it is 
part of a structured curriculum within schools and universities: it is an integrant part of the scholarly pathway, in that it contributes to reaching disciplinary and interdisciplinary aims typical of various curricula. As such, SL experiences enable students to put into action curricular content, knowledge, and abilities learned in their formal activities; moreover, they can learn by doing through the reflective activities that should occur after the actions in the field.

The Act underlines that the service has to be "thoughtfully organized"; it must be designed according to an explicit pedagogical intention and with a unitary vision of intent (mission, aims, and learning outcomes) within the curricula in which it is integrated.

Moreover, according to the Act, SL can also take place in community service programs, and not only in the formal ones. In fact, in the literature we can find research on such SL programs (Kackar-Cam \& Schmidt, 2014); most of the papers present projects developed in kindergartens, schools, colleges, universities, or post-graduate programs.

Different authors try to define SL in a more precise way, every one deepening different aspects of its practice or philosophy. Ehrilch (1996) observed the wide variety in SL practices but noted that all were rooted in the experiential learning concept presented by Dewey. "Service-learning is the various pedagogies that link community service and academic study so that each strengthens the other. The basic theory of service-learning is Dewey's: the interaction of knowledge and skills with experience is key to learning" (Ehrilch, 1996, p. xi).

Operational definitions of SL are also offered by some authors, such as Bringle, Hatcher, and McIntosh (2006), who are perhaps the most quoted:

"Service-learning is a course-based, credit-bearing educational experience in which students (a) participate in an organized service activity that meets identified community needs and (b) reflect on the service activity in such a way as to gain further understanding of course content, a broader appreciation of the discipline, and an enhanced sense of personal values and civic responsibility." (p. 12)

Service-learning experiences vary in typology and, according to Felten and Clayton (2011, p. 77) can "include short-term modules, semester-long activities, and multiyear as well as multicourse projects." The authors further noted that service action can be conceived as "direct or indirect, may involve low or high levels of responsibility, and may have a research component" (2011, p. 77). Even the term community can identify different contexts: the university campus, the local neighborhood, the nearby municipality, another state or country, or the online environment. "The term may refer to one or more partners, from small grassroots initiatives to large nonprofit or for-profit organizations" (Felten \& Clayton, 2011, p. 77).

Service-learning experiences vary in typology and can "include short-term modules, semester-long activities, and multiyear as well as multicourse projects." The service action can be conceived as "direct or indirect, may involve low or high levels of responsibility, and may have a research component." Even the term community can identify different contexts: the university campus, the local 
neighborhood, the nearby municipality, another state or country, or the online environment. "The term may refer to one or more partners, from small grassroots initiatives to large nonprofit or for profit organizations" (Felten \& Clayton, 2011, p. 77).

A brief retrospective looks at the story of SL can converge on some elements common to all visions and definitions. Service-learning experiences have to achieve the following:

"advance learning goals (academic and civic) and community purposes; involve reciprocal collaboration among students, faculty/staff, community members, community organizations, and educational institutions to fulfill shared objectives and build capacity among all partners; include critical reflection and assessment processes that are intentionally designed and facilitated to produce and document meaningful learning and service outcomes." (Felten \& Clayton, 2011, p. 76)

\section{A Balance between Service and Learning}

The curriculum of a formal academic institution is enriched and student learning is reinforced through the connection between academic and community aspects facilitated by service learning (Furco, 1996, p. 1); however, it is only when service and learning are designed and carried out as two dimensions in perfect equilibrium and reciprocal reinforcement that real SL is possible (Sigmon, 1994). Sigmon (1979) defined SL as a "reciprocal learning," including the idea that there is a balance between learning goals and service outcomes. This statement represents a critical instrument for evaluating SL projects. In fact, if the projects defined as SL are many, only those in which the two dimensions are balanced and reciprocally enhancing can be defined as proper SL activities. "Many programs do not fit this balanced model; instead the service may dwarf the learning, or the academic focus dominates" (Eyler \& Giles, 1999, p. 4).

The specificity of SL is its integration into the curriculum: different from other form of practice-based learning (such as cooperative learning, placement, education in the field, internship, and practical courses), SL is an educative experience that allows learning specific competences, typical of a course of study, together with civic and service engagement. Different from the extracurricular or after-school community service programs that are often proposed, SL has its power in being the framework of the curriculum: service actions in the community constitute real fieldwork that provokes learning processes.

Bringle and Hatcher (2009) proposed that the dimension of civic learning that is, more specifically, a civic engagement within a community characterizes SL.

Mendel-Reyes (1998) talked about the dimension of civic learning, referring to it as "democratic":

"Service learning as a pedagogy for citizenship integrates the academic study of democracy and the experience of democratic community service. The guiding principle behind the Democracy Project is that "the only truly 
effective education system for democracy is democracy-democratic action itself" (Mendel-Reyes, 1998, p. 38)

Multiple authors have asserted that SL activates growth in students' personal attributes (Jacoby, 1996; Lake \& Jones, 2008). In particular, it contributes to the development of attitudes and values in a more efficient way than other methodologies (Delve, Mintz, \& Stewart, 1990; Holsapple, 2012).

\section{Educational Aims}

Many studies have been carried out on the academic aims of SL (Conner \& Erickson, 2017). Authors point to various objectives, such as an increase in the sensitivity and empathic competence of participants (Bernacki \& Jaeger, 2008; Wilson, 2011), engagement in challenges dealing with social justice (Eppler, Ironsmith, Dingle, \& Erickson, 2011; Fenzel \& Dean, 2011; Simons et al., 2011), cultural and multicultural competences (Einfeld \& Collins, 2008; Meaney et al., 2008), and invalidating stereotypes (Conner, 2010; Meaney et al., 2008; Wright, Calabrese, \& Henry, 2009).

These goals are not generally achieved naturally; they are attained only by acting in a community or improvising SL activities. Research affirms that practices that are not carefully prepared and carried out with attention and an ongoing supervision, being occasional or too short in time, can result in outcomes that are opposite to the teachers' intentions. Indeed, if processes are not thoughtfully planned and supervised, stereotypes about groups or the community where the SL action is carried out can be reinforced (Erickson \& O'Connor, 2000; Erickson \& Santmire, 2001; Hollis, 2004; Jones, 2002; Kendall \& Ass., 1990; Sperling, 2007), or the will to engage in the common good can be weakened (Erickson \& O’Connor, 2000; Erickson \& Santmier, 2001; Houshmand et al., 2014).

\section{Kinds of Service Activities}

The practices of engagement in the community can be different; therefore, the kind of services that can be carried out and, consequently, the kind of learning achieved (curricular, personal, and civic) likewise are different.

Berger (2003) grouped SL practices into four categories of service: direct service, indirect service, advocacy, and research.

Direct service activities are those practices where the students and the community are engaged in a direct relationship. Examples include tutoring for younger children and service in senior centers or homeless shelters.

Indirect service takes place when the students are not engaged in a personal relationship, but in a service to the community considered as a whole. Taking care of a park and restoring public spaces are examples of indirect service activities.

Advocacy is the term that defines activities for which service consists of informational or awareness actions about a problem of public interest. Such activities include writing letters to citizens or politicians, participating in public conferences, and organizing committees. 
Service intended as research involves students in real research projects aimed at collecting and analyzing information related to problems of general interest, such as participating in studies or tests that will have an impact or disseminating such materials in the community.

\section{SL for Pre-service Teachers}

\section{Education of Educators: SL and Teacher Training}

If we want the ethics of service and civic engagement to spread throughout society and to facilitate the spirit of common living, we must invest in our schools. The education of educators, or teachers' training, is central to providing a good ethical experience to future generations. In fact, it is necessary that the teachers are also community engaged, able to act for a community and take on the role of actors of transformation and of social justice. Teachers, in fact, are practitioners, specifically, people who are asked to care about nourishing others in all their capabilities and to contribute to the care of the community they live in. Working with people who put care in action requires action of care, too. To educate teachers in SL involves ensuring that they become good caregivers.

Keith (2016) presented a vision of training for practitioners that she called "cultivation": a practice that is an action of care for people, "an organic process that involves a collaboration with nature - here, the gifts and qualities of practitioners" (p. 1), where the focus is not on a 'transformative learning', but on a "transformative practice" (p. 15). Practice deals with contextual factors, such as "language and forms of speaking, tools, and material objects (including bodies), as well as ways of relating and exercising power, solidarity, authority, and privilege" (Keith, 2016, p. 2). Kemmis and colleagues (2014) referred to those concepts as "sayings, doings, and relating." Starting from this idea, "the actions of practitioners emerge from the interrelatedness of all aspects - present and historical, experiential and structural, individual and group-based - that enter into a given situation in which they are involved" (Keith, 2016, p. 2). Practice is not only acting, but it is also building a common language able to give voice to the sense of action, of relationships between people and the context, between people and their learning, and between different kinds of learning and of personal aspects that are involved in action.

Good practitioners look for the good, acting with wisdom. Good didactive practitioners are able to design and carry out educational pathways starting from their analysis of the context and its history, of the elements and people involved, and of their future intentions and directions. Using their wisdom, academic practitioners are able to identify challenges in contexts and, through their virtuous habits, act with learners to orient them in looking for the good, actually for the common good.

Therefore, a serious and deep rethinking is even more important for the university that aims to educate practitioners, in particular, through pre-service teacher courses. Since the 1990s, SL has been a pedagogical model that has been 
applied in teacher education courses: in fact, in the literature we can find many guides offering examples of programs that combine courses and fieldwork according to the SL perspective (Erickson \& Anderson, 1997; Meidi \& Dowell, 2018), as well as scientific papers presenting them (Hallman \& Burdick, 2011; Hart \& King, 2007; He \& Prater, 2014; Root, 1997; Ryan \& Healy, 2009; Seban, 2013). By 2003, Anderson and Erickson (2003) counted more than 300 teacher training programs integrating SL in the curriculum.

In his literature review, Anderson (1998, p. 3) noted that the most often cited reasons argued by teacher educators for integrating SL into their courses are the following:

1. "To prepare new teachers to use service-learning as a teaching method with their K-12 students;

2. To help socialize teachers in the essential moral and civic obligations of teaching, including teaching with "care", fostering life-long civic engagement, adapting to the needs of learners with diverse and special needs, and having a commitment to advocate for social justice for children and families;

3. To enhance preservice teachers' ability to reflect critically on current educational practices and their own teaching;

4. To develop in preservice teachers the dispositions and abilities needed to easily and fully adopt other educational reforms such as authentic assessment, teaching with integrated thematic units, focusing on higher order thinking skills, and making improvements in school schedules and climate;

5. To accelerate the process of learning how to perform a variety of roles needed to meet the needs of students such as counselor, community liaison, advocate, and moral leader; and

6. To develop human service-oriented teachers who can work effectively in schools with integrated services or other social service settings."

It is interesting to point out that since this SL project is set in a course for future teachers, it has a double responsibility, one for pre-service teachers and the other for their future pupils: a sort of "education to education" to ethics and civic engagement.

Research on SL shows how it is useful to achieve multiple educational goals addressing several dimensions: cognitive, social, emotional, professional, and civic engagement (Baldwin, Buchanan, \& Rudisill, 2007; Carson \& Domangue, 2013; Conner, 2010; Cooper, 2007; Hale, 2008; Jones \& Hill, 2001; Lake \& Jones, 2008; Myers-Lipton, 1996; Theriot, 2006). In particular, SL aims at important learning outcomes for teachers: a deeper comprehension of society (Kahne \& Westheimer, 1996), the deconstruction of stereotypes and stigmas (Baldwin et al., 2007; Barton, 2000), attention towards students with different cultural backgrounds or coming from disadvantaged areas (Hunt, 2007; Carrington \& Saggers, 2008), the education of pupils with special needs (Russell, 2007), the building of learning communities between pre-service and in-service teachers and the community (Swick, 2001), and awareness of social justice problems in society 
(Donahue, 1998; Stamopoulos, 2006). Wade (1997, p. 185-186) argued that SL is particularly suitable in teachers training because: it provides pre-service teachers with opportunities to practice reflection, therefore being able to educate their pupils to do the same; it fosters a student-centered and caring approach to teaching (in fact, also the service experience is beneficiary-centered); it develops a more complex vision of the teaching and learning practice enhancing creativity and the searching for resources in communities to develop educational projects (in fact, SL has to face the complexity of reality that cannot be learned in textbooks); and it provides pre-service teachers with the skills to develop autonomy in their teaching.

\section{The University of Verona Project: A Community Research Service Learning for Pre-service Teachers}

At the University of Verona (Italy), in the combined bachelor's and master's degree program for primary school education, for the past five years we have been proposing a community service learning project as a curricular training program that pre-service teachers have to carry out in their curriculum (Mortari, 2017; Mortari, Silva, Girelli, \& Ubbiali, 2017). Our choice is motivated by a philosophical view of education, as previously described, as well as by a desire to respond to the call coming from educational (academic and school) contexts of the Italian community we live in. In particular, it is urgent to orient the students' educational processes in order to prepare them to meet the complexity of the real school world; to welcome the distress signals from the school that has to face new educational challenges and where teachers often feel alone and weaponless; and to re-think the University role, as an actor able to be engaged in serving the community (Mortari \& Ubbiali, 2017).

To face these urgencies, we designed and are carrying out a training model in which the needs, requests, sources, and competences of every actor interact, in order to give form to a "common good" that represents an answer for the benefit of students, faculties, schoolteachers and, eventually, schoolchildren. In this vision, student learning occurs within a service activity (towards the school, i.e., teachers' requests, and, as a consequence, children's learning) thanks to the reflective mediation of the community of practitioners (school teachers) and the supervision of the university (the faculties) that accompany them in the research process, activating a reflective posture towards their service experience.

The project of the Laboratory LeCoSe (Learning Community Service) is a Community Service Learning experience in which pre-service teachers are engaged in helping in-service teachers in their everyday educational job: this action represents curricular training for the university students and is the place where they design and improve research that represents the basis for their dissertation.

At a political level, the University assumes the SL project as the peculiarity for the pre-service obligatory training in schools. When students engage in schools, they meet the teachers who will become their mentors in order to identify the mentors' specific needs (or desires) related to the problems or challenges of everyday life at school. This action is a real form of research because students 
have to interview their mentors, analyze their words, and observe their class dynamics using qualitative instruments.

After defining the educative need/desire together, and with the supervision of the academic team, students plan the interview in agreement with teachers and then perform their service in the schools. Moreover, students are invited to carry out qualitative research on their service action: this is one of the unique aspects of our project that authenticates it as community research service learning. From the point of view of service, students help in-service teachers in their professional lives. From the point of view of learning, students learn the job from an "elder" and more expert teacher, and learn to become a "practical researcher": in accordance with the European Union indications $(2013,2014)$ we are convinced that the research competence is fundamental for a good teacher.

All these dimensions are lived within a community context, made of children, in-service teachers, pre-service teachers, and academic teams.

Our project consists of six phases:

1. Period for class observation, familiarization with the context, and identification of the needs of the class and teacher: using a qualitative approach, students observe the class dynamics and interview teachers in order to identify and describe a need or a desire with which they would like to be helped. The analysis of this request is then discussed and shared with the university team, so that the problem/desire can be analyzed from different perspectives;

2. Literature review: students look for contributions in the literature about the identified need and the project to design;

3. Design of an educational project: in order to address the identified need, teachers and students plan an intervention and define both actions and roles;

4. Service action: after an appropriate preparation and sharing with the teachers, the students perform their project together with the teachers;

5. Realization of research related to their educational project: during the service actions in the class, students carry out educative research (Mortari, 2009), useful for the practice (Rorty, 1993), collecting qualitative data and analyzing them within a methodological framework built together with the academic team;

6. Writing of the dissertation that collects the documentation of the SL project with the analysis of the need and of the school context, the research report and the reflection on the SL experience useful for orienting the future teaching practice.

During the whole process, students are asked to nurture their reflective competence. In order to transform their action into a real educative training, students are supervised by the University team that involves them in common group reflections and asks them to keep a reflective journal in which they are required to write about not only what is happening in the pedagogical relationship, but also about their thoughts and feelings (reflective journal).

Since every class is different and has its own characteristics, and every teacher has his or her own sensibility, every expressed need is different. In consequence, 
every educational path is different. Students are, consequently, involved in different actions: operational projects, where students are asked to concretely help their mentor with a specific project during the class lessons; indirect service, where students are asked to make a critical analysis of the teacher's practice through accurate documentation about it or through research focusing on the teacher's pedagogical actions; design project, where teachers ask students and faculties to help in identifying new educative strategies in order to face very complex situations.

Our SL is also designed as a research experience, an empirical pedagogical research (Mortari, 2003, 2009) that we call service research (Mortari, 2003, 2017), which is research useful for teachers to improve their competences and capacity to read (and try to solve) their classes' needs and challenges. All pre-service teachers during their training carry out qualitative research, collecting and analyzing data from the class with which they are involved. Every situation has its own need and, consequently, a related research question that allows the student to understand something more of the class, the efficacy of the project carried out, and the learning of pupils. All the research reports are addressed to in-service teachers (mentors), who can use the findings in order to re-plan their educative activities or to reframe relationships with pupils.

In summary, the Community Research Service Learning experience at the University of Verona is a practice where service, learning, research, and creation of the community are strictly related and circularly involved and strengthened. As depicted in Figure 1, we can summarize the dimensions of the project as follows:

a. Service: students perform a service to address a real school need or teacher's desire;

b. Learning: students learn from their expert mentor;

c. Research: students collect and analyze data during the service learning experience;

d. Learning: students develop a research competence;

e. Further service: the school receives the results and reflections of the "service research" that can be used for further improvement of future actions.

All these dimensions are nurtured by reflection and, step by step, build a real community between school and university, giving form to an effective political vision of education as depicted in Figure 1. 
Figure 1. A Schematic Synthesis of Laboratory LeCoSe

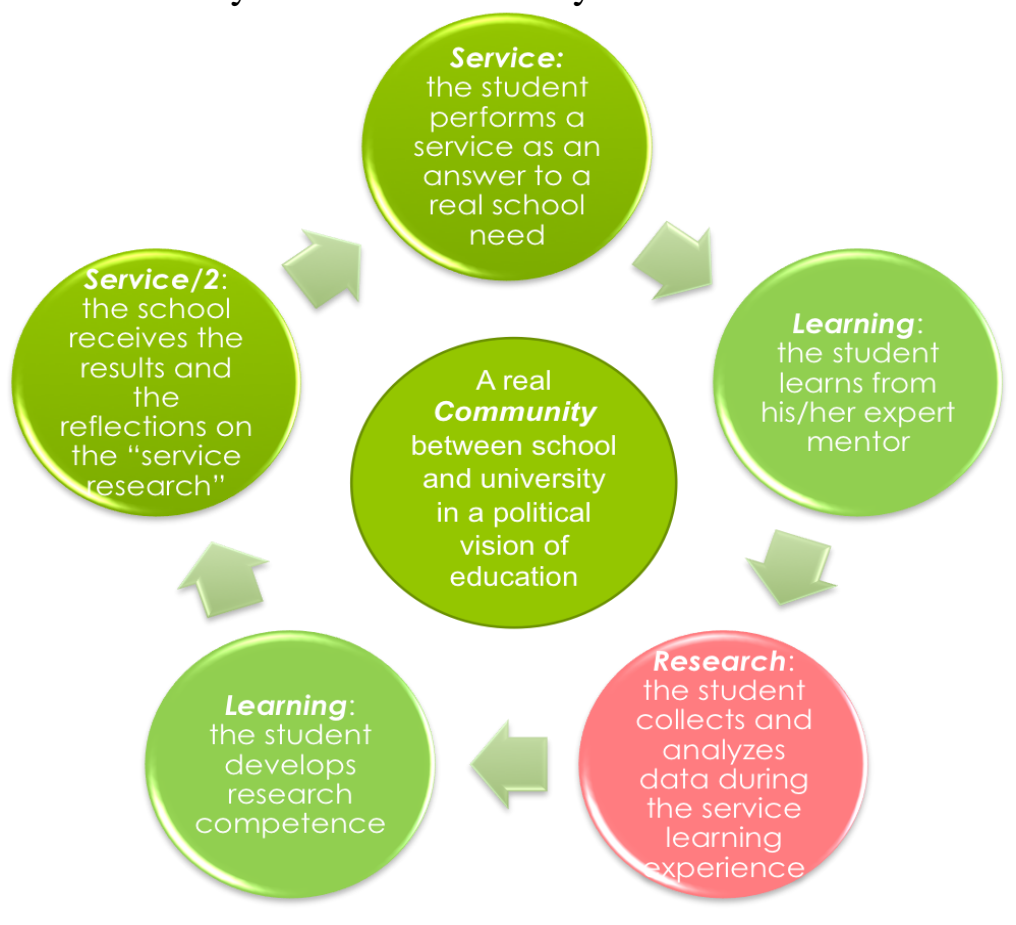

\section{Conclusions}

As a result of empirical and theoretical research, we can affirm that SL is a practice that has the strength to reframe higher education, orienting its practice to educate to a habit that represents a revolutionary democratic education able to give form to a new society, based on the principle of solidarity.

The SL project of the University of Verona (Italy) is constantly subject to research. In order to collect the point of view of pre-service teachers involved, we asked a sample of 45 students to write a reflective text explicating what they believed they learned through their SL experience. A qualitative analysis, carried out through a "phenomenological-grounded" method (Mortari, 2007), which is a method that interconnects the empirical phenomenological method (Giorgi, 1985) and grounded theory (Glaser \& Strauss, 1967), indicated that pre-service teachers believed they gained professional knowledge and skills (completion of professional profile; reflective skills; research skills; development of a service perspective), "transversal" or "personal" skills (how to learn from mistakes and manage a crisis; how to handle the unexpected; self-critical skills; supporting motivation), and inter-relational skills (collaborative skills; empathic listening; a child-centered approach) (Mortari, Silva, \& Ubbiali, 2019). These findings show that SL is significant for the cultivation of teachers as good practitioners, but also as good persons and good members of community.

We are carrying out other studies, in particular, one examining the capacity of reflection growing out of the SL experience through the analysis of students' reflective journals. Other interesting data collected and subject to another upcoming study are the voices of in-service teachers that, as mentors, help and are 
helped by our students. From these stakeholders' own words, we can clearly collect satisfaction and feelings of real help and improvement of the pupils' experiences. Pre-service teachers are able to improve their academic practices, and their research helps in-service teachers to better understand their pupils and design new activities.

Data show the efficacy of the SL project in developing university students as practitioners (developing their professional competences), as people (helping them to "flourish" in important personal and interpersonal aspects), and as citizens (developing their community consciousness). Data also show the efficacy of students' activities in the educational context, that is, in the community that receives the SL experience, where people and community grow together. This demonstrates the political valence of SL: the community is strengthened, and also the mission of the University and its relationship with the community are strengthened. The University becomes an actor in the community, and the school feels co-responsible for educating pre-service teachers. Together we are putting in action the principle of care, which involves not only individuals, but institutions as well. As Ricoeur (1992, p. 172) stated, people and institutions are linked together in realizing an ethical life, since ethics is "aiming at a good life lived with and for others in just institutions." This "aiming" is not only a form of desire, but it becomes a real action that assumes the form of care: for the self, for the other, and for institutions (Ricoeur, 1990).

Care, in fact, is essential for every human being, because without care no one can flourish in his or her own existential potentialities and directions, in relationships with others, or in common research for the common good.

In fact, when care goes beyond the face-to-face relationship and reaches a world dimension and a feeling for the ethical necessity to care for a good institution able to govern it, policy takes form. Policy is a service to the world that is nurtured by continuous learning and transforms knowledge in action in order to give form to a better coexistence: a real service that becomes learning and a learning that becomes service.

\section{References}

Anderson, J. (1998). Service-learning and teacher education. ERIC Clearinghouse on Teaching and Teacher Education Washington DC. ERIC Document No. 421481. www.eric.ed.gov.

Anderson, J.B., \& Erickson, J.A. (2003). Service-learning in pre-service teacher education. Academic Exchange Quarterly, 7(2), 111-115.

Arendt, H. (1958). The human condition. Chicago, IL: University of Chicago Press.

Aristotle (2011). Nicomachean Ethics. Trans. Bartlett, R. C.; and Collins, S. D. Chicago, IL: University of Chicago Press.

Baldwin, S., Buchanan, A., \& Rudisill, M. (2007). What teacher candidates learned about diversity, social justice, and themselves from Service Learning experiences. Journal of Teacher Education, 58(4), 315-327.

Barton, A.C. (2000). Crafting multicultural science education with pre-service teachers through service learning. Journal of Curriculum Studies, 32(6), 797-820. 
Bauman, Z. (1999). In search of politics. Cambridge: Polity Press.

Bauman, Z. (2001). The individualized society. Cambridge: Polity Press.

Bauman, Z. (2004). Wasted lives: modernity and its outcasts. Cambridge: Polity.

Beck, U. (1998). World risk society. Cambridge: Polity Press.

Berger, K.C. (2003). The complete guide to Service Learning. Proven, practical ways to engage students in civic responsibility, academic curriculum, \& social action. Minneapolis, MN: Free Spirit Publishing.

Bernacki, M.L., \& Jaeger, E. (2008). Exploring the impact of service- learning on moral development and moral orientation. Michigan Journal of Community Service Learning, 14(2), 5-15.

Boella, L. (2006). Sentire l'altro. Conoscere e praticare l'empatia. Milano: Raffaello Cortina.

Boella, L. (2018). Empatie. L'esperienza empatica nella società del conflitto. Milano: Raffaello Cortina.

Bringle, R., \& Hatcher, J. (2009). Innovative practices in service-learning and curricular engagement. New Directions for Higher Education, 147, 37-46.

Bringle, R., Hatcher, J., \& McIntosh, R. (2006). Analyzing Morton's typology of service paradigms and integrity. Michigan Journal of Community Service Learning, 13, 515.

Carrington, S., \& Saggers, B. (2008). Service-learning informing the development of an inclusive ethical framework for beginning teachers. Teaching and Teacher Education, 24(3), 795-806.

Carson, R.L., \& Domangue, E.A. (2013). The emotional component of Service Learning. Journal of Experiential Education, 36(2), 139-154.

Conner, J.O. (2010). Learning to unlearn: how a Service Learning project can help teacher candidates to reframe urban students. Teacher and Teaching Education, 26(5), 11701177.

Conner, J., \& Erickson, J. (2017). When does Service-learning work? Contact theory and Service-Learning Courses in Higher education. Michigan Journal of Community Service Learning, 23(2), 53-65.

Connor-Grrene P. (2002). Problem based service learning: The evolution of a team project. Teaching of Psychology, 29(3), 193-197.

Cooper, J. (2007). Strengthening the case for community-based learning in teacher education. Journal of Teacher Education, 58(3), 245-255.

Delve, C., Mintz, S., \& Stewart, G. (1990). Community service as values education. San Francisco, CA: JosseyBass.

DePrince, A.P., Priebe S.J., \& Newton, T. (2011). Learning about violence against women in research methods: A comparison to traditional pedagogy. Psychological trauma; Theory, research, practice and policy, 3(3), 215-222.

Dewey, J. (1916). Democracy and Education: An Introduction to the Philosophy of Education. New York, NY: Macmillan.

Dewey, J. (1938). Experience and Education. (Kappa Delta Pi Lecture Series). New York, NY: Collier Books.

Donahaue, D.M. (1998). Service-learning for preservice teachers: ethical dilemmas for practice. Teaching and Teacher Education, 15(1999), 685-695.

Ehrlich, T. (1996). Foreword. In B. Jacoby \& Ass., Service-Learning in Higher Education: Concepts and Practices (pp. xi-xii). San Francisco, CA: Jossey-Bass.

Einfeld, A., \& Collins, D. (2008). The relationships between service- learning, social justice, multicultural competence, and civic engagement. Journal of College Student Development, 49(2), 95- 109. 
Eppler, M.A., Ironsmith, M., Dingle, S.H., \& Errickson, M.A. (2011). Benefits of servicelearning for freshmen college students and elementary school children. Journal of the Scholarship of Teaching and Learning, 11(4), 102- 115.

Erickson, J. A., \& Anderson, J. B. (1997). Learning with the community: Concepts and models for service-learning in teacher education. Sterling (VA): Stylus Publishing.

Erickson, J., \& O'Connor, S. (2000). Service-learning's effect on prejudice: does it reduce or promote it? In C. O'Grady (Ed.), Transforming education, transforming the world: The integration of service-learning and multicultural education into higher education (pp. 59-70). Mahwah, NJ: Erlbaum.

Erickson, J., \& Santmire, T. (2001). Psychological bases of effective service- learning. In J. Anderson, K. Swick, \& J. Yff (Eds.), Strengthening service and learning in teacher education. Washington, DC: American Association of Colleges for Teacher Education and the ERIC Clearinghouse for Teaching and Teacher Education.

European Commission (2014). Initial teacher education in Europe: an overview of policy issues. Retrieved from https://bit.ly/2SOgIle.

European Commission, EACEA, Eurydice (2013). Key data on teachers and school leaders in Europe. 2013 Edition. Eurydice Report. Luxembourg, LU: Publications Office of the European Union.

Eyler, J., \& Giles, D. (1999). Where's the learning in Service Learning?. San Francisco, CA: Jossey-Bass.

Felten, P., \& Clayton, P.H. (2011). Service-Learning. New directions for teaching and learning, 128, 75-84.

Fenzel, L.M., \& Dean, R. (2011). Changes in students' social justice and racial attitudes in an undergraduate child psychology service-learning course. Journal of Research on Service Learning \& Teacher Education, 1(2), 20-30.

Fleck, B., Hussey, H.D., \& Rutledge-Ellison, L. (2017). Linking class and community: An investigation of service learning. Teaching of Psychology, 44(3), 232-239.

Furco, A., \& Root, S. (2010). Research Demonstrates the Value of Service Learning. Phi Delta Kappan, 91(5), 16-20.

Furco, A. (1996). Service Learning: a balanced approach to experiential education. In B. Taylor (ed.), Expanding boundaries: Service and Learning (pp. 2-6). Washington, DC: Corporation for National Service.

Furco, A. (2003). Issues of definition and program diversity in the study of servicelearning. In S. H. Billig \& A. S. Waterman (Eds.), Studying service-learning: Innovations in education research methodology (pp. 13-34). Mahwah, NJ: Erlbaum.

Giorgi, A. (1985). Phenomenological and Psychological Research. Pittsburgh: Duquesne University Press.

Glaser, B. \& Strauss, A. (1967). The Discovery of Grounded Theory. Strategies for qualitative research. Chicago: Aldine.

Hale, A. (2008). Service Learning with Latino communities: effects on pre-service teachers. Journal of Hispanic Higher Education, 7(1), 54-69.

Hallman, H.L., \& Burdick, M.N. (2011). Service Learning and the preparation of English teacher. English Education, 43(4), 341-368.

Harkavy, I., \& Hartley, M. (2010). Pursuing Franklin's dream: Philosophical and historical roots of service learning. American Journal of Psychology, 46(3-4), 418-427.

Hart, M., \& King, J.R. (2007). Service Learning and literacy tutoring: academic impact on pre-service teachers. Teaching and Teacher Education, 23(4), 323-338.

He, Y., \& Prater, K. (2014). Writing together, learning together: teacher development through community Service Learning. Teachers and Teaching: theory and practice, $20(1), 32-44$. 
Hollis, S. (2004). Blaming me, blaming you: Assessing service learning and participants' tendency to blame the victim. Sociological Spectrum, 24(5), 575- 600.

Holsapple, M. A. (2012). Service- learning and student diversity outcomes: Existing evidence and directions for future research. Michigan Journal of Community Service Learning, 18(2), 5- 18.

Houshmand, S., Spanierman, L. B., Beer, A. M., Poteat, P. V., \& Lawson, L. J. (2014). The impact of a servicelearning design course on white students' racial attitudes. Journal of Higher Education Outreach and Engagement, 18(2), 19- 48.

Hunt, R. (2007). Service-learning: An eye-opening experience that provokes emotion and challenges stereotypes. Journal of Nursing Education, 46(6), 277-281.

Jacoby, B. (1996). Service-learning in today's higher education. In: B. Jacoby \& Associates (Eds.), Service-learning in higher education: Concepts and Practices (pp. 3-25). San Francisco, CA: Jossey-Bass.

Jones, S. (2002). The underside of service learning. About Campus, 7(4), 10- 15.

Jones, S.R., \& Hill, K. (2001). Crossing high street: understanding diversity through community Service Learning. Journal of College Student Development, 42(3), 204216.

Kackar-Cam, H., \& Schmidt, J.A. (2014). Community-based Service-learning as a context for youth autonomy, competence and relatedness. The High School Journal, 98(1), 83-108.

Kahne, J., \& Westheimer, J. (1996). In the service of what? The politics of service learning. Phi Delta Kappan, 77(9), 593-599.

Keith N.Z. (2016). Cultivating Practitioners of Democratic Civic Engagement. Michigan Journal of Community Service Learning, 23(1), 15-36.

Kemmis, S., Wilkinson, J., Edwards- Groves, C., Hardy, I., Grootenboer, P., \& Bristol, L. (2014). Changing practices, changing education. Singapore: Springer Science+ Business Media.

Kendall, J.C., \& Ass. (eds.). (1990). Combining service and learning: a resource book for community and public service, Vol. II. Raleigh, NC: National Society for Internships and Experiential Education.

Kielsmeier, J.C. (2010). Build a bridge between service and learning. Phi Delta Kappan International, 91(5), 8-15.

Kolb, D.A. (1984). Experiential learning: experience as the source of learning and development. Englewood Cliffs, NJ: Prentice Hall.

Lake, V.E., \& Jones, I. (2008). Service-Learning in early childhood teacher education: using service to put meaning back into learning. Teacher and Teaching Education, 24(8), 2146-2156.

Lévinas, E. (1961). Totalité et infini. La Haye: Nijhoff.

Luhmann, N. (1984). Soziale Systeme. Grundriß einer allgemeinen Theorie. Frankfurt am Main: Suhrkamp.

Marullo, S., \& Edwards, B. (2000). From charity to justice: The potential of universitycommunity collaboration for social change. American Behavioral Scientist, 43(5), 895-912.

Maturana, H. R., and Varela, F. G., (1980). Autopoiesis and Cognition. Dordrecht, Netherlands: Reidel.

Meaney, K.S., Bohler, H.R., Kopf, K., Hernandez, L., \& Scott, LT.S. (2008). ServiceLearning and pre-service educators' cultural competence for teaching: An exploratory study. Journal of Experiential Education, 31(2), 189-208.

Meidi, T.D., \& Dowell M.M.S. (Eds.) (2018). Handbook of Research on Service-Learning Initiatives in Teacher Education Program. Hershey, PA: IGI Global. 
Mendel-Reyes, M., (1998). A pedagogy for citizenship: service learning and democratic education. New Directions for Students Services, 73, 31-38.

Morin, E. (1994). Mes demon. Paris: Stock.

Morin, E. (2007). Vers L'abîme. Paris: L'Herme.

Mortari, L. (2003). Apprendere dall'esperienza. Il pensare riflessivo nella formazione. Roma: Carocci.

Mortari, L. (2007). Cultura della ricerca e pedagogia. Prospettive epistemologiche. Roma: Carocci.

Mortari, L. (2009). Ricercare e riflettere. La formazione del docente professionista. Roma: Carocci.

Mortari, L. (2015). Filosofia della cura. Milano: Cortina.

Mortari, L. (2017). Costruire insieme un bene comune. In L. Mortari (ed.), Service Learning. Per un apprendimento responsabile (pp. 9-33). Milano: FrancoAngeli.

Mortari, L., \& Saiani, L. (Eds.) (2014). Gestures and thoughts of caring. New York, NY Boston, MA: McGraw-Hill Education.

Mortari, L., \& Ubbiali, M. (2017). Community Service Learning: An Ethical Proposal for Teacher Education. TOJET: The Turkish Online Journal Of Educational Technology, Special Issue for INTE 2017 - October 2017, pp. 571-581.

Mortari, L., Silva, R., Girelli, C., \& Ubbiali, M. (2017). Rethinking Apprenticeship in PreService Teachers' Training. Journal of Education and Human Development, 6(2), 76-85.

Mortari L., Silva R., \& Ubbiali M. (2019). A case of Service Learning and Research Engagement in pre-service teachers' education. In Journal of Higher Education Outreach and Engagement, 23(3), 145-158.

Murdoch, I. (1970). The Sovereignty of Good. London: Routledge.

Myers-Lipton, S.J. (1996). Effect of a comprehensive Service-Learning program on college students' level of modern racism. Michigan Journal of Community Service Learning, 3(1), 44-54.

Nancy, J.L. (1996). Etre singulier pluriel. Paris: Galilée.

Noddings, N. (1984). Caring. Berkeley, CA: University of California Press.

Noddings, N. (1992). The Challenge to Care in School. An Alternative Approach to Education. New York, NY: Teachers' College Press.

Plato (1871). The dialogues of Plato. Trans. B. Jowett. Oxford: Clarendon press.

Public Law 21 settembre 1993, n. 103-82, National and Community Service Trust Act. Retrieved from https://bit.ly/382h6oC.

Public Law $21^{\text {st }}$ September 1993, n. 103-82, National and Community Service Trust Act. Retrieved from https://bit.ly/3bd1NM8.

Pulcini, E. (2009). La cura del mondo. Paura e responsabilità nell'età globale. Torino: Bollati Boringhieri.

Ricoeur, P. (1990). Ethique et morale. Revue de l'Institut catholique de Paris, 34, avriljuin, pp. 131-142.

Ricoeur, P. (1992). Oneself as Another. Chicago, IL: University of Chicago Press,.

Root, S.C. (1997). School based service: a review of research for teacher educators. In J.A. Erickson \& F.B. Anderson (eds.), Learning with the community: concepts and models for Service Learning in teacher education (pp. 42-72). Washington, DC: American Association for Colleges of Teacher Education.

Russell, N.M. (2007). Teaching more than English: Connecting ESL students to their community through service learning. Phi Delta Kappa, 88(10), 770-771.

Ryan, M., \& Healy, A. (2009). It's not all about school: ways of disrupting pre-service teachers' perceptions of pedagogy and communication. Teaching and Teacher Education, 25(3), 424-429. 
Seban, D. (2013). The impact of the type of projects on preservice teachers' conceptualization of Service Learning. Teaching and Teacher Education, 32, 87-97.

Sigmon R.L. (1994). Linking service with learning. Washington, DC: Council of Independent Colleges.

Sigmon, R.L. (1979). Service-learning: Three Principles. Synergist. National Center for Service-Learning, ACTION, 8(1), 9-11.

Simons, L., Fehr, L., Hogerwerff, f., Blank, N., Georganas, D., \& Russell, B. (2011). The application of racial identity development in academic-based service learning. International. Journal of Teaching and Learning in Higher Education, 23(1), $72-83$.

Sperling, R. (2007). Service-learning as a method of teaching multiculturalism to White college students. Journal of Latinos and Education, 6(4), 209-322.

Stamopoulos, E. (2006). Empowering pre-service teachers to embrace diversity. Australian Journal of Early Childhood Education, 31(4), 30-39.

Stanton, T., Giles, D. \& Cruz, N. (1999). Service-learning: A movement's pioneers reflect on its origins, practice, and future. San Francisco, CA: Jossey-Bass.

Swick, K.J. (2001), Service-learning in teacher education: building learning communities. The Clearing House, 74(5), 261-264.

Tapia, M.N. (2010). Service learning widespread in Latin America. The Phi Delta Kappan, 91(5), 31-32.

Theriot, S. (2006). Perceived benefits of Service Learning in teacher education. Issues in Educational Research, 16(2), 241-252.

Ubbiali, M. (2017). Il service learning: un'analisi sistematica della letteratura. In L. Mortari (ed.), Service Learning. Per un apprendimento responsabile (pp. 71-215). Milano: FrancoAngeli.

UN General Assembly (2015). Transforming our world: the 2030 Agenda for Sustainable Development, 21 October 2015, A/RES/70/1. Retrieved from https://bit.ly/3bcfScz.

Wade, R. (1997). Empowerment in student teaching through community service learning. Theory into Practice, 36(3), 184-191.

Wilson, J.C. (2011). Service-learning and the development of empathy in U.S. college students. Education \& Training, 53(2/3), 207- 217.

Wright, A., Calabrese, N., \& Henry, J. (2009). How service and learning came together to promote "cura personalis". International Journal of Teaching and Learning in Higher Education, 20(2), 274- 283. 



\title{
Early Childhood Education and Instructional Ecology: A Vygotskian Approach in Teaching Early Childhood Social Studies
}

\author{
By Kwabena Ofori-Attah ${ }^{*}$
}

\begin{abstract}
This study guided by Vygotsky's Zone of Proximal Development (ZPD) theory explored the perception of pre-service teachers about the application of the ZPD in the classroom. Five participants, all junior students, were purposefully selected from a university in the southern region of the United States to participate in the study. Open-ended interview questions were designed from a review of the literature regarding the effectiveness of Vygotsky's ZPD in the classroom. Axial coding was used to analyze the data for the final research report. A major finding from the study is that Vygotsky's ZPD is recognized by Educator Preparatory Providers (EPPS) as a major instructional approach used to promote student achievement and that some pre-educator candidates perceive problems implementing this innovative form of teaching social studies in the early childhood classroom. Another significant finding from the study is that it extends our knowledge about the application of Vygotsky's ZPD in the early childhood social studies classroom. Implications for early childhood teacher preparation and future research are considered in the paper.
\end{abstract}

Keywords: cognitive development, early childhood education, instructional ecology, preservice teachers, zone of proximal development

\section{Background of the Study}

The education of children during the early years of learning, from birth to age five, within the appropriate instructional ecology has attracted the attention of educators in recent years. A trend that started slowly during the middle ages has now become a top agenda in perhaps many sectors of teacher education programs. All educator preparation providers (EPPs) are expected by accreditation agencies such as the Council for the Accreditation of Teacher Preparation (CAEP) to prepare teachers who have the content, pedagogical and professional knowledge to be effective teachers in the classroom (Essa, 2011; Snowman \& McCown, 2015).

Dating back to antiquity, most parents did not neglect the education of their children. For instance, the ancient Greeks, Romans, Egyptians, Chinese, Indians, all paid attention to the education of young children. The ancient Greeks saw human development as a transformation from an imperfect state of childhood to the ideal adulthood (Essa, 2011). Therefore, they had education systems for both boys and girls (Essa, 2011). The ancient Romans set up schools called ludi to educate young children, especially boys. Other ancient societies paid more attention to the education of young boys more than the education of young girls.

\footnotetext{
*Associate Professor of Education, Central State University, USA.
} 
Young girls had their education essentially at home (Kaplan, \& Owings, 2011; Ornstein \& Levine, 2006). These observations clearly indicate that the education of young children in ancient societies attracted the attention of educational planners.

In colonial America, teachers employed to teach young children had little or no training in pedagogical skills. The instructional ecology was ill-planned and delivered. Essentially, the teachers taught the way they were taught when they were young children in school. In the classroom, these untrained teachers relied on their own effort and thinking skills to teach these young children. Such practices denied many young children the opportunity to academically develop to their fullest potential. Today, the education of young children has attracted the attention of educational planners and so teachers who plan to teach young children in the United States of America must attend college to earn a teaching certificate before being employed to teach young children in the public schools (Essa, 2011; Morrison, 2012; Slavin, 2015).

Apart from training early childhood teacher candidates on how to acquire pedagogical skills, educator preparation institutions provide these teacher candidates intellectual groundings and foundations in the content areas (Fritzer, \& Brewer, 2010). To be specific, the traditional social studies curriculum at the kindergarten grade level focuses on content that teaches about groups of people in terms of current affairs, economics, geography, history, international and global issues (Farris, 2015; Sanchez, 2010; Seefeldt, Castle, \& Falconer, 2014; Zarrillo, 2012).

\section{Problem Statement}

Instructional ecology is an essential part of pedagogy. It is important for teachers to master instructional ecology because it forms the foundation for effective teaching. Instructional ecology is the relationship between students and their instructional environment (Ysseldyke, 2004). As Ysseldyke (2004, p. 2080) argues, "Students' behavior and academic performance are influenced by the environment in which they are taught." Because of this argument, all educator preparation programs include pedagogical strategies that are based on sound educational theories, principles, or models (Seefeldt, Castle, \& Falconer 2014; Shabani, 2016). For more than 100 years, psychologists have developed methods for teaching and learning and, within the past few decades, have focused significant attention on studying educationally relevant theories and aspects of learning with the sole aim of improving student learning (Larson \& Keiper, 2011; Mayer, 2003; Tuckman \& Monetti, 2013). Some of the common educational theories covered in teacher education programs include behaviorism, cognitive psychology, social cognitive learning, human development, or Vygotsky's Zone of Proximal Development (ZPD). The ZPD is the gap between the child's independent performance and the child's assisted performance from and an adult or a more expert peer (Schickedanz, Schickedanz, Forsyth, \& Forsyth, 2001). All these theories embody elements of instructional ecology. Consequently, all teacher 
candidates study these theories during their training (Shabani, 2016). They study these theories during their pedagogical courses. However, some teacher candidates in the early childhood education program anticipate encountering problems implementing Vygotsky's ZPD in their teaching after graduation. Despite an increased interest in the integration of educational theories and the appropriate instructional ecology in the preparation of teacher candidates by educator preparation providers (EPPs), there are currently no empirical studies on how teacher candidates in the social studies early childhood program perceive their readiness to apply Vygotsky's ZPD into their teaching after graduation. Some of the previous studies focus on the application of ZPD to the teaching of mathematics (Sophian, 2013), and others also focus their research with the ZPD on language acquisition (Rueda \& Yaden, 2013). This study intends to fill the gap in our knowledge about how some preservice teacher candidates perceive their readiness to apply the ZPD in teaching early childhood social studies after graduation.

\section{Purpose Statement}

Vygotsky's ideas about learning promote cognitive development especially in young learners (Larson \& Keiper, 2011; Tuckman, \& Monetti, 2013). The purpose of this study was to explore the perception of early childhood preservice teacher candidates about their readiness to apply Vygotsky's ZPD in the classroom to promote effective teaching and learning after graduation. Vygotsky's ZPD has become a key concept in teacher pedagogical training because of its promise to promote effective and efficient instructional practices in the classroom.

\section{Conceptual Framework}

According to Marzano and Brown (2009, p. 10), teaching is both an art and science guided by certain principles, rules, and theories (Muth \& Alvermann, 1999; Ornstein \& Sinatra, 2005; Snowman \& McCown, 2015). This argument is supported by others such as Arends (2009, p. 2), and Moore (1999, p. 44). Arends points out that teaching is a science because its practices are based on research and scientific evidence (p. 4). Arends contends further that, teaching is an art because it is based on the teacher's experiences and the wisdom of practice (p. 4). Marzano and Brown (2009, p. 1) argue teaching is "art in the sense that it involves no specific script all effective teachers must follow". Marzano and Brown $(2009$, p. 1) argue further that teaching "is science in the sense that there are strategies that research over time has shown to have a high probability of enhancing student achievement". Effective teaching does not just happen. It is always the result of careful planning, presentation, and assessment. Knowledge construction, according to the extant literature promotes meaningful learning (Berger, \& Luckmann, 1991; Bodrova, 1997; Henson, 2004; Snowman \& McCown, 2015). Knowledge construction or the acquisition of knowledge has for many years been the subject for debate and research. The ancient Egyptians, Greeks, Romans, all 
postulated about the appropriate ways for teaching students to acquire knowledge (Essa, 2011; Powell, 2009).

Cognitive development or knowledge construction is the primary focus of teaching and learning (Powell, 2009; Schickedanz, Schickedanz, Forsyth, \& Forsyth, 2001). Constructivist "view learning as a process not just of acquiring information but of creating new understanding" (Henson, 2004, p. 13.). Although Piaget and other constructivist thinkers such as Locke, Rousseau, Pestalozzi, Johann Herbart, and Dewey have long made significant contributions to the field of knowledge construction, the search for the appropriate learning ecology continues unabated (Goodman, 2000; Henson, 2004). The contributions from these constructivists have always been a subject for debate. According to Vygotsky (1986), "all knowledge, from the most important to the most mundane, is socially constructed" (as cited in Schickedanz, Schickedanz, Forsyth, \& Forsyth, 2001, p. 21). What makes Vygotsky's ZPD to knowledge construction is that it "described the transformation of simple perception, involuntary attention, and simple memory into categorical perception, conceptual thinking, logical memory, and selfregulated attention" (Gredler, 2001, p. 297). The constructivist revolution has brought new conceptions of learning and teaching (Marginson \& Dang, 2017; Susan, 2003). Although constructivism takes many forms, an underlying premise is that learning is an active process in which learners become active sense makers who seek to build coherent and organized knowledge (Henson, 2004; Mayer, 2004).

Learning in the classroom involves the interactions between teachers and students or between students and students. Which of these two is the most productive? According to Vygotsky, children have a specific range or zone within which they can learn efficiently (Maxim, 2010). One zone he describes as the Zone of Actual Development (ZAD) and the other the Zone of Proximal Development (ZPD). The ZAD is the range where students can accomplish tasks on their own without the help of others. When children can solve problems or successfully accomplish tasks based upon their own efforts, we affirm that the task was within their Zone of Actual Development (ZAP). In the ZPD on the other hand, students can only solve problems or accomplish tasks only with the help of significant others or adults who have knowledge about the task in hand. It is in light of this observation that the ideas of Vygotsky's ZPD about knowledge construction have attracted the attention of educators in recent years.

As John-Steiner and Mahn, (1996, p. 191-192) have pointed out:

At a time when psychologists were intent on developing simple explanations of human behavior, Vygotsky developed a rich, multifaceted theory through which he examined a range of subjects including the psychology of art; language and thought; and learning and development, including a focus on the education of students with special needs.

Vygotsky's (1986) thinking indicates that the origin of knowledge construction should not be sought in the mind but in the social interaction co- 
constructed between a more and a less knowledgeable individual (Bodrova, 1997; Lantolf, 2008; Muth \& Alvermann, 1999; Ornstein \& Sinatra, 2005).

Moreover, the construction of knowledge is a sociocultural process impacted by environmental factors such as peers, teachers, and other knowledgeable people in the immediate environment of the individual. affected by the physical and psychological tools and artifacts (Glassman, 2001; Goodman, 2000; Lantolf, 2004).

Vygotsky (1986) developed the theory of ZPD in a critique of the use of Intelligence Quotients (IQ) tests as a form of assessing students. According to Vygotsky, the child with a large ZPD will do much better in school because this measure gives a more helpful clue than mental age does to the dynamics of intellectual progress (Vygotsky, 1986). Vygotsky further argued that children learn with confidence when they are supported by a more knowledgeable person because such positive interactions bring out the specifically human qualities of the mind and lead the child to new developmental levels (Vygotsky, 1986, p. 188, see Figure 1).

Vygotsky's ZPD provides children the avenue to exhibit their learning styles. It is common knowledge that human beings differ in the way they learn. Some learn best by listening (auditory), some learn by looking (visual), some by touching (tactile), and some by performing an action (kinesthetic) (Lerner, 2006, p. 238; Slavin, 2015, p. 93). When providing support for a child within the ZPD, teachers are able to identify appropriate learning styles to apply effective learning and teaching strategies to help the child learn how to learn to become learners.

According to Seefeldt, Castle, and Falconer (2014, p. 11) Vygotsky's knowledge construction approach includes the following:

- A person's social and psychological worlds are constructed.

- Child-adults interaction is important for cognitive development.

- The capacity to use language to regulate thought and action is distinctly human and the source of the conscious mental life.

- Social experience is extremely important for cognitive growth.

- Education leads to development.

- Teaching must be geared to the zone of proximal development; that is, it must match what it is to be taught to what the child already knows and will be able to accomplish with adult help until it can be accomplished independently.

The integration of behavior and consciousness or the unification of mind and social interaction is a major characteristic of Vygotsky's developmental theories because it defines precisely what constitutes human development and knowledge construction (Bodrova, 1997; Schickedanz, Schickedanz, Forsyth, \& Forsyth, 2001; Shabani, 2016).

Vygotsky (1986) stressed that language development is the key to knowledge construction. As observed by Schickedanz, Schickedanz, Forsyth, \& Forsyth (2001, p. 22): 
The cultural-historical aspect of Vygotsky's theory states that these important linguistics structures, thoughts, and ways of thinking are not developed independently by each child but are instead the product of a long line of individual children's interactions with more advanced members of their culture.

Figure 1. Vygotsky's Zone of Proximal Development

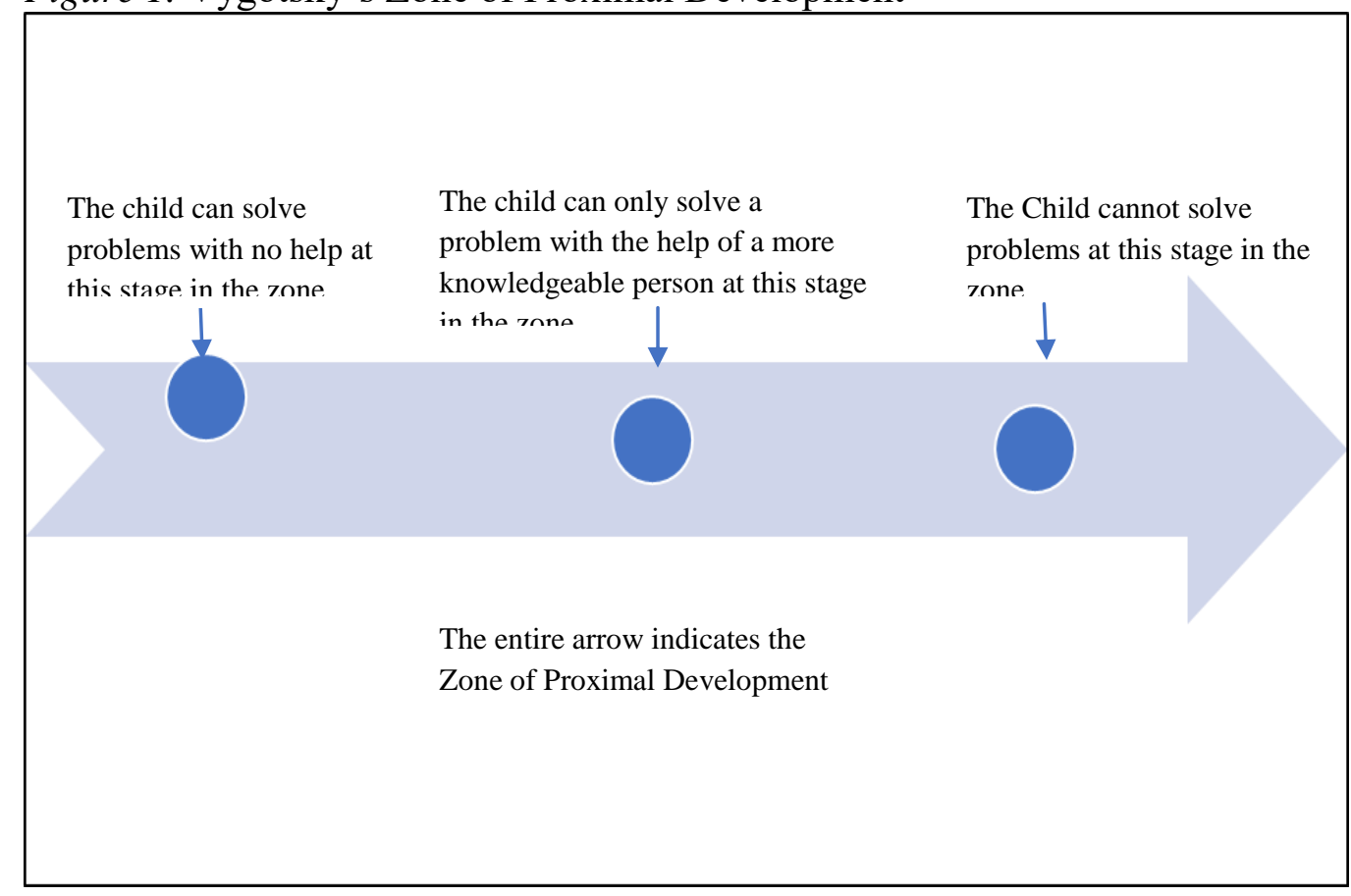

\section{Significance of the Study}

This study focused on one major theory, the ZPD as developed by Vygotsky (1986), the Russian educator and psychologist, to shed light on teacher preparation by an EPP. Vygotsky's ideas about knowledge construction have become part of teacher preparation because of its promise to provide learners the foundation blocks for critical thinking to provide them the means to take ownership of their learning (Henson, 2004; Mayer 2004; Tuckman \& Monetti, 2013).

The ideas of Vygotsky (1986) were suppressed by the Soviet government because his methods were not deemed rigorous or "radical" enough to spark revolutionary tendencies in the learner, especially young children (Schickedanz, Schickedanz, Forsyth, \& Forsyth, 2001; Susan, 2003; Marginson \& Dang, 2017). However, Vygotsky's ideas about cognitive development have become a new approach to the principles of teaching and learning because of its propensity to promote intellectual development in a learner (Cox, 2008; Maxim, 2010). As noted by Larson and Keiper (2011, p. 92):

Current thinking about the ideas tied to Vygotsky's ZPD theory has led to such terms as scaffolding, constructivism, and hands-on learning. These imply that learning occurs when some additional source provides a support 
network to promote learning (e.g. in the same way that a scaffold provides support for a building.

The findings from this study will also add to our growing body of knowledge about how to create developmentally appropriate instructional ecology for the education of children, especially those in the early childhood classes (Snider \& Fu, 1990). The difficulty level of material is an extremely important consideration when teaching, especially young children (Lerner, 2006).

Creating the developmentally appropriate instructional ecology is important in the education of children, especially young ones. When Helen Keller's teacher, Annie Sullivan, created the appropriate instructional ecology, she was able to teach Helen Keller, a blind and dumb student to read and write (Davidson, 1965). Research indicates that providing children with minimal support during instruction is not enough to help them positively engage in the lesson. Several reviews of empirical studies have established a solid research-based case against the use of instruction with minimal guidance (Kirschner, Sweller, \& Clark, 2006). Mayer (2004) reviewed over 50 articles written about instructional strategies and concluded from the study that knowledge construction such as recommended by Vygotsky's ZPD, especially for young children, is the preferred choice by many educators.

As constructivism has become the dominant view of how students learn, it is very important that EPPs find empirical-based research to refine the curriculum for teacher preparation (Mayer, 2004). The proposed study builds on literature written about learning theories and the quest for developmentally appropriate practice in the early childhood classroom, approximately from infancy to the third grade or age 8 (Driscoll, \& Nagel, 2008; Essa, 2011; Morrison, 2012). Moreover, empirical research such as this one exploring the perception of preservice teacher candidates about the process for implementing the ZPD is likely to support and promote the professional development of early childhood teachers (Driscoll \& Nagel, 2008; Essa, 2011; Morrison, 2012; Snider \& Fu, 1990).

\section{Research Questions}

As already pointed out, the main purpose of this study is to explore the perception of early childhood teacher candidates about their readiness to apply Vygotsky's ZPD in the early childhood social studies classroom after graduation. Exploring and examining these perceptions is likely to help educators lay a solid foundation for the application of Vygotsky's ideas in teaching social studies to young children (Seefeldt, Castle, \& Falconer, 2014).

The following research questions were formulated based upon the extant literature on developmentally appropriate instructional approaches for early childhood education:

1. How do teacher candidates perceive the integration of Vygotsky's Zone of Proximal Development in the curriculum? 
2. What problems do the pre-service teachers anticipate implementing the Zone of Proximal Development in their teaching after graduation?

3. What skills has their teacher education program equipped them to implement the Zone of Proximal Development in their teaching after graduation?

4. How do these pre-service teachers plan to learn more about the Zone of Proximal Development?

\section{Methods}

\section{Design and Procedure}

This was a qualitative case study designed to explore the perception of preservice teachers about the integration of Vygotsky's ZPD into teaching social studies in the early childhood classroom. The qualitative approach was preferred to other research methods because qualitative approach to the study of social phenomena provides the researcher the opportunity to suggest grounded propositions, provide explanations to extend the understanding of phenomena, or promote opportunities for informed social action (Creswell, 2014; McMillan \& Schumacher, 2006; Ravitch \& Carl, 2016).

The primary data for the study were collected through interviews and document analysis, such as information in textbooks, the Internet, and journal articles on curriculum development such as early childhood education. Five students in a Southern University in the United States were conveniently selected to participate in the study. Convenience sampling method was used because the opinion of these five preservice social studies was considered more valuable than those that would be obtained in a random sample of all the students in the teacher education program (White \& McBurney, 2013).

The College of Education has a small teacher education department with only about 30 teacher candidates. These teacher candidates were specializing in different areas of study. Five specialized in Integrated Mathematics, 3 specialized in Integrated Science Education, 11 specialized in Physical Education, 6 specialized in Music and 5 others specialized in Early Childhood Education. In order to increase the sample size for the study, all the five teacher candidates specializing in the Early Childhood Education program were conveniently selected to participate in the study. All five teacher candidates had completed a course in social studies pedagogy. Of the five students selected to participate in the study, three were male students and two were female students. One of the three male students was a Caucasian, the second was an Asian student and the third an African American student. Both female students were Caucasian. All the participants were junior students and had completed several educational theories such as behaviorism, social cognitive learning, information processing theories, theories of human development, multiple intelligence theory, theories of social and emotional development, and Vygotsky's Zone of Proximal Development (Driscoll \& Nagel, 2008; Essa, 2011; Woolfolk, 2007). 
Table 1. Demographics of the Participants

\begin{tabular}{|l|c|c|c|c|c|}
\hline $\begin{array}{l}\text { Name } \\
\text { (Synonym) }\end{array}$ & Race & Age & Gender & $\begin{array}{c}\text { Student } \\
\text { Status }\end{array}$ & $\begin{array}{c}\text { Early Childhood } \\
\text { Education (ECE) } \\
\text { Methods/Pedagogy Social } \\
\text { Studies Course Completed }\end{array}$ \\
\hline Maria & Caucasian & 28 & Female & Junior & Yes \\
\hline Akua & Caucasian & 25 & Female & Junior & Yes \\
\hline Abu & $\begin{array}{c}\text { African } \\
\text { American }\end{array}$ & 28 & Male & Junior & Yes \\
\hline Krishna & Asian & 30 & Male & Junior & Yes \\
\hline Mark & Caucasian & 25 & Male & Junior & Yes \\
\hline
\end{tabular}

All these preservice teacher candidates were conveniently selected to participate in the study because as part of their teacher education program, they were expected to integrate educational theories, models, or concepts into their teaching. During the field experience component of their teacher preparation, each student used the ZPD method to teach young children social studies lessons. In effect, they were expected by their university supervisors to be innovative in the classroom and not to teach the way they were taught when they were toddlers or young children.

\section{Interview}

Open-ended interviews were used to collect the data for this qualitative study. Each student was interviewed for about 30 minutes with the same questions in the same order but different follow up questions in order to probe for consistent responses (Best \& Khan, 2006). In any given interview situation, some participants tend to include probes in their responses. Such probes tend to prolong the time for the interview and stretch the interview beyond the original scope for the study. These probes constitute what Webb, Campbell, Schwartz, and Sechrest, (1966) call the dross rate. Again, as observed by McMillan and Schumacher (2006), "Qualitative in-depth interviews are noted more for their probes and pauses" (p. 353) and so the participants were given enough time to elaborate on their responses (Best \& Khan, 2006; Rubin \& Rubin, 2012).

However, to cut down on dross rate, the participants who tended to dwell further on issues or engaged in continuous, or elaborate probes were quickly but politely reminded to focus on ideas that were germane to the study. Through such interview strategies, the participants were encouraged to focus their responses on concepts or ideas that had the promise of yielding the appropriate data for the study (Johnson, 1975; Ravitch \& Carl, 2016; Webb, Campbell, Schwartz, \& Sechrest, 1966).

One of the interview questions was this: "What problems do you anticipate implementing the ZPD in your teaching after graduation?" Another interview question was this: "How do you plan to overcome the difficulties that you perceive in implementing the ZPD in the classroom after your graduation?" 


\section{Archival Records}

Other sources for the data collection included internet sources, books, journal articles, and magazines. These sources were used to provide further evidence to support the information from the participants (Salkind, 2012). Content analysis or extraction of data from archival sources provides unobtrusive measures when studying phenomenon (Webb, Campbell, Schwartz, \& Sechrest, 1966). These unobtrusive measures provide information that sheds further light on the responses to the research questions without further interference from the respondents, although this might constitute using someone else's filter for the study (Ravitch \& Carl, 2016; Webb, Campbell, Schwartz, \& Sechrest, 1966).

\section{Data Analysis}

Before any meaningful data analysis could be performed, I had to reduce the lengthy information from my participants into manageable chunks of information. Some of the major codes that emerged from the interviews included "lack of resources, time, classroom procedures, classroom arrangements, learning rates, learning styles, class size, attention span, critical thinking, knowledge construction, and ownership of learning." Open, axial, and selective coding were used to categorize the data into themes for the study. Similar ideas were placed into broad categories and later into separate themes as recommended by Ravitch and Car (2016), Ary, Jacobs, Sorensen, and Walker (2014), Creswell (2014). In some cases, multiple codes were assigned to a particular category in order to close all the gaps in the data analysis.

Ravitch and Car (2016, p. 251) recommendations were used as the foundation for creating the codes. Therefore, the approach for creating the codes included checking or looking for:

- Repetition in and across various data items

- Strong or emotive language

- Agreement between individuals

- Concepts that are not discussed or commented on

- Disagreement between individuals

- Mistakes and how/if they are solved

Finally, code definitions and data displays were used to develop themes to draw conclusions for the final report (see Table 2). 
Table 2. Data Display for Analysis

\begin{tabular}{|c|c|c|}
\hline Code Sets & Categories & Research Questions \\
\hline $\begin{array}{l}\text { Classroom Procedures, } \\
\text { Motivation, Teaching Tools, } \\
\text { Student Behavior } \\
\text { Seating Arrangements }\end{array}$ & $\begin{array}{l}\text { Classroom } \\
\text { Management }\end{array}$ & $\begin{array}{l}\text { How do you plan to overcome the } \\
\text { difficulties that you perceive in } \\
\text { implementing the ZPD in the } \\
\text { classroom after your graduation? }\end{array}$ \\
\hline $\begin{array}{l}\text { Learning Styles, Learning Rate, } \\
\text { Grouping, Asking Questions, } \\
\text { Modeling, Guided Practice, } \\
\text { Feedback, Concepts } \\
\text { Scaffolding }\end{array}$ & Pedagogy & $\begin{array}{l}\text { How do you plan to overcome the } \\
\text { difficulties that you perceive in } \\
\text { implementing the ZPD in the } \\
\text { classroom after your graduation? } \\
\text { How do you perceive the } \\
\text { integration of the ZPD in the } \\
\text { curriculum? } \\
\text { How do you plan to learn more } \\
\text { about the use of ZPD in the } \\
\text { classroom? }\end{array}$ \\
\hline $\begin{array}{l}\text { Knowledge Construction, } \\
\text { Grouping, Critical Thinking, } \\
\text { Student Achievement } \\
\text { Professional Development } \\
\text { Technology } \\
\text { Cooperative Learning }\end{array}$ & $\begin{array}{l}\text { Student } \\
\text { Learning }\end{array}$ & $\begin{array}{l}\text { How do you plan to learn more } \\
\text { about the use of ZPD in the } \\
\text { classroom? } \\
\text { What teaching skills did your } \\
\text { pedagogy course provide you } \\
\text { with teaching young children? } \\
\text { How do you understand the ZPD } \\
\text { as developed by Vygotsky? }\end{array}$ \\
\hline $\begin{array}{l}\text { Class Size, Technology, } \\
\text { Teacher Assistant } \\
\text { Student Behavior } \\
\text { Time, Cognitive Development } \\
\text { Scaffolding }\end{array}$ & Problems & $\begin{array}{l}\text { What problems do you anticipate } \\
\text { implementing the ZPD in your } \\
\text { teaching after graduation? }\end{array}$ \\
\hline $\begin{array}{l}\text { Learning Styles, Critical } \\
\text { Thinking, Grouping, Hands-on- } \\
\text { Learning, Scaffolding } \\
\text { Constructivism } \\
\text { Technology, YouTube }\end{array}$ & $\begin{array}{l}\text { Knowledge } \\
\text { Construction }\end{array}$ & $\begin{array}{l}\text { How do you understand the ZPD } \\
\text { as developed by Vygotsky? } \\
\text { How do you plan to use the ZPD } \\
\text { when teaching social studies to } \\
\text { young children? } \\
\text { How do you plan to learn more } \\
\text { about the use of ZPD in the } \\
\text { classroom? }\end{array}$ \\
\hline
\end{tabular}

\section{Results}

The results of this study will be discussed within the conceptual framework and the guiding research questions. One major problem with qualitative study is the task of making sense of the volume of data that emerge from interviewing 
participants. Sometimes the information is so large and voluminous that the researcher must sift through notes upon notes, data upon data in order to craft a report that meets the expected outcome for the study. This study did not avoid this qualitative tradition. The research questions guided the study and eventually became the major coding categories. In the following section, the most interesting themes that emerged from the interviews will be presented.

\section{The Integration of Vygotsky's Zone of Proximal Development in the Curriculum}

Vygotsky's Zone of Proximal Development deals essentially providing instructional support and assistance to learners from multiple perspectives. It implies working and supporting the thinking, reasoning and logical thinking of students to arrive at the desired outcomes of the instructional process. Each preservice teacher candidate had no problem providing a positive response to this question: "How do teacher candidates perceive the integration of Vygotsky's Zone of Proximal Development in the curriculum?" Akua, a Caucasian female preservice teacher candidate, had this to say, "The integration of Vygotsky's ZPD in the classroom is something we do all the time. In the methods courses, we are always instructed to be supportive of the effort's kids make to make sense of what they learn. Guided practice, grouping, or scaffolding are all the teaching strategies that we are asked to use to help kids master content. Kids at this stage need the support of teachers to make sense of what they learn in the classroom."

Abu, an African American male student, did not find it hard adding his voice to this question. From Abu's point of view, the integration of the ZPD in the curriculum is appropriate for all children especially kids who are beginning to learn new things and concepts to build a scholarship of reading, writing, and computations. "At the early grades, one approach I find effective is using convergent questions to assess student learning. When I use this approach, I get the opportunity to assess what most of the students have learned about key concepts being taught" Abu added.

"Every curriculum that tends to promote effective instruction in the early grades uses the ZPD to help kids master essential concepts. Kids in the early stages need to be scaffolded to master the art of reading, writing, computing, and communicating." These were the words that Krishna, an Asian student who appeared to be the oldest student in the class added to the conversation.

\section{Problems Pre-Service Teachers Anticipate Implementing the ZPD in their Classroom after Graduation}

The students provided dismal responses to the research question about the problems they anticipated implementing the ZPD in their classroom after graduation. The research question was this: What problems do you anticipate implementing the Zone of Proximal Development in your teaching after graduation? All five preservice teachers provided similar responses. These were listed as follows: 
- Class Size,

- Technology,

- Teacher Assistant,

- Student Behavior,

- Time.

All the pre-service teacher candidates opined that a large class size of say, 15, 20, 25 would impede the smooth implementation of the ZPD in the classroom. Maria added even a class size of 10 with a limited amount of time, supplies, and different learning rates and styles would make the implementation difficult. "I remember in the school where I did my field experience, some of the kids had behavioral problems and therefore I found it very difficult implementing my lesson. I was lucky the cooperating was close by to offer me the help I needed to keep the class focused on what I was teaching them" she added.

Mark, a Caucasian male student also echoed similar sentiments about the problems he anticipated facing implementing the ZPD in his classroom after graduating. "Some of the kids in my second-grade class during my field experience were perhaps not used to taking turns using materials. Instructional materials were not enough for all the students to be doing the same thing at the same time. There was, therefore, the need for some of the students to take turns using such materials in learning. However, some of the students violated the rules of taking turns and often snatched specific crayon colors from their mates."

Maria was quick to observe that during her field experience, the cooperating teacher often gave her a maximum of five students to teach. "When my supervision teacher came to observe me, I had no problem managing my class. I was able to provide the students-one-on- support to master the material I was teaching them. The supervisor was impressed with my work." Maria added, "I could not have achieved this feat if the class size was more than 10 "

\section{Teaching Skills the Pre-Service Teachers Have Been Taught to use to Implement the ZPD in the Early Childhood Classroom}

Vygotsky's Zone of Proximal Development (ZPD) is about providing scaffolding for children to learn. Scaffolding occurs when adults or more experienced persons model what must be learned to the child and then support the child to do the same. The application of scaffolding differs from grade level to grade level. This implies that teachers or adults guiding children to learn new tasks in the classroom must design the learning task to meet the cognitive development of the children. The following teaching strategies are what emerged from the interview with the preservice teachers as the appropriate strategies for implementing the ZPD in the early childhood social studies classroom:

- Modeling,

- Guided practice or guided discovery,

- Application practice,

- Grouping,

- Tutoring. 
With modeling, Abu said that teachers take the lead in modeling or practically demonstrating the correct way for mastering a skill or learning the meaning of concepts, historical events, writing, reading, or speaking. "Teachers can model the correct way of doing things to kids in almost all situations. The best way to model the appropriate behavior is to use a step by step approach while modeling the correct way or procedure for mastering the learning task or event to students". Maria, Krishna, and Akua all added that after the modeling comes the guided practice or guided discovery phase. During the guided practice phase, teachers provide immediate responses and specific feedback to the kids. Krishna added "During the guided practice phase, the teachers should pay close attention to what the kid does. The main role of the teacher should be a guide by the side of the student."

Maria added that during the guided practice phase, "it is ok for teachers sometimes to physically intervene or implement direct instruction approach and then leave the student to master the task on his/her own."

In order to find out what the kids have learned, it is often desirable to assign students tasks that will provide them the opportunity to apply what they have learned with the help of the teacher in a new situation. This is the implication of their responses.

On grouping, the pre-service teachers observed that grouping kids without the presence of an adult often leads to chaotic situations in the classroom. Akua said "Kids are not matured enough to know the benefit of working under a leader who appears to be of the same age or at cognitive level with them. Therefore, for grouping as a teaching strategy to work, the kids need to work with an adult such as the teaching assistant as the group leader." Abu added that he will not use grouping as an instructional strategy in the early childhood classroom to implement ZPD because it is likely to obscure or mar the instructional ecology. "I would rather use whole-class instructional approach to implement the ZPD in my social studies early childhood classroom through the process of modeling, guided practice and application practice."

Although tutoring is not usually the preferred method of implementing the ZPD in the social studies early childhood classroom, the preservice teachers did not rule out this option when necessary. All five preservice teachers agreed that tutoring is the most effective way to help struggling students to master content, especially for those students whose learning rate is below the grade level. The extant literature supports this point of view. This is because tutoring has the potential to provide slower learners the means to organize their thoughts and reasoning abilities to arrive at logical conclusions (Ornstein, \& Sinatra, 2005).

\section{Planning to Learn More about the Zone of Proximal Development}

The main question asked was this: "How do you plan to learn more about the Zone of Proximal Development?"

Professional development was the first means the pre-service teachers identified. Through professional development, the students hoped to learn more about Vygotsky's ZPD. The students were not specific about the type of 
professional development that they thought would help them. When I probed further $\mathrm{Abu}$ and Maria identified workshops on pedagogy as the type of professional development that would help them keep abreast with their pedagogical practices including mastering the ZPD. Maria, Krishna, and Akua mentioned apart from professional development on pedagogy conference, they planned to search YouTube or Teacher Tube for videos on student engagement in the classroom.

Another route some of them mentioned was enrolling in a graduate program in teacher education. "Graduate program in curriculum and instruction, with a concentration in early childhood education, will provide me the opportunity to learn more about ZPD" was the prolonged response from Maria, when pressed to be more specific about her plans to expand her knowledge about Vygotsky's ZPD.

Mark also indicated that he will read magazines on teaching and learning or books on teaching and learning to broaden his outlook on the implementation of the ZPD in the classroom. He added that "the Internet is another source where teachers are capable of learning new tools and strategies for mastering the art and science of teaching." Unfortunately, none of the five participants could mention any magazine on pedagogy that would be of further help to them.

\section{Discussion}

The purpose of this study was to explore the perception of early childhood teacher candidates about their readiness to apply Vygotsky's ZPD in the classroom to promote effective teaching and student engagement after graduation. The research questions focused on the perceptions of the pre-service teachers about their readiness to implement Vygotsky's ZPD in the early childhood classroom when teaching social studies.

The responses from the students to most of the major interview questions about the implementation and application of the ZPD in early childhood classrooms gave a clear indication of their understanding of the process. All of them agreed the application of the ZPD in the early childhood classroom promotes social interaction and effective learning. This observation is supported by findings from others such as Essays, UK (2018) when discussing the application of Vygotsky's theory during the early years of a child's education.

Nevertheless, all the students anticipated problems implementing the ZPD in their social studies classroom. Among the numerous problems they cited included large class size, time, and student behavior. Although the problems they enumerated are clear, in some cases, they should not feel uncomfortable with such issues as group work. It is clear in the early childhood classroom, children by nature do not cooperate very well, teachers should use this background information or developmental stage characteristic to help students learn to share and cooperate to do things in the classroom. As Bekiryazici, (2015) put it "To make the learning environment better, teachers should be careful about grouping the students according to their abilities, not dividing the class into higher-lower levels, but rather in a mixed way where every student can learn from each other." (p. 916). 
The problems identified by the preservice teachers are like what even many experienced teachers face in most classrooms (Gredler, 2001; Ornstein, \& Sinatra, 2005; Marzano, 2007). The important thing the pre-service teachers or other beginning teachers should know is that the ZPD has logical steps that must be followed if they want to apply the model effectively in the classroom to engage students. Below is the step-by-step process by which a teacher may use to apply the ZPD in the classroom as outlined by Winkler (2019):

- First, a teacher should identify what a student already knows. By identifying this prior knowledge, the teacher can build on that skill when introducing new concepts.

- Next, the teacher can build on this knowledge through scaffolding; the scaffold will help students move from what they already know to what they should know by the end of class. When planning lessons, teachers should keep in mind the scaffolding process by integrating guided practice in their lesson plans.

- Last, teachers can help students connect their new learning to their prior knowledge. For example, if a math teacher has just taught children how to master dividing decimals, the teacher might then relate this concept back to multiplying decimals.

All in all, through the application of the concept of the ZPD, the teacher first identifies what children already know, then teaches them something new to add to it, and then helps the children relate this back to their prior knowledge so that they can now understand the new concept without assistance (Gredler, 2012; Muth, \& Alvermann, 1999). Put succinctly, Farris (2015) argues that children can do things they cannot do on their own but when provided the appropriate assistance from a more knowledgeable person, "they will eventually be able to do successfully all by themselves later." (p. 16).

As clearly pointed out by Slavin (2015) and Woolfolk (2007) the application of the ZPD model in the classroom is not a guarantee that the students will become efficient learners. What the model teaches is that children need guidance from adults or significant others when learning. The model does not support Plato's idea of human beings born with ideas. Like the constructivist view on learning, the model supports John Locke's view of the human brain as being tabular rasa at birth, a blank slate that contains no ideas (Ornstein \& Levine, 2006). It is, therefore, very important that teachers bear this point in mind when applying the ZPD in the lower grades (Gredler, 2012; Muth \& Alvermann, 1999).

As studies continue to demonstrate the implication of the ZPD in the early childhood classroom, (Ehrich, 2006; Verenikina, 2003, 2010) teachers must realize that in order for the ZPD to work effectively, they must "pay careful attention to the levels at which they instruct students as well as the levels of the tasks they ask students to do on their own" (Muth \& Alvermann, 1999, p. 34). Vygotsk's ZPD from the point of view of the pre-service teacher candidates is a relevant model for providing scaffolding to support the efforts of students, 
especially the younger ones, in the classroom to make sense of what they learn (Gredler, 2012).

Above all, this study has made it clear that the days when early childhood teachers did not receive training like the ancient days or during the colonial times in America, today, teaching and learning have assumed new perspectives. Individuals who want to be teachers must be prepared to receive training in both pedagogy and content areas and apply the principles of effective teaching and learning in the classroom in the proper instructional ecology framework (Arends, 2009; Cochran-Smith \& Villegas, 2015; Essa, 2011).

\section{Implications for Future Research}

While this research adds important knowledge to the literature on the preparation of early childhood social teachers, the present findings have implications that could be addressed by further research. One concerns research into the readiness of early childhood preservice social studies teachers to apply integrated social studies content in the classroom. Research into the readiness of early childhood social studies preservice to apply integrated social studies content in the curriculum is important because the extant literature suggests there is a strong correlation between knowledge of content and the application of pedagogical practices (Farris, 2015; Fritzer \& Brewer, 2010; Seefeldt, Castle, \& Falconer, 2014).

Another area worthy of research is the professional development of early childhood social studies preservice teachers. The inability of the participants to identify any professional journal for the social studies appears to be a deficit in their professional preparation, although they were able to identify different tools and resources, they might use to sharpen their professional practice after graduation.

Finally, the present findings indicate classroom management might be a problem for some of the preservice social studies teachers after their graduation. It is therefore important for other scholars to take a critical look at how social studies preservice teachers are prepared to promote effective classroom management when delivering instruction within an effective instructional ecology (Farris, 2015; Fritzer \& Brewer, 2010; Seefeldt, Castle, \& Falconer, 2014).

\section{Limitation}

The sample size for this study was only five preservice early childhood social studies students in the early childhood program in the institution. As already pointed out, these five preservice teachers were part of a larger graduating class of about 30 preservice teachers. The students specialized in different academic areas. Out of the 30 preservice teachers, only five specialized in early childhood education. Teaching social studies methods is one of the courses these students had to complete for the early childhood specialization program. Although the qualitative approach to social inquiry makes this small sample size appropriate for the study (Creswell, 2014; White \& McBurney, 2013), the finding from this study 
may not be generalized to other populations. Additionally, the students were all conveniently selected from one educator preparation provider (EPP) program in the southern region of the United States. It is therefore not recommended that readers apply the findings from this study to other regions with similar EPP programs (McMillan, 2012).

\section{Delimitation}

This study was limited to teacher candidates in only one educator preparation program (EPP) in the southern region of the United States. Though both men and women were included in the study, separate data analyses of the responses to the research questions were based on sex and gender. Additional research with a different research approach such as mixed-methods, region, or sample size, is needed for such analyses (Ary, Jacobs, Sorensen, \& Walker, 2014; Creswell, 2014).

\section{Conclusion}

The discussion about instructional ecology and the application of Vygotsky's ZPD in the classroom were presented within the cognitive construction framework and the research questions. Four conclusions may be drawn from this study. The first is that as educators prepare candidates to enter the teaching profession, they look for theories and pedagogical strategies that are likely to equip the preservice teachers the skills that will help them provide support for student learning within the proper instructional ecology.

The second is that Vygotsky's ZPD has gained universal acceptance as a method of instruction for all grade levels, especially at the lower grades where children need close attention and support from teachers and others who are able to provide clues, structure, or steps for accomplishing specific tasks. Because of this, all major EEPs include a course on Vygotsky's ZPD and other pedagogical approaches in their curriculum for teacher education.

Third, the problems the pre-service teachers perceived may be illusive. The main goal of Vygotsky's ZPD is to promote efficient learning in the classroom. His goal was not to introduce complex and inefficient methods for instructing learners. Perhaps, if Vygotsky had lived long enough to elaborate on his ideas and pedagogical research, he would have provided us answers to these perceived problems. Most of the applications of ZPD in different classrooms as described today in the literature have been created by scholars from their own point of view. As Woolfolk (2007) has put it, “...we don't even know if Vygotsky would agree with them."

Finally, this study extends our knowledge about the application of Vygotsky's ZPD in the early childhood social studies classroom. As Woolfolk (2007, p. 49) has pointed out, "Sometimes the best teacher is another student who has just figured out how to solve the problem, because this student is probably operating in the learner's zone of proximal development." Perhaps, this is a pioneer study in the 
area of instructional design and application. It is because of this that the findings from this study may not be extended to other situations operating within different instructional ecology.

\section{References}

Arends, R.I. (2009). Learning to teach. Boston, MA: McGraw-Hill Higher Education.

Ary, D., Jacobs, L.C., Sorensen, C.K., \& Walker, D. A. (2014). Introduction to research in education. Belmont, CA: Wadsworth, Cengage Learning.

Bekiryazici, M. (2015). Teaching Mixed-Level Classes with A Vygotskian Perspective. Procedia-Social and Behavioral Sciences, 186, 913 - 917.

Berger, P.L., \& Luckmann, T. (1991). The social construction of reality: A treatise in the sociology of knowledge. England, Penguin Books.

Best, J.W., \& Kahn, J.V. (2006). Research in education. Boston, MA: Pearson.

Bodrova, E. (1997) Key concepts of Vygotsky's theory of learning and development, Journal of Early Childhood Teacher Education, 18:(2), 16-22. doi:10.1080/109010 2970180205

Cochran-Smith, M., \& Villegas, A.M. (2015). Framing teacher preparation research: An overview of the field, part 1, Journal of Teacher Education, 66(1), 7-20.

Cox, C. (2008). Teaching language arts: A student-centered classroom. Boston, MA: Pearson.

Creswell, J.W. (2014). Research design: Qualitative, quantitative, and mixed methods approaches. Los Angeles, CA: Sage.

Davidson, M. (1965). Hellen Keller's teacher. New York, NY: Scholastic Inc.

Driscoll, A., \& Nagel, N.G. (2008). Early childhood education, birth-8: The world of children, families, and educators. Boston, MA: Pearson Education.

Ehrich, J. F. (2006). Vygotskyan inner speech and the reading process. Australian Journal of Educational and Developmental Psychology, 6, 12-25.

Essa, E.L. (2011). Introduction to early childhood education. Belmont, CA: Wadsworth, Cengage Learning.

Essays, UK. (November 2018). Application of Vygotsky's learning theories in early years. Retrieved from https://bit.ly/325YemB.

Farris, P.J. (2015). Elementary and middle social studies: An interdisciplinary, multicultural approach. Long Grove, IL: Waveland Press.

Fritzer, P.J., \& Brewer, E.A. (2010). Social studies content for elementary and middle school teachers. Boston, MA: Allyn \& Bacon.

Glassman, M. (2001). Dewey and Vygotsky: Society, experience and inquiry. Educational Researcher, 30, 3-14. doi:10.3102/0013189X030004003

Goodman, J.F. (2000). Moral education in early childhood: The limits of constructivism, Early Education and Development, 11(1), 37-54.

Gredler, M.E. (2001). Learning and instruction: Theory into practice. Columbus, OH: Merrill Prentice Hall.

Gredler, M.E. (2012). Understanding Vygotsky for the classroom: Is it too late? Educational Psychology Review, 24,113-131.

Henson, K.T. (2004). Constructivist teaching strategies for diverse middle-level classrooms. Boston, MA: Pearson.

John-Steiner, V, \& Mahn, H. (1996). Sociocultural Approaches to Learning and Development: A Vygotskian Framework. Educational Psychologist, 31(3/4), 191206. 
Johnson, J.M. (1975). Doing field research. New York: NY: The Free Press.

Kaplan, L.S., \& Owings, W.A. (2011). American education: Building a common foundation. Belmont, CA: Wadsworth, Cengage Learning.

Kirschner, P.A., John Sweller, J., \& Clark, R.E. (2006). Why Minimal Guidance During Instruction Does Not Work: An Analysis of the Failure of Constructivist, Discovery, Problem-Based, Experiential, and Inquiry-Based Teaching, Educational Psychologist, 41(2), 75-86.

Lantolf, J. P. (2004). Overview of sociocultural theory. In O. S. John, K. van Esch, \& E. Schalkwijk (eds.), New insights in second language learning and teaching (pp. 1334). Frankfurt: Peter Lang Verlag.

Lantolf, J. P. (2008). Sociocultural theory and the teaching of second languages. London: Equinox Publishing.

Larson, B.E., \& Keiper, T.A. (2011). Instructional strategies for middle and secondary social studies: Methods, assessment, and classroom management. New York, NY: Routledge

Lerner, J. (with F. Kline) (2006). Learning disabilities and related disorders: Characteristics and teaching strategies. Boston, MA: Houghton Mifflin Company.

Marzano, R.J. (2007). The art and science of teaching. Alexandria, VA: Association for Supervision and Curriculum Development (ASCD).

Marzano, R. J., \& Brown, J.L. (2009). A handbook for the art and science of teaching. Alexandria, VA: Association for Supervision and Curriculum Development (ASCD).

Maxim, G.W. (2010). Dynamic social studies for constructivist classrooms: Inspiring tomorrow's social scientists. Boston, MA: Allyn and Bacon.

Marginson, S., \& Dang, T.K.A. (2017). Vygotsky's sociocultural theory in the context of globalization, Asia Pacific Journal of Education, 37(1), 116-129, doi: 10.1080/021 88791.2016 .1216827

Mayer, R. E. (2003). Learning and instruction. Upper Saddle River, NJ: Prentice-Hall.

Mayer, R. (2004). Should there be a three-strikes rule against pure discovery learning? The case for guided methods of instruction. American Psychologist, 59(1), 14-19.

McMillan, J.H. (2012). Educational research: Fundamentals for the consumer. Columbus, $\mathrm{OH}$ : Pearson.

McMillan, J.H., \& Schumacher, S. (2006). Research in education: Evidence-based inquiry. Boston, MA: Pearson.

Moore, K.D. (1999). Middle and secondary instructional methods. Boston, MA: McGrawHill

Morrison, G.S. (2012). Early childhood education today. Boston, MA: Pearson.

Muth, K.D., \& Alvermann, D.E. (1999). Teaching and learning in the middle grades. Boston: MA: Allyn and Bacon.

Ornstein, A.C., \& Sinatra, R.C. (2005). Instructional methods: A literacy perspective. Boston, MA: Pearson.

Ornstein, A.C., \& Levine, D.U. (2006). Foundations of education. Boston, MA: Houghton Mifflin Company.

Powell, S.D. (2009). An introduction to education: Choosing your teaching path. Columbus, OH Pearson.

Ravitch, S.M., \& Carl, N.M. (2016). Qualitative research: Bringing the conceptual, theoretical, and methodological. Thousand Oaks, CA: Sage.

Rubin, H.J., \& Rubin, I.S. (2012). Qualitative interviewing: The art of hearing data. Los Angeles, CA: Sage.

Rueda, R., \& Yaden, D.B. (2013). The education of young dual-language learners: An overview. In O.N. Saracho (with Spodek, B.) (Eds.), Handbook of research on the education of young children (pp. 157-168). New York, NY, and London; Routledge. 
Sanchez, R.M. (2010). The six remaining facts: Social studies content knowledge and elementary preservice teachers. Action in Teacher Education, 32(3), 66-78.

Schickedanz, J.A., Schickedanz, D.I., Forsyth, P.D., \& Forsyth, G.A. (2001). Understanding children and adolescents. Boston, MA: Allyn and Bacon.

Seefeldt, C, Castle, S., \& Falconer, R. (2014). Social studies for the preschool/primary child. Columbus, $\mathrm{OH}$ : Pearson.

Shabani, K. (2016). Applications of Vygotsky's sociocultural approach for teachers' professional development. Cogent Education, 3(1). 1-10.

Slavin, R.E. (2015). Eduational psychology: Theory and practice. Columbus, $\mathrm{OH}$ : Pearson.

Snider, M.H., \& Fu, V.R. (1990). The effects of specialized education and job experience on early childhood teachers' knowledge and developmentally appropriate practice, Early Childhood Quarterly, 5, 69-78.

Snowman, J., \& McCown, R. (2015). Psychology applied to teaching. Stamford, CT: Cengage Learning.

Sophian, C. (2013). Mathematics for early childhood education. In O.N. Saracho (with Spodek, B.) (eds.), Handbook of Research on the Education of Young Children (pp. 169-196). New York, NY, and London: Routledge.

Susan, P. (2003). A biographic comparison tracing the origin of their ideas of Jean Piaget and Lev Vygotsky. Retrieved from ERIC database. (ED478987)

Tuckman, B.W., \& Monetti, D. M. (2013). Educational psychology with virtual psychology labs. Belmont, CA: Wadsworth Cengage Learning.

Verenikina, I (2003). Understanding scaffolding and the ZPD in educational research, Proceedings of the International Education Research Conference (AARE - NZARE), 30 November-3 December 2003, Auckland, New Zealand. Retrieved from https:// bit.ly/2vFBzl9.

Verenikina, I. (2010). Vygotsky in twenty-first-century research. In J. Herrington \& B. Hunter (Eds.), Proceedings of World Conference on Educational Multimedia, Hypermedia and Telecommunications (pp. 16-25). Chesapeake, VA: AACE. Retrieved from https://bit.ly/2SDXPES.

Vygotsky, L.S. (1986). Thought and language. Cambridge, MA: MIT Press.

Webb, E.J., Campbell, D.T., Schwartz, R.D., \& Sechrest. (1966). Unobtrusive measures: Nonreactive research in the social sciences. Chicago, IL: Rand McNally College Publishing.

White, T.L., \& McBurney, D.H. (2013). Research methods. Belmont, CA: Wadsworth Cengage Learning.

Winkler, S. (2019). What is the zone of proximal development? Retrieved from https://bit. ly/39IZ9Mn.

Woolfolk, A. (2007). Educational psychology. Boston, MA: Pearson.

Ysseldyke, S. 2004). Assessment in special and inclusive education. Boston, MA: Houghton Mifflin Company.

Zarrillo, J.J. (2012). Teaching elementary social studies: Principles and applications. Columbus, $\mathrm{OH}$ : Pearson. 



\title{
The Role of Authentic School Leaders in Promoting Teachers' Well-Being: Perceptions of Israeli Teachers
}

\author{
By Yaffa Buskila ${ }^{+} \&$ Tamar Chen-Levi ${ }^{*}$
}

\begin{abstract}
This study aims to explore teachers' perceptions of the role played by school principals in promoting teachers' well-being. The teachers in Israel have a low professional self-image and work under stressful conditions. Psychological wellbeing combines a good feeling with effective functioning and promoting wellbeing can enhance efficacy at work. This is a qualitative study, with a personal interpretive paradigm of teachers' reflections. Data was collected from 53 teachers and analyzed in a four-stage process: condensing, coding, categorizing, and theorizing. The study was based on the planned theory (Ajzen \& Fishbein, 1980), and the data was encoded and categorized according to the Goleman, Boyatzis and McKee (2004) emotional intelligence (EI), leadership competence which founds to enhance well-being and effectiveness at work. Findings indicate that school principals can play an important role in promoting teachers' wellbeing by displaying relationship management, which generates the highest level of EI: Creating a positive emotional climate, keeping relationships on the right track, and demonstrating genuine concern for teachers. Understanding the importance of EI and mastering it by educational leaders is important for promoting well-being. It is significant for the positive functioning of the teachers and school system. This study contributes to the epistemology of promoting teachers' well-being and developing EI by educational leader.
\end{abstract}

Keywords: School principals, teachers' well-being, emotional intelligence

\section{Introduction}

The teaching profession is considered to be highly stressful in many places in the world (Jepson \& Forrest, 2006) and in Israel as well. There are many reasons for this stress but one of the prominent ones is the neoliberal ideology that advocated for competition, accountability, equality and more (Carnoy, 1995). Stress is a negative phenomenon that develops under conditions of uncontrollable, prolonged and increased pressure. It is defined as a psychological and emotional reaction to imbalance between requirements and the ability to fulfill them (Hakanen, Bakker, \& Schaufeli, 2006). It has side effects in terms of health, adverse results at work, and the reduction of job satisfaction (Bellingrath, Weigl, \&Kudielka, 2008). In Israel, the stressful conditions affect the whole education system and cause teachers and school principals to leave the profession (Oplatka, 2017), further exacerbating the situations. There is a shortage of 3,000 teachers in the Israeli education system due to stress and burnout (Datal, 2019). This scarcity of teachers is not only an Israeli problem; it exists in many other places as well

${ }^{+}$Lecturer, Orot Israel College of Education, Rehovot, Israel.

"Lecturer, Department of Education, Bar-Ilan University, Ramat Gan, Israel. 
such as England, Switzerland, Scotland, Australia, New Zealand, USA and Germany (Shnider Levi, 2016), and even in East Asia (Bas, 2011).

Stress has a negative effect on the well-being of individuals and on the organization as a whole (O'Driscoll \& Cooper, 1996). The World Health Organization (WHO) has defined positive mental health as "a state of Well-being which the individual realizes his or her own abilities, can cope with the normal stresses of life, can work productively and fruitfully and is able to make contributions to his or her community" (WHO, 2001).

Ajzen \& Fishbein (1980) developed a planned behavior theory that reveals strong connections between perceptions, attitude and behavior. Recent studies have proven the significance of value-based leadership, through the concept of authentic leadership. Authentic leaders are among the prominent kinds of school leaders that is considering attitude and traits that affects behavior. Authentic leadership is defined as leadership which promotes a positive attitude as well as moral and ethical perspectives, and is positively related to organizational outcomes such as job satisfaction and work performance (Bird, Wang, Watson \& Murray, 2009; Shapira-Lishchinski \& Tzemach, 2014).

However, little research has been conducted on the role of authentic leaders in promoting teachers' well-being in the era of neoliberal reforms and on how this is actually done. There is also very little research on how leaders' behavior affects teachers' emotional processes (Cliffe, 2011). Israel is an interesting case to study in this context, because like many other countries in the world it is taking part in the neoliberal reforms, however, despite the huge efforts it has made in the hope of improving the educational system (Berkovich, 2014) - it has had no success. It is interesting to study teachers' perspectives since they are those who stand in the frontline and are required to work under stressful conditions (Oplatka, 2017). Thus, we believe that they know better than others what is good for them and what their perceptions are concerning the role of school principals in promoting their well-being at work.

The purpose of our study is to construct a new body of knowledge compiled from teachers in Israel on how they perceive the role of school principals as promoting their well-being. Our research question is: What are teachers' perceptions regarding the role of school principals in promoting teachers' wellbeing, and how is this to be done?

Since stress, which is a psychological and emotional reaction (Hakanen, Bakker, \& Schaufeli, 2006), can be managed by developing well-being, we will connect the planned theory of Ajzen \& Fishbain (1980) for predicting authentic leaders' behavior toward teachers to theories that have reported on developing well-being through emotional and social aspects of leaders' behavior (Brotheridge \& Lee, 2008). 


\section{Literature Review}

\section{Stress in the Teaching Profession}

There is growing evidence indicating that the teaching profession is stressful (Jepson \& Forrest, 2006). In Israel it is even considered to be highly stressful for many reasons, among which are the neoliberal ideology of economy competition, accountability, and equality (Carnoy, 1995), as well as other demands that have evolved over recent years (Oplatka, 2017). All these factors, together with the pressure to improve students' achievements (Bogler \& Nir, 2014), have pushed Israeli policymakers to suggest the recent educational reforms Ofek Chadash ("New Horizon") and Oz LaTmura ("The Courage to Change"). These reforms have increased stress in the whole education system in Israel and on teachers as well, provoking negative emotions and responses. Teachers are also required to give in written reports on varied issues on a daily basis, which burdens them with additional stress, causing them much frustration and making them feel like clerks (Schechter, 2015). They complain about the scarcity of breaks between lessons, working under poor physical conditions and also working long hours compared to the number of hours they used to work before. They are also expected to work from home for the benefit of the school, thus arousing conflict between work demands and family demands (Buskila \& Chen Levi, 2020).

These stressful conditions affect the whole Israeli education systems and cause teachers and school principals to leave the profession (Oplatka, 2017). In May 2019 the Israeli State Comptroller Report published the fact that there is a shortage of 3,000 teachers in the country (Datal, 2019). Scarcity of teachers due to stress is not an exclusively Israeli problem: in England the teaching profession stands highest on the list of stressful professions. In Switzerland, Scotland, Australia and New Zealand, about $80 \%$ of teachers suffer from work overload. In Israel, USA and Germany, about $50 \%$ of teachers leave the profession after 5 years (Shnider Levi, 2016), and in East Asia as well teachers leave the profession due to pressure and burnout (Bas, 2011).

Stress is a negative phenomenon that develops under conditions of uncontrollable, prolonged and increased pressure. Stress may affect health adversely, affecting work results as well (Bellingrath et al., 2009). It leads to emotional exhaustion which diminishes productivity and damages effectiveness (Niessen, Mader \& Jimmieson, 2017) as well as the quality of teaching (Cherniss, 1980). It also reduces job satisfaction, lowers occupational commitment, results in early burnout (Jepson \& Forrest, 2006) and increases job turnover (Jackson, Swab $\&$ Schuler, 1986). Stress may lead to reduced staff retention and to absenteeism, causing the school additional expenses due to having to pay replacement staff. Stress also has a negative impact on the well-being of individuals and of the organization as a whole (O'Driscoll \& Cooper, 1996). 


\section{Theoretical Framework - The Planned Behavior Theory}

Various theoretical frameworks have been proposed to deal with the psychological processes involved in the attempt to predict and explain human behavior (Ajzen, 1991). Ajzen has found that cognitive self-regulation plays a key role in predicting behavior in organizations or with respect to someone. Together with Fishbein, he developed the planned theory, which is a theory designed to predict and explain human behavior. This theory assumes that human behavior results from cognitive processes, and the "central factor in the planned theory is the individual's intention to perform a given behavior that influences" (Ajzen \& Fishbein, 1980, p. 181). This intention will determine the behavior that will be carried out. According to this theory, school principals' perceptions are connected to their attitudes, and these connections can affect their behavior, which in turn will affect teachers. For example, principals' negative perceptions will lead to negative attitudes and behaviors toward teachers. They can lead to negative feelings giving rise to a mode of functioning that will create stress (Anary, 2011); and on the other hand, school principals' positive perceptions will lead to positive attitudes and behaviors toward teachers.

\section{Authentic Leadership}

The authentic leadership construct has evolved from the positive psychology of leadership forms (Seligman, 2002), which consists of integrity, caring and an ethical attitude toward followers (Avolio \& Luthans, 2006). Authentic leadership has been defined a "process that draws form both psychological capacities and highly developed organizational context, which results in both greater selfawareness and self-regulated positive behavior on the part of leaders and associates, fostering positive self-development" (Luthans \& Avolio, 2003, p. 243). These researchers later fine-tuned their authentic leadership concept by focusing more closely on the core of self-awareness and self-regulation. While the self-regulation process includes internal regulation, balanced processing of information, interpersonal transparency and authentic behavior, authentic leadership also includes high ethical standards, which influence decision-making and behavior in general (Avolio \& Gardner, 2005).

Authentic leadership in education is a combination of values, ethics and moral literacy as applied for leadership development in all school aspects for the best interest of students. It is conceptualized through varied perspectives of psychology, philosophy, critical theory and law (Begley \& Stefkovich, 2007). Authentic leaders reflect on their own inner characteristics such as: (a) Self-awareness regarding their lives and work, their strengths and weaknesses, how others perceive them, and the impact that they have on others; (b) Trust toward others and implementation of transparency, sharing thoughts and feelings with others, and minimizing inappropriate emotions; (c) Ability for objective analysis of data, while being interested in hearing others and taking their opinions into consideration; And (d) High internal moral values combined with the expectation that others 
practice high moral and ethical standards as well (Bird et al., 2009). These traits help authentic leaders to overcome obstacles and difficulties and to solve problem (Leroy, Palanski \& Simons, 2011).

\section{Well-Being}

Well-being is the combination of feeling good and functioning effectively. It is associated with positive emotions, relatively high levels of happiness, and life satisfaction (Huppert, 2009). In the school context, well-being refers to the outcome of a process of acquiring a set of skills to recognize and manage emotions, set and achieve positive goals, appreciate others' perspectives, establish and maintain positive relationships, make responsible decisions, and handle interpersonal situations constructively (Barry, Clarke, \& Dowling, 2017). The promotion of teachers' well-being by school principals plays an important role in enabling teachers to engage in their work effectively (Brotheridge \& Lee, 2008), with higher levels of confidence and commitment (Anari, 2011), as well as assisting them in coping with stress. Elevated well-being also increases job satisfaction, productivity and successful outcomes at school (Durlak, Wiesberg, Dymnici, Tailore E Schellinger, 2011). It reduces absenteeism due to stress-related illnesses, saves money, and presents a more positive image of the profession. It also improves retention of staff and facilitates their recruitment (Jepson \& Forrest, 2006).

In the past there were recommendations to reduce stress through varied means such as: role rotation, changes in the subject-matter to be taught (Friedman\& Kampar, 1994), use of techniques such as time managements or psychological tips that can assist teachers in learning how to deal with stress. Important as these methods were, proof of their efficiency is still rare (Schnider Levi, 2016). Wellbeing was found to be negatively associated with work-family conflict and burnout (Hung, Li, Fang \& Tang, 2019). So, reducing teachers' stress by promoting their well-being is of utmost importance (Montgomery \& Rupp, 2005). Teachers' emotional well-being in school promotes the development of five interrelated sets of cognitive, and behavioral competencies: Self-awareness, self-management, social awareness, relationship skills, and responsible decision-making (Durlak et al., 2015). These competencies were understood by Goleman et al. (2004) as emotional intelligence (EI) competencies.

\section{Emotional Intelligence}

Emotional intelligence (EI) has varied definitions. The term was coined by Salovey \& Mayer who defined EI as "relevant to the accurate appraisal and expression of emotion in oneself and in others, the effective regulation of emotion in self and others, and the use of feeling to motivate, plan, and achieve in one's life" (Salovey and Mayer, 1990, p. 185). Based on the theory that cognitive capabilities are influenced by emotions (Gorge, 2000), Salovey and Mayer claim that emotions and feelings work together. EI is also evident in leadership competencies of primal leaders who excel in the art of relationships, and there are 
many evident ratings the leadership effectiveness through EI (Keer, Garvin, Heaton \& Boyle, 2005).

Goleman et al. (2004) have defined leadership in interpersonal terms and argued that the best focal point for contemplating it is through a set of social skills which can be organized in four clusters and 18 sub-scales: (1) Self-awareness which consists of three sub-scales: self-awareness, accurate self-assessment, and self-confidence; (2) Self-management which consists of six sub-scales: selfcontrol, transparency, adaptability, achievement, initiative and optimism; (3) Social awareness with three sub-competencies: empathy, organizational awareness and service orientation; (4) Relationship-management with five sub-competencies: inspiration, influence, developing others, change catalyst, conflict management, and ability to participate in teamwork and collaboration. Leaders who present these characteristics are able to generate an atmosphere of friendly collegiality and constitute models inspiring respect, helpfulness and cooperation. They draw others into active enthusiastic commitment to the collective effort and build spirit and identity.

All emotional competencies involve some degree of skill in the realm of feelings (Goleman et al., 2004). Emotions are part of each of us and they affect our every conversation, activity and decision (Bradbarry\& Greaves, 2005). They play a critical role in developing and maintaining social relationships. While intellectual capability is the pre-eminent predictor for individual work performance, group performance is more dependent on emotional competencies than on intellectual ones (Ashkanazy \& Dorris, 2017).

\section{The Emotional Role of the School Principal}

Schools are emotional institutions, and emotions play an integral part in most of the processes occurring at school such as teaching, learning and managing (James \& Vince, 2001). However, most principals give priority to administrative work (Grissom, Loeb \& Mitani, 2013) over the interpersonal aspect of school life (Harris, 2002). Recently there is growing recognition of the emotional role of leaders, and of its effect on followers' behavior (Ashkanasy \& Dorris, 2017).

School principals are expected to nurture positive relationships as well as managing their own emotions and those of their employees (Brotheridge \& Lee, 2008). They are also expected to develop sensitivity to the emotional side of school management (Fullan, 1998). Part of nurturing positive emotions is done by being emotionally expressive. School principals who are more emotionally expressive are more charismatic, more likely to generate a positive emotional climate, and better at understanding others' emotions (Oplatka, 2011; Riggio, 2007). Understanding emotions can make people more satisfied, more socially engaged and more productive. Happier people have more social contacts. They give and receive emotional support, which are associated with relatively high levels of psychological well-being (Huppert, 2009). Emotional climate at school includes also emotional vocabulary utilization and has a positive effect on emotional regulation (Berkovich \& Eyal, 2016; Clark, Hype-Hailey \& Kellinher, 2007). It tends to stimulate positive emotions in followers (Bass \& Avolio, 1994) 
and has beneficial effects on the way people perceive and interpret social behavior, as well as on how they initiate social interaction. According to Forgas (2006), people experiencing positive emotions evaluate themselves and others more positively, are more lenient, more confident, more optimistic and more generous in interpersonal situations. Positive emotions also motivate followers to transcend their own personal goals for the interests of the students in the school (Begley \& Stefkovich, 2007).

Thus, we believe that promoting teachers' well-being through developing dimensions of EI can help them to reduce their stress levels or at least to balance stress and bring it to a somewhat normal level. Emotional and social aspects of leaders' behavior might be crucial for individuals to thrive under conditions of moderate levels of emotional exhaustion (Niessen et al., 2017). They have an indirect effect on teachers' emotional reframing of various situations and were also found to provide emotional support to teachers as they enable them to reduce stress which they experience at work (Berkovich \& Eyal, 2017).

\section{Methodology}

This qualitative research comprises a personal interpretive paradigm of teachers' reflections on the role of principals in promoting teachers' well-being in Israel. The value of self-reflection contains experience, cognition and selfunderstanding, which involve emotions. "No laws, structures or mechanisms offer higher explanatory principles or greater predictive power than self-interpretations" (Crotty 2003, p. 60). The present study is designed to provide teachers' rich textual self-descriptions in order to learn more about how they perceive the role of school principals in contributing to teachers' well-being. Maximizing the depth and richness of the data and enlarging the sampling can provide us with a broader perspective (Merriam, 2009).

Participants - The 53 participants were Israeli school teachers who are studying for MA degrees in educational leadership as a prerequisite for being accepted to Avney Rosha, the Israeli Institute for School Leadership. All of these teachers are currently teaching in the public education system and studying at two big colleges in central Israel. Among participants there were 41 Jews and 12 Muslims, 7 of whom were males and 46 who were females, with at least three years of teaching experience. We are seeking to develop new knowledge derived from teachers' perceptions, rather than from school principals, because they are the firsthand sources for this knowledge. As aforementioned, they are those who stand in the front line to deal with the stressful day-to-day school life, and they know better than anyone else what is good for them, what they need and what they expect from their school principal in order to do a better job.

Data gathering-For one of the assignments in the educational leadership course, participants were asked to write self-reflections about their perception of school principals in promoting teachers' well-being. They were asked to describe their perceptions in rich detail, to explain why and how they developed them, and to bring varied examples of their own and their colleagues' experiences in different 
work situations. Participants used a questionnaire guide which instructed them to focus on key questions and sub-questions in order to elaborate on their ideas (Merrian, 2009). Participants had three months to pay attention to and follow up on situations that came up at school between them or their colleague and the school principal. The goal was to discover situations that promote well-being, to describe them in writing, and finally to formulate them into a self-report. All students submitted self-reports with their own perceptions. We informed them that we would use their insights and reflections for research purposes only. In order to maintain confidentiality, their names were changed to pseudonyms.

Data analysis - We translated the data from Hebrew to English and analyzed it in a four-stage process: condensing, coding, categorizing and theorizing. The coding guided us to identify ideas or thematic frameworks from the text which were derived from teachers in order to discover useful information. This information was sorted into meaning units that categorized and classified the material according to the features it represented. In order to construct new knowledge from teachers' perceptions about the role of school principals in promoting teachers' well-being, we took the themes that teachers attributed to school principals as imperative for promoting teachers' well-being, and classified them according to the meaning that Goleman et al. (2004) constructed and described for EI as a primal leadership competence.

\section{Results}

According to perceptions who articulated their thoughts in self-reports, school principals have an important role in promoting teachers' well-being. Thirty teachers out of 53 participants, opined that the role of school principals contains emotional components and 12 argued that emotions, either negative or positive, are contagious. They argued that school principals have to master and demonstrate 47 behaviors, most of which are part of the EI construct formulated by Goleman et al. (2004) as leadership competencies of "Primal Leadership". These EI construct is organized with primary titles, categorized into four clusters: self-awareness, selfmanagement, social awareness and relationship management, and 18 subtitles (pp. 253-256). The authors of this study organized the clusters and competences in a table and embedded in it statements or behaviors that evolved from the selfreports, which the participants related to school principal as promoting teachers' well-being. The number next to each statement notes how many teachers opined it. 
Table 1. School Principals' Behavior that Creates Well-Being

\begin{tabular}{|c|c|c|c|}
\hline Self-Awareness & Self-Management & $\begin{array}{l}\text { Social } \\
\text { Awareness }\end{array}$ & $\begin{array}{l}\text { Relationship } \\
\text { Management }\end{array}$ \\
\hline $\begin{array}{l}\text { Emotional Self- } \\
\text { awareness } \\
\text { Guiding values - } 4\end{array}$ & $\begin{array}{l}\text { Self-Control } \\
\text { 1. Restraint - } 1 \\
\text { 2. Humor - } 2 \\
\text { 3. Authoritative - } 1 \\
\text { 4. Patience - } 2 \\
\text { 5. Being calm - } 1\end{array}$ & $\begin{array}{l}\text { Empathy } \\
\text { 1. Listener }-27 \\
\text { 2. Empathy }-8 \\
\text { 3. Inclusion }-11 \\
\text { 4. Respect others } \\
-6 \\
\text { 5. Sensitive - } 2 \\
\text { 6. Keep equality } \\
\text { and justice - } 6 \\
\end{array}$ & $\begin{array}{l}\text { Inspiration } \\
\text { Role model - } 12\end{array}$ \\
\hline $\begin{array}{l}\text { Accurate Self- } \\
\text { Assessment } \\
\text { 1. Fair and reliable - } 5 \\
\text { 2. Responsible - } 1\end{array}$ & $\begin{array}{l}\text { Transparency } \\
\text { 1. Transparency - } 2\end{array}$ & $\begin{array}{l}\text { Organizational } \\
\text { Awareness } \\
\text { 1. Freedom of } \\
\text { expression - } 17 \\
\text { 2. Bestow } \\
\text { confidence and } \\
\text { stay calm - } 4 \\
\end{array}$ & $\begin{array}{l}\text { Influence } \\
\text { 1. Delegate Authority - } \\
\quad 11 \\
\text { See others positively \& } \\
\text { believe in teachers' ability } \\
\text { \& motivation - } 31\end{array}$ \\
\hline \multirow[t]{4}{*}{\begin{tabular}{l} 
Self-Confidence \\
1. $\quad$ Affable - 4 \\
2. $\quad$ Patient - 2 \\
3. $\quad$ Self- \\
\multicolumn{2}{c}{ confidence - 1}
\end{tabular}} & Adaptability & $\begin{array}{l}\text { Service } \\
\text { 1. Protective, } \\
\text { caring and } \\
\text { treating fairly - } \\
38 \\
\text { 2. Help, support } \\
\text { backup } \\
\text { teachers - } 27 \\
\text { 3. Available, } \\
\text { presence } \\
\text { accessible - } 8 \\
\text { 4. Attune } \\
\text { teachers' needs } \\
\& \text { assuring } \\
\text { having } \\
\text { resources - } 17 \\
\end{array}$ & $\begin{array}{l}\text { Developing Others } \\
\text { 1. Constructive feedback - } \\
19 \\
\text { 2. Reinforce \& appreciate } \\
\text { teachers work \& } \\
\text { cultivate teachers' } \\
\text { ability -46 } \\
\text { 3. Encourage Learning - } 16\end{array}$ \\
\hline & $\begin{array}{l}\text { Achievement } \\
\text { Achievers - } 1 \\
\text { Life Long learner - } \\
14 \\
\end{array}$ & & $\begin{array}{l}\text { Change Catalyst } \\
\text { 1. Overcome barrier \& } \\
\text { solve problems - } 7\end{array}$ \\
\hline & $\begin{array}{l}\text { Initiative } \\
\text { 1. Create challenges } \\
\text { and renewing - } 6\end{array}$ & & $\begin{array}{l}\text { Conflict Management } \\
\text { 1. Understand others - } 5 \\
\text { 2. Shared decision- } \\
\text { making } 13 \\
\text { 3. Create borders \& } \\
\text { authoritative - } 4\end{array}$ \\
\hline & Optimism & & $\begin{array}{ll}\text { Teamwork and } \\
\text { Collaboration } \\
\text { 1. } & \text { Good relationships - } \\
& 20 \\
\text { 2. } & \text { Democrat \& bestow } \\
\text { autonomy - } 22 \\
\text { 3. } & \text { Generate positive } \\
\text { atmosphere \& keep } \\
\text { relationship on right } \\
\text { track - 39 }\end{array}$ \\
\hline
\end{tabular}




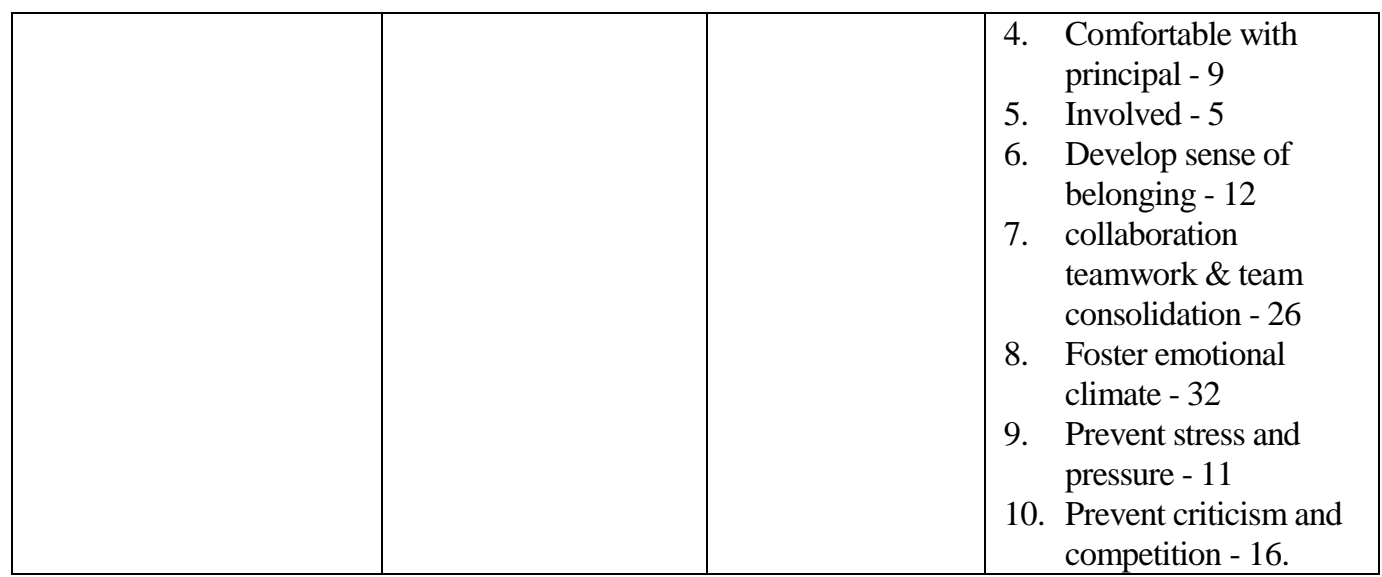

The table is based on the Golman, Boyatzis and McKEE (2004, pp. 253 256) emotional intelligence - leadership competence that was organized by the authors in a chart with primary and secondary titles. Under each title, are embedded competences that teachers attributed to school principals as promoters of well-being. The number of teachers who believe that this competence is important to promote well-being is included.

Table 1 demonstrates the teachers' self-reports articulating their answers about the imperative behaviors of school principals for promoting teachers' wellbeing. The teachers wrote 575 statements describing school principals' expected behaviors. These statements were divided by the authors into 47 sub-titles of Goleman et al. (2004). As can be seen from Table 1, the largest number of selfreports that teachers noted as important falls into the cluster of relationship management which contains 356 statements. The second-highest number of teachers' statements related to school principals' behaviors that express the social awareness cluster, with 171 statements. The third-highest number of teachers' statements related to school principals' behaviors from the self-management cluster with 31 statements. The least behaviors that school teachers relate to principals belong to the self-awareness cluster with 17 statements. Although the voice of each individual teacher is important, we will focus only on competencies mentioned by at least 15 or more teachers, such as social awareness and relationship management.

\section{Promoting Well-being through Social Awareness}

The social awareness cluster contains the ability to be empathetic and to have organizational awareness and a service orientation. There were 60 statements found in the self-reports advocating for the importance of being empathetic: The importance of being a good listener, which is an expression of empathy, was advocated by 27 teachers. For example, Mary, Shellie and Lev claimed that for a principal to be a good listener is important, and Avi added: "Principals must listen to teachers and students in school and care about them."

Twenty-one teachers talked about the importance of being organizationallyaware, and 17 teachers talked about principals who allow freedom of expression which is a part of organizational awareness: Ronnie said, "Being able to have an 
open conversation, allow teachers to talk openly about everything, without criticizing them..." Nava added, "There is a need to develop a culture of dialogue... to encourage open discussions among teachers." Rosa posited: "Freedom of expression can create cohesion among everyone and lead to good decisionmaking."

A school principal who is service-oriented was recommended by 19 teachers. Thirty-eight teachers felt that protecting followers, caring about them and treating them fairly, which all belong to the category of being service-oriented, are important: Bar said: "Being an attentive listener and a caring principal is important." Weiss argued that he would like to work with a principal who is "supportive, human and liberal"; and Robby said that principals should "make it known to teachers that their decisions will be supported." Seventeen teachers felt that principals' being attuned to teachers' needs and assuring that they have all the resources they need to perform their jobs properly are significant factors. Ayala related: "The principal's role is to take care of teachers' needs... and assure that they feel comfortable." Dana added that principals "need to take care of professional and personal needs." Shellie expected school principals to understand that "if I can't come to school one day, that means that I have a problem and I am not trying to avoid coming to work."

\section{Promoting Well-being through Relationship Management}

The main competencies that teachers viewed as essential for promoting teachers' well-being belonged to the cluster of relationship management. In this cluster, there were 356 statements. Thirty-one teachers talked about viewing teachers positively, motivating them, and believing in their abilities as important for promoting their well-being; According to Merry, "principals should develop competencies and believe in workers' abilities." Nava said: "Principals have to believe in teachers' professional ability" and Rosa said, "A good principal is one who can motivate teachers."

Developing others is also a competency that belongs to the relationship management cluster. According to 19 teachers, one of the ways to help teachers grow is by offering them constructive and professional feedback. Tal warns against "giving thoughtless feedback" because it "hurts and creates negative emotions." Another 46 statements reflected the importance of appreciating teachers' work and nurturing their abilities. For example, Chava said, "Teachers have to feel that their work is appreciated." Shira added: "I need to feel appreciated and to hear a good word about my work", and Rosa posited that "Good principals should express supportive feedback and provide recognition for good work". Both Avi and Yafit confirmed that they too believe that "Principals have to believe in teachers" capabilities". Another way to promote teachers' well-being is through encouraging the staff's learning and development: Sara commented: "Learning from others and from their successes is helpful." Also, Shai talked about the importance of "peer learning", and Sam mentioned holding "workshops and training sessions".

Teamwork and collaboration are the most significant components demonstrating the mastering of EI and they were mentioned by teachers as 
promoting their well-being. Twenty teachers talked about the importance of having good relationships with other teachers and school workers: Edi said, "School principals must recognize the importance of good relationships with teachers as an important basis for improving teacher-student relationships and as a key factor for improving teaching and learning." Mary adds that "Teachers generate positive feelings when they are treated warmly by the school principal, and Avi argued that principals must treat teachers "with sensitivity, and maintain good relationships [...] for improving motivation. Twenty-two teachers claimed that teamwork and collaboration are possible only when a democratic atmosphere exists at school and teachers have autonomy at work. Chen and Gila argue that school principals cannot be dictators. As for autonomy, Dana claimed, "Principals who give teachers full autonomy and trust empower them". According to Dekel, "Principals who encourage autonomy and freedom pave the way to good school citizenship".

Generating a positive atmosphere and keeping relationships on a positive track was said to be important by 39 teachers. Twenty-six teachers claimed that collaboration, teamwork and team cohesion are important. According to Miri: "Team cohesion is the school principal's responsibility. It strengthens the teachers' sense of belonging which is so important." Lev spoke about how "cohesion helps in developing an atmosphere of cooperation and team work", Avi added, "Team cohesion can create a sense of self-worth and autonomy". An additional way to develop teamwork and collaboration, through fostering a positive emotional climate, as was reported by 32 teachers, who also explained that school principals should recognize emotions, influence the school's emotional climate, and make time for discussing emotions. According to Edi, principals should "use emotional language and allow people to talk about their feelings". Shira said that principals must be able to "recognize workers' emotions and encourage talking about emotional situations". Yael added: "School principals have to create times for emotional discussion, to exchange emotional experiences, and to be able to ventilate emotions in open conversation". Sixteen teachers emphasized the importance of preventing criticism and competition.

\section{Promoting Well-being through Professionalism}

Apart from the attributes which teachers related to EI as promoting wellbeing, there where additional reflections and thoughts of 15 teachers who used the term "being professional" as a factor for promoting well-being. For example, Chen, Zahava and Yafit talked about the importance of having a principal with good organizational capabilities. Chen said: "Personal, organizational and authentic skills help principals to lead the school responsibly". Josef fondly speaks about "principals who are perceived as experts, consistent, and authentic" and Merry asserts that being professional means "knowing how to set goals and objectives, to follow through until results are seen, to promote excellent teachers and create a positive feeling".

Another aspect of being professional is the ability to create a professional organizational culture. According to Dekel, "Organizational culture is very 
important and is characterized by work processes, work relations among colleagues, and teaching and learning processes." Dor speaks of "developing norms at school to balance emotions [...] it improves our work and prevents burnout". "A stable and strong working culture will not breakdown the school when a principal leaves work", says Miri. According to Yaffa, "principals should be involved in what goes on at school and not isolate themselves. Personal involvement means to come into classrooms and see first-hand what the challenges are and how teachers handle them".

\section{Discussion}

In this study we aimed to construct new knowledge from Israeli teachers' selfreports regarding the way they perceive the role of school principals as promoting teachers' well-being. Results indicated that school principals play a crucial role in promoting teachers' well-being, as confirmed also by Brotheridge \& Lee (2008).

Teachers' work is considered very stressful (Oplatka, 2017) not only in Israel but also in many places in the world. School life in general can be very stressful (Montgomery \& Rupp, 2005). Stress has been found to negatively affect the wellbeing of individuals and of organizations (O'Driscoll \& Cooper, 1996), while wellbeing has been found to help individuals to cope with stress. As well-being is a combination of feeling good and functioning effectively (Hupper, 2009), school teachers need it, and the principal is a central personality at school who has a great deal of influence on teachers' well-being (Montgomery \& Rupp, 2005). The principal can diminish stress and increase well-being, or vice versa. The planned theory assumed that human behavior is a result of cognitive processes, and the central factor in this theory is the "individual's intention to perform a given behavior that influences a behavior" (Ajzen \& Fishbein, 1980, p.181). According to this theory, the way school principals perceive their role is connected to their attitude, and these connections will affect their behavior. A negative attitude on the part of school principals toward teachers can lead them to negative feelings and to functioning in a way that will create stress (Anary, 2011). On the other hand, a positive outlook will lead to a positive attitude promoting positive behavior. Authentic leadership stems from a more positive psychology of leadership (Seligman, 2002). It consists of integrity and a caring and ethical attitude toward followers (Avolio \& Luthans, 2006). Authentic leadership results in greater selfawareness and self-regulated positive behavior on the part of leaders and associates, fostering positive self-development (Luthans \& Avolio, 2003). These behaviors recognized by Goleman et al. (2004, p. 250) as EI, can make leaders highly effective. As mentioned above, EI contains four clusters which rely on each other. Self-awareness is the basic cluster and after mastering it one can go on to master self-management, following which one can proceed to master the second and third clusters, finally reaching the fourth cluster - relationships management -which is the highest level of EI. Most of the teachers' self-reports as to behaviors promoting well-being related to the relationship management cluster, with 356 statements that comprise all the competencies belonging to this cluster. In the second place were 
the social awareness competencies, the third cluster, with 171 statements that comprise all the competencies belonging to this cluster (Goleman et al., 2004).

\section{Emotional Intelligence Endorses Well-being}

Principals perceptions, attitudes and behaviors reflect their relationship management in their organization. Generating a positive atmosphere, keeping relationships on the right track and preserving an emotionally-healthy school climate all affect teachers' feelings, functioning, and general quality of life, thus promoting their well-being (Barry et al., 2017). School principals' emotions are reflected in the teachers' emotions like in a sort of "emotional tango" between two partners. There is a "ripple effect" of principals' emotions on teachers, and they respond accordingly (Goleman, 2006, p. 136). People respond to negative emotions more strongly than to positive ones, so when principals demonstrate a pleasant attitude, teachers respond positively (Sunindijo, Hardikusumo \& Oguniana, 2007).

EI is about knowing how to manage emotions effectively, allowing people to work together toward common goals. There are two patterns of leadership: resonance and dissonance leadership. Resonance leadership occurs when a leader demonstrates a positive emotional mindset, which brings out the best in people. In dissonance leadership, the opposite occurs, undermining the emotional foundations of the organization. A negative emotion of the principal creates a ripple effect on the teachers and can go as far as affecting the students negatively (Goleman, 2006). Thus, EI is important for improving the well-being of both teachers and students, enhancing their social skills and improving achievements (Ciarrochi \& Mayer, 2007).

\section{Fostering Emotional Climate Improves School's Atmosphere}

Fostering emotional climate produces a positive atmosphere that keeps relationships on the right track. A positive emotional climate is based on a rich emotional vocabulary that helps us to understand other people's emotions and improve communication (Barry et al., 2017; Bracket \& Katulack, 2007). School principals who are more emotionally expressive are more charismatic and more likely to generate a positive emotional climate in the school (Riggio, 2007). Maintaining a positive emotional climate improves mood and health, which also strengthen the immune system (Fredrickson, Mancuso, Branigan, \& Tugade, 2000). Such a positive atmosphere improves critical thinking, creative writing and problem-solving skills, and is extremely important in optimizing effectiveness in multiple domains (Bracket \& Katulack, 2007).

A positive emotional climate allows people to discuss even the most sensitive topics openly with others and with their superiors, and in the school context - with the school principal. Fostering a positive emotional climate promotes teamwork in the organization and satisfies employees' basic need to be involved and committed to their work (Northouse, 2004). "Good communication is an art... Business climate... matters more than ever... [it is] a key factor for enhancing good 
relationships, creating an atmosphere of openness and collaboration, and all of these are products of EI" (Goleman, 2006, p. 9). According to Fullan (2001, p. 51) "If moral purpose is job one, relationships are job two, as you cannot get anywhere without them." The ability to understand the triggers of emotions and to communicate them is essential to the success of all professional and personal relationships (Ciarrochi \& Mayer, 2007). According to Sunindijio et al. (2007), $88 \%$ of project managers spend more than half of their working time interacting with others. Thus, their study concludes: Open communication is a key factor in organizational success as it opens up the possibility of getting the best from people. Creating a positive emotional climate means that leaders care for followers, protect them and treat them fairly. It is a product of how well one understands people and is attuned to their needs (Bradberry \& Greaves, 2005).

\section{Being attuned to Teachers' needs}

School principals who are attuned to teachers' needs contribute positively to the emotional climate of the school as a whole. Teachers' needs encompass a wide range of emotions - both professional and personal. Sometimes listening to a teacher can enhance the emotional climate in the school and create an environment that fosters care and attention (Barcket \& Katulak, 2007). Todd (2003) defined listening as a mode of rationality, which creates the possibility of being open to change and to learning from others. By listening attentively, one can hear more than is being said. This kind of listening is more than a regular dialogue. It enables us to learn from others and to be transformed by this learning. Active listening to subtle communication is a manifestation of being empathetic, which is an integral part of the emotional climate created characteristic of an EI atmosphere (Barcket \& Katulak, 2007). Empathy is our social radar and being empathetic means having the ability to sense and understand what others feel without them having to express their feelings in words, and taking an active interest in their concerns (Goleman, 2006). Covey (2004) explains that whenever we attempt to serve human needs, our relationships improve and deepen.

Teachers' needs are varied and can be pedagogical, technical or personal. Crises at home can easily affect performance at school as recalled by one of the teachers. She recounted a crisis of a homeroom third-grade teacher who had 37 students in her class: "One day two students ran to the principal in the middle of a lesson, telling her that their teacher was crying in class. The principal discovered that the teacher's husband had recently left her. She had no money for psychological assistance and no family to help her, and she was alone with two young children. The principal decided to offer her help from the school psychologist, although the responsibility of the school psychologist is primarily toward the students, or toward teachers in the context of helping them cope more effectively with students. This particular principal understood that by assisting the teacher, she was also helping 37 students and preventing a crisis at school with the students' parents and with the school board in the middle of the year".

Another example relates to a new law that was recently been passed in Israel, allowing students with special needs to attend regular classes instead of learning in 
special education classes, and not having special assistance during all school hours. One of the teachers described her frustration at not being able to teach, after investing long hours of preparation in a special lesson aimed at arousing her students' interest and curiosity, because of an unexpected situation with a specialneeds student in her class. She described her students' and her own frustration at not being assisted by anyone at the school, which to her felt like a situation that could totally diminish her well-being. Another example related to a technical problem that a teacher had with a computer projector which stopped working. These situations were all frustrating and stressful for teachers and students alike, and an ounce of help at the right moment could have reduced their frustration.

Another issue that school principals must be aware of is the conflict between home and school demands. A recent study published in Israel on the conflict between school and home demands (Buskila \& Chen Levi, 2020) has shown that teachers who feel that their school principals are attuned to their needs and care to prevent this situation will get much more from teachers, which will in turn benefit the school. Being attuned to teachers' needs reduces pressure, stress and chaos, and results in improved teacher well-being, which enables students to benefit from a relaxed teacher. People who are threatened or uncertain physically, socially or emotionally are unlikely to be able to participate fully in learning or working processes (Allen \& Cohen, 2006). Physical needs range from having an orderly and clean space in which one can work, and feeling safe, i.e., unthreatened by any form of bodily harm both at school and in the community. Thus, creating an emotional climate that enables teachers not to feel alone with their problems is valuable. Sometimes the solution for a certain problem may come from another teacher with a helpful idea; sometimes providing a substitute teacher to replace a tired teacher in the classroom, or talking things over to clarify a misunderstanding, or just allowing a teacher to rest and calm down - prove to be significantly helpful.

\section{Practical and Theoretical Implications}

The Israeli education system is stressful for many reasons, including large class sizes, up to as many as 40 students per class. Recent reforms have created greater accountability but have also added a huge bureaucratic burden of forms to be filled out by teachers. This situation has had negative consequences for both teachers and principals (Berkovich \& Eyal, 2016; Schechter, 2015). It is thus advisable for school principals to be more aware of the fact that teachers' wellbeing fosters professional effectiveness, helping individuals to cope with stress, work productively, and contribute to the school and to the community. School principals will do well to grow more aware of the significance of EI, which can make them more highly effective as leaders and assist them in promoting teachers' well-being (Barry et al., 2017; Goleman et al., 2004). Moreover, if school principals and policy-makers try to diminish teachers' stress and provide them with more assistance, they will most likely promote their well-being. Universities, colleges and staff development trainers may benefit from including EI curriculum and well-being curriculum in educational leaders' training. 


\section{Limitations of the Study and Suggestions for Further Research}

The small size of our sample - 53 participants - may be one of the limitations of this study. A small sample can affect the feasibility of generalizing findings (Crotty, 2005). There is an inherent challenge in conducting research on a broad topic such as teachers' perceptions about their own well-being. Another limitation pertains to the fact that the research has been done in Israel and therefore its results may have been affected by the Israeli culture, including its organizational and managerial characteristics. Additional implications are related to the fact that the self-reports have been given by teachers from public schools, thus our findings and results may not be relevant to private schools or to other sorts of schools with different cultures and ideologies in Israel.

This study illustrates the need for further research concerning the promotion of teachers' well-being by school principals from the school principals' viewpoint. Similar cross-cultural studies from other countries should address this theme in order to provide a cross-cultural perspective.

\section{Bibliography}

Ajzen, I. (1991). The theory of planned behavior. Organizational behavior and human decision processes, 50, $179-2011$.

Ajzen, I., \& Fishbein, M. (1980). Understanding attitude and predicting social behavior. Englewood Cliffs, NJ: Prentice-Hall.

Allen, J., \& Cohen, J. (2006). Emotional intelligence in classrooms and in schools: What we see in the educational setting. In K. R. Murphy (Eds.). In K. R. Murphy (Eds.), A critique of emotional intelligence, (p.p. 125 - 139). Pennsylvania State University.

Anari, N. N. (2011). Teachers: emotional intelligence, job satisfaction and organizational commitment. Journal of Workplace Learning, 24, 259 - 269.

Avolio B. J. \& Gardner, W. L. (2005). Authentic leadership development: Getting to the root of positive forms of leadership. Leadership Quarterly, 16: 315 - 338.

Avolio B. J. \& Luthans, F. (2006). The high impact leader: Authentic, resilient leadership that gets results and sustains growth. New York: McGraw-Hill.

Ashkanasy, N. M., \& Dorris, A. D. (2017). Emotions in the workplace. Annual Review of Organizational Behavior, 4, 67-90.

Barry, M. M., Clarke, A. M. \& Dowling, K. (2017). Promoting social and emotional wellbeing in schools. Health Education, 117 (5), 434 - 451.

Bas, G. (2011). Teacher student control ideology and burnout: Their correlation. Australian. Journal of Teacher Education, 36(4) 6, 84 - 94.

Bass, B.M. \& Avolio, B.J. (1994). Improving Organizational Effectiveness through Transformational Leadership, Sage, Thousand Oaks, CA.

Begleym P. T., \& Stefkovich, J. (2007). Integrating values and ethics into post-secondary for teacher development: Principals, concepts and strategies. Journal of Educational Administration, 45, 398 - 423.

Bellingrath, S., Weigl, T., \& Kudielka, B. M. (2008). Chronic work stress and exhaustion in associated with higher allostatic load in female school teachers. Stress, 12(1), 3748.

Berkovitch, I. (2014). Neo-liberal governance and the new professionalism of Israeli principals. Comparative Education Review, 58(3) 428 - 456. 
Berkovich, I. \& Eyal, O. (2017). The mediating role of principals' transformational leadership behaviors in promoting teachers' emotional wellness at work: a study in Israeli primary schools. Educational Management Administration \& Leadership, 45(2), $316-335$.

Berkovich, I. \& Eyal, O. (2016). Emotional reframing as a mediator of the relationships between transformations school leadership and teachers' motivation and commitment. Journal of educational Administration, 55 (5) 450 - 468.

Bird, J. J., Wang, C., Watson, J., \& Murray, L. (2009). Relationships among principal's authentic leadership, teacher trusts and engagement levels, Journal of School Leadership, 19, 153 - 171.

Bogler, R., \& Nir., A. (2014). The contribution of perceived fit between job demands and abilities to teaches' commitment ad jo satisfaction. Educational Management Administration and Leadership, 43(4), 541 - 560.

Brotherige, C. M., \& Lee, R.T. (2008). The emotions of managing: An introduction to the special issue. Journal of Managerial Psychology, 23 (2) 108 - 117.

Brackett, M. A. \& Katulal, N. A. (2007). Emotional Intelligence in the classroom: skillBased Training for teachers and students. In J. Ciarochi \& J. D. Mayer (Eds.), Applying Emotional Cognition (pp 1 - 27). NY: John Psychology Press Taylor \& Francis Group.

Buskila, Y., \& Chen Levi, T. (2020). Teachers without air: Mapping the stress causes of Israeli teachers in their work. Gilui Daat.(Hebrew).

Bradbarry, T. \& Greaves, J. (2005). The emotional intelligence quick book. New York: Fireside.

Carnoy, Martin, (1995). Structural adjustment and the changing face of education. International Labor Review, 134(6), 653 - 673.

Cherniss, C. (1980). Professional burnout in human service organizations. New York: Praeger

Ciarrochi, J. \& Mayer, J. D. (2007), Introduction. Applying emotional intelligence. New York, Psychology press. p. XII.

Clarke, C., Hype-Hailey, V., \&Kellinher, C. (2007). Being real or really being someone else? Change, managers and emotion work. European Management Journal, 25 (2) $93-103$.

Cliffe, J. (2011). Emotional Intelligence: A study of female secondary school head subordinates. Educational Management Administration and Leadership 39(2): 205 2018.

Covey, R. S. (2004). The $8^{\text {th }}$ habit: from effectiveness to greatness. New York: Free press.

Crotty, M (2003). The Foundations of social research: Meaning and perspective in the research process. Thousand Oaks, Ca, Sage.

Detal Lior, (May 6, 19). Auditor's Report: How to Raise a Lost Generation: Shortage of 3000 Teachers while those teaching are unqualified. Retrieved at 2.12.19 from https://www.themarker.com/news/בeducation/1.7206718

Durlak, J. A., Weisberg, R. P., Dymnici, A. B., Tailore R. D. and Schellinger K. B. (2011). The impact of enhancing students' social and emotional learning: a meta-analysis of school based universal intervention. Child Development, Vol, 82, 1, 204 - 432.

Fullan, M. (1998). Leadership for the $21^{\text {st }}$ century: Breaking the bonds of dependency. Educational Leadership, 55 (7), 45 - 51.

Fullan, M. (2001). Leading changes in a culture of change, 51 - 76. Sun Francisco, JossayBass.

Forgas, J.P. (2006). Affective influences on interpersonal behavior: Towards understanding the role of affect in everyday interactions. In J.P. Forgas (Ed.), Affect in social thinking and behavior (pp. 269-290). New York: Psychology Press. 
Friedman, I., Kemper, C., (1994). Preparations for treatment and relief of stress and burnout in teaching. Jerusalem: Henrietta Szold Institute. (Hebrew).

Fredrickson, B.L., Mancuso, R.A., Branigan, C., \& Tugade, M. (2000). The undoing effect of positive emotions. Motivation and Emotion, 24, 237-258.

George, J.M. (2000), "Emotions and leadership: the role of emotional intelligence", Human Relations, Vol. 53, pp. 1027-55.

Goleman, D. (2006). Working with emotional intelligence. New York: Bantam books

Goleman, D., Boyatzis, R., \& McKee, A. (2004). Primal leadership: realizing a power of emotional intelligence. Boston, Massachusetts: Harvard Business School Press.

Grissom, J. A., Loeb, \& S. \& Mitani, H. (2013). Principal time management skills: explaining patterns in principals' time use and effectiveness Stanford University: Center for Education Policy.

Hakanen, J. J., Bakker, A. B., \& Schaufeli, W. B. (2006). Burnout and work engagement among teachers, Journal of School Psychology, 43, 495 - 513.

Harris, L. C. (2002). The emotional labor of barristers: An exploration of emotional labor by status professionals. Journal of Management Studies, 39 (4) 553 - 584.

Huppert, F. A. (2009). Psychological well-being: evidence regarding its cause and consequences. Applied Psychology: Health and well-Being. 1. (2). 137 - 164.

Hung, S.L., Li, R.H., Fang, S.Y., \&Tang, F.C. (2019). Well-being: Its relationship with work to family conflict and burnout among males and femals. Public Health, 16(13), 2291. Retrieved from: https://www.mdpi.com/1660-4601/16/13/2291/htm

Jackson, S. E., Schwab, R, L, \& Schuler (1986). Toward and understanding the burnout phenomenon. Journal of Applied Psychology, 71, 639 - 640.

James, C. \& Vince, R. (2001). Developing the leadership capability of headteachers, Educational Management, Administration \& Leadership, 29(3), 307 - 317.

Jepson, E. \& Forrest, S. (2006). Individual contributory factors in teachers stress: The role of achievement striving and occupational commitment. British Journal of Educational Psychology, 76, 183 - 197

Keer, R., Garvin, J., Heaton, N., \& Boyle. R. (2005). Emotional intelligence and leadership effectiveness School. EI and leadership effectiveness. Pp. 265 - 278. Retried from: www.emeraldinsight.com/0143-7739.htm

Kyriacou, C. (2001). Teacher stress: Directions for future research. Educational Review, 53 (1) 27 - 35.

Leory, H., Palanski, M. E., \& Simons, T. (2011). Authentic leadership and behavioral integrity as drivers of follower commitment and performance. Journal of Business Ethics. Advanced online publication. Doi:10.1007/s10551-011-1036-1

Luthans, F. \& Avolio, B.J. (2003). Authentic leadership development. In K. S. Camron, J. E. Duttton, \& R. E. Quin (Eds.), Positive organizational scholarship: 241 - 258. San Francisco: Berrett-Koehler.

Merriam, S. B. (2009). Qualitative Research: A guide to design and implementation. San Francisco: Jossey-Bass.

Montgomery, C. \& Rupp, A. A. (2005). A Meta-analysis for exploring the diverse causes and effects of stress in teachers. Canadian Journal of Education. 29(3) 458 - 486.

Niessen, Mader, Stride \&Jimmieson, (2017). Thriving when exhausted: The role of perceived transformational leadership. Journal of Vocational Behavior. 103(2017) 41 $-51$.

Northouse, P. G. (2004). Leadership theory and practice, India: Sage publication.

O'Driscoll, M. P., \& Cooper, C. L. (1996). Source and management of excessive job stress and burnout. In P. Warr (Ed.). Psychology at Work $\left(4^{\text {th }}\right.$ ed.) $182-223$. Penguin Books: London. 
Oplatka, I. (2017). A new look on OfekChadash (The New Horizon) reform, HedHachinuch, 5, 98 - 99. (Hebrew).

Oplatka, I. (2011). The dynamic nature of emotions in the educational leadership: Lessons from the career stories of Israeli late career principals. In Day C. Chic Lee J. (eds). New understanding of teachers works. Dordrecht, Netherlands: Springe. 187 - 204.

Riggio, R. E. (2007). The Emotional and social intelligences of effective leadership: An emotional and social skill approach. Journal of managerial Psychology, 23(2), 341 360.

Salovey, P. and Mayer, J. (1990), "Emotional intelligence", Imagination, Cognition, and Personality, Vol. 9 No. 3, pp. 185-211.

Schecter, C. (2015). Let Us lead! School principals at the forefront of reforms. Tel Aviv: Ramot publications, Tel Aviv University. (Hebrew).

Seligman, M. E. P. (2002. Authentic happiness: Using the new positive psychology to realize your potential for lasting fulfillment. New York: Free Press.

Shapira- Lishchinski, O. \& Tzemach, S. (2014). Psychological empowerment as a mediator between teachers' perceptions of authentic leadership and their withdrawal and citizenship behavior. Educational Administration quarterly. 1 - 38 .

Schneider-Levy, L. (2016). Impact of Inquiry Based Stress Reduction (IBSR) on teacher burnout and mental well-being. (PhD dissertation) Tel Aviv University. (Hebrew).

Sunindijo, R. S., \& Hardikusumo, B. H. Y., \& Oguniana, S. (2007). Journal of Management in Engineering, 23 (4), 166 - 170.

Todd, S. (2003). Learning from others, New York: university of New York Press.

World Health Organization (2001). The world health report-mental health: New understanding, new hope. Geneva: World Health Organization. 


\title{
An Evaluation Constructivist Approach in High School Teaching Process: A Scale Development and Validation
}

\author{
By Dolgun Aslan*, Seyfettin Arslan ${ }^{\dagger} \&$ Hasan Aydin ${ }^{ \pm}$ \\ The purpose of this study was to evaluate the educational process of students in \\ terms of fundamental principles and approaches based on the constructivist \\ approach in Turkey. In this study, which was carried out using quantitative \\ methods, the internal consistency coefficient of the scale developed was \\ estimated to be high. Cronbach's alpha values ranged between $\alpha=.86$ (teaching \\ process), and $\alpha=.69$ (gains), and the alpha value for the total scale was calculated \\ as $\alpha=.75$. The population of the research comprised students continuing their \\ education in three public and three private science high schools in Istanbul. The \\ initial number of items in the student scale was 25 . As a result of the pilot test, \\ the student scale was reduced to 19 Items. In the exploratory factor analysis of \\ the scale used in this study 5 factors emerged.
}

Keywords: constructivist, educational process, evaluation, high school, science, scale development.

\section{Introduction}

Although Turkey has used the constructivist approach in the development of its curriculum since 2005, the last place finish among 34-member countries of Organization for Economic Cooperation and Development (OECD) in the field of education shows that Turkey is facing a severe problem. Many studies have found that the Turkish Education System still faces acute issues in terms of its curricula and the desired results for education have not been achieved (Aslan \& Aydin, 2013). Güneş and Baki (2011) used the case study method and suggested that many factors prevented achieving the desired results in the teaching-learning process. In their research, they stated that a lack of infrastructure, crowded classrooms, and the inadequacy of teaching hours prevented the utilization of the teaching process according to the constructivist approach principles.

Therefore, today, the Turkish Education System needs to solve the problems related to the implementation of the constructivist approach forming the basis of the current teaching processes. To do so, a determination of why the desired gains cannot be achieved and which factors prevent their achievement is required.

Turkey has been interested in the changes and developments observed at the global level, and the educational structure is being restructured in the light of these and shortcomings are being determined, and attempts are being made to correct

\footnotetext{
*Independent Researcher, Turkey.

${ }^{\dagger}$ Independent Researcher, Germany.

${ }^{ \pm}$Associate Professor of Multicultural Education, Florida Gulf Coast University, USA.
} 
them. The changes observed in Turkey's population structure, family characteristics, social structure, consumption methods, and political, social, scientific and technological structure have forced the structure of the education system to change, as well. As a result, drastic changes in the educational system and the need for Turkey to align with global developments are necessary (MOE, 2005). Thus, the new Turkish curriculum has been tried to meet these needs. At this point, educational philosophies, teaching theories, contemporary teaching principles, common targeted skills, and intermediary disciplines that are considered necessary have been utilized.

The purpose of this paper is to investigate Turkish education system, to determine the attitudes towards the constructivist approach in the context of the data, to examine the teaching process based on the constructivist approach according to the emerging learning products, to reveal how the science high school curriculum is evaluated in line with the views of students, to determine the deficiencies and mistakes in the teaching process, and to contribute to the formation of a better teaching-and-learning process.

\section{Literature Review}

Sönmez (2008) emphasized that the constructivist approach stemmed from Dewey's philosophical understanding and educational views, Piaget and Vygotsky's views on human biological characteristics, cultural structures, social context and linguistic development, and Bruner and Aulowerel's ideas about learning. Dewey (1939) rejected the invariance and objectivity of knowledge and stated that undertaking research and investigation was necessary. $\mathrm{He}$ also dismissed the role-learning based education system and noted that education should be seen as life itself, not as preparation for life. Dewey expressed critical opinions in determining the basic principles of constructivism (Colburn, 2000; Hall \& Quinn, 2014; Mahoney, 2004).

The constructivist approach accepts aspects of learning (rather than its being taught), learner autonomy, experiences in learning, primary sources of information, the necessity of the fact that knowledge should be seen as a process of meaning formation and the fact that knowledge does not depend on objective reality (Aydin, 2014; Driscoll, 2000). In addition, this learning theory is based on supporting the natural curiosity of humans and a consideration of how learning is done, that the context is a determinant in learning and that the participation of the students under teacher guidance is meaningful (Glasersfeld, 1989; Huang, Rauch, \& Liaw, 2010; Piaget, 1964; Vygotsky, 1997). In light of these considerations, the constructivist approach considers individual experiences, context, subjective values, and facilitator role of teachers is vital.

Similarly, Kaptan and Korkmaz (2001) emphasized that learning should be seen as a process in which experimental, subjective, and individual efforts are carried out. In terms of constructivism, Fer and Cirik (2007) said that, in general, learning theory explains how an individual structures information in his/her learning process, what activities are performed in this structuring process and what 
factors affect this structuring process. As Akınoğlu (2003) stated, knowledge is internalized by an individual's attribution of meaning to knowledge in a unique way based on his/her experiences, observations, and logical analyzes. Parallel to these opinions regarding the position and role of the student in the learning process, Asan and Güneş (2000) argued that students should be given opportunities to participate in activities, to ask questions about a problem and to achieve the results by utilizing student-centred activities.

Thanasoulas (2002) emphasized that, in constructivism, students carry out and acquire new learning by combining new acquisitions with what they hear, read, and see based on individual experiences. According to Woofter (2019), and Halpern (2017) students should be allowed to reveal their potential by enabling them to bear the responsibility of learning through concrete experiences and should be encouraged at the point of self-control. In addition, Açıkgöz (2009) stated that teachers should have positive and real expectations of students. Because the characteristics of students greatly influence the expectations of teachers, teachers should provide the opportunity for the development of student selfconfidence and belief in success. The constructivist approach seeks to offer approaches that will provide opportunities for students to meet expectations, to be motivated, and to increase their interest in internal dimensions will play a critical role in achieving educational goals and creating an efficient process (Aslan \& Aydin, 2015; 2016; Lapaglia, 2018).

This study was designed to develop a scale to evaluate the teaching process in science high schools in terms of the basic principles and values of the constructivist approach. Answers for the following questions were sought to achieve this objective.

1. What are the results of the exploratory factor analysis of the Scale for Evaluation of Teaching Process in Science High Schools in terms of the constructivist approach?

2. What are the results of the reliability test for the Scale for Evaluation of Teaching Process in Science High Schools in terms of constructivist approach?

3. What are the common load values of all items in the Scale for Evaluation of Teaching Process in Science High Schools in terms of the constructivist approach?

\section{Method}

This study used a quantitative method. According to Yıldırım and Şimşek (2008), reality is based on objective data in quantitative research. The main objective in the quantitative process is to provide an opportunity to present results with quantitative data through the measurement of variables and correlations.

The objective of this current study was to evaluate the teaching-learning process in science high schools in terms of constructivist approach with a 5-point Likert-type scale for statements that the researcher prepared. A scale comprising 
25 statements was developed to determine the opinions of students. In this process, faculty members who were experts in their fields were asked to examine the items mentioned in the scale to determine if they were in accordance with the underlying philosophy and logic of the constructivist approach and whether students could easily understand them considering the readiness and perception levels of the target audience. After this review, the necessary changes were made.

After the necessary permission was received from the Directorate of National Education, a pilot study was conducted among 255 students in public and private science high schools in Istanbul in the fall semester of 2014-2015. The 5-point Likert type utilized had possible responses ranging from Strongly Disagree (1), Disagree (2), Partially Agree (3), Agree (4), to Strongly Agree (5). An exploratory factor analysis was conducted to the factor structure of the scale, which resulted in 5 factors in the student survey after the pilot study was conducted.

\section{Participants and Sampling}

The sample for this study was selected from three public science high schools (F1, F2, F3) and three private science high schools (ÖF1, ÖF2, ÖF3) and a questionnaire was designed for the students in these high schools. Within the scope of this research, "A Scale for Determining the Views of Science High School Students on Constructivist Approach" was prepared for quantitative research and applied to the selected public and private science high schools in Istanbul. Necessary appointments were made from the science high schools and receipts of permission were presented to the school administrators. In this study, sampling was conducted through Simple Random Sampling. Büyüköztürk (2012) explained that the simple random sampling method was the random selection of sampling units of the population to be examined regardless of any preconditions. The population of this research comprised students in the selected public and private science high schools operating under the Turkish National Education system. The sample of the pilot study included students in the public and private science high schools in Istanbul province, and the response rate was $87 \%$.

The frequency and percentage values of the student dimension related to the pilot scheme are given in Table 1 and Table 2.

Table 1. Frequency and Percentage Values for Gender

\begin{tabular}{|l|c|c|c|}
\hline Group & f & Valid \% & Cum. \% \\
\hline Female & 51 & 20 & 20 \\
\hline Male & 204 & 80 & 100 \\
\hline Total & 255 & 100 & \\
\hline
\end{tabular}

As seen in Table 1, $51(20 \%)$ of the students in the sample group were female, and $204(80 \%)$ were male. 
Table 2. Frequency and Percentage Values for Grade Level

\begin{tabular}{|l|c|c|c|}
\hline Group & f & Valid \% & Cum. \% \\
\hline $10^{\text {th }}$ Grade & 105 & 41.18 & 41,18 \\
\hline $11^{\text {th }}$ Grade & 84 & 32.94 & 74,12 \\
\hline $12^{\text {th }}$ Grade & 66 & 25.88 & 100 \\
\hline Total & 255 & 100 & \\
\hline
\end{tabular}

As can be seen in Table 2, 105 (41.18\%) of the students in the sample group were $10^{\text {th }}$ graders; $84(32.94 \%)$ were $11^{\text {th }}$ graders; and $66(25.88 \%)$ were $12^{\text {th }}$ graders. Because the pilot project was carried out in October of 2015 9th graders were not included because they could not fully comprehend the scale for the teaching process because they were new to their schools.

\section{Data Collection Tools}

In this study, data were obtained through a questionnaire. According to Aydin (2019), a measurement tool is valid only to the extent to which it can measure what it is intended to measure. Thus, a measurement tool should be on a single question basis and in a structure suitable for it as a whole. To achieve the objective of this study, a literature search about constructivist teaching theory was performed, and similar searches were conducted in the context of problems and sub-problems. Also, the opinions of three experts in the field of constructivist learning theory and educational programs and teaching were sought. Additionally, seven people who were continuing their doctoral studies in the field of educational sciences were asked to evaluate the scale.

The scale for determining the opinions of science high school students about the constructivist approach was prepared with a 5-Likert type scale and utilized the categories Strongly disagree (1), Disagree (2), Partially agree (3), Agree (4), Strongly agree (5). To assess the validity and reliability of the scale, 25 items related to the student dimension were determined during the pilot scheme process and then applied. After the pilot scheme, item elimination was carried out during factor analysis, and the number of items on the student scale was reduced to 19 .

\section{Data Analysis and Results}

Cronbach's alpha values for the total consistency and the internal consistency calculated on the items contained in each sub-dimension are given below.

Table 3. Sub-dimensions Determined as a Result of Factor Analysis and Reliability Coefficients of These Dimensions

\begin{tabular}{|l|c|}
\hline Factor & Cronbach's alpha \\
\hline Teacher approaches & .821 \\
\hline Teaching process & .860 \\
\hline Measurement and evaluation & .779 \\
\hline Gains & .691 \\
\hline Content and teaching materials & .701 \\
\hline Total & .753 \\
\hline
\end{tabular}


As can be seen from the data in Table 3, the internal consistency coefficients of the scale except for one factor were found to be high. The Cronbach's alpha values ranged from $\alpha=.86$ (teaching process) to $\alpha=.69$ (gains). Alpha value was calculated as $\alpha=.75$ for the total scale. These values indicate that the internal consistency of the scale is extremely high. Because the internal consistency coefficient for the total of the scale was higher than .70, the boundary value in the sub-dimension of gains was not considered.

This section contains the results obtained from the analysis of the data that were collected in the research with a 5-point Likert scale.

Table 4. The Results of Kaiser-Meyer-Olkin (KMO) Measure of Sampling Adequacy and Bartlett's Test of Sphericity

\begin{tabular}{|l|c|c|}
\hline \multicolumn{2}{|c|}{ Kaiser-Meyer-Olkin (KMO) Measure of Sampling Adequacy } & .832 \\
\hline \multirow{3}{*}{ Bartlett's Test of Sphericity } & Chi-Square Value & 2764.977 \\
\cline { 2 - 3 } & S. Degree & 171 \\
\cline { 2 - 3 } & $\mathrm{p}$ & .000 \\
\hline
\end{tabular}

Table 4 shows that the KMO value was, 832, and the Bartlett value was significant $(\mathrm{x} 2=2764.98 ; \mathrm{p}<.001)$ after item elimination. Büyüköztürk (2012) stated that KMO a value being higher than 50 and Bartlett value being significant confirmed the eligibility of the data for factor analysis. In this context, the sample size and structure were factorable, and the procedures were continued. For this purpose, the results obtained by calculating the common load values obtained by Principal Component Analysis are given in Table 5.

Table 5. Common Load Values

\begin{tabular}{|l|c|}
\hline Item & Extraction \\
\hline $\begin{array}{l}\text { Q2. The gains provide us to improve ourselves in many aspects (cognitive, } \\
\text { affective, psychomotor). }\end{array}$ & .529 \\
\hline $\begin{array}{l}\text { Q3. The activities carried out during the teaching process are able to allow us } \\
\text { to comprehend and apply the information rather than memorizing it. }\end{array}$ & .693 \\
\hline $\begin{array}{l}\text { Q4. We are allowed to obtain the knowledge and skills we need in daily life } \\
\text { during the teaching process. }\end{array}$ & .631 \\
\hline $\begin{array}{l}\text { Q5. We are given the opportunity to practice with different teaching methods } \\
\text { and techniques according to the gains. }\end{array}$ & .680 \\
\hline $\begin{array}{l}\text { Q7. Teaching activities are performed in a way that will provide the } \\
\text { development of our problem-solving skills. }\end{array}$ & .672 \\
\hline $\begin{array}{l}\text { Q8. Teaching activities are capable of developing our questioning and critical } \\
\text { thinking skills. }\end{array}$ & .657 \\
\hline $\begin{array}{l}\text { Q9. Topics (books, workbooks, materials...) contain contents that will allow } \\
\text { us to comprehend and practice the information rather than memorization. }\end{array}$ & .628 \\
\hline $\begin{array}{l}\text { Q10. That there are a lot of topics in the content makes our learning more } \\
\text { difficult. }\end{array}$ & .556 \\
\hline $\begin{array}{l}\text { Q12. The most part of a class hour is not being conducted with the teacher's } \\
\text { course presentation, but in a way that allows for our active participation. }\end{array}$ & .650 \\
\hline Q13. There is no time for implementation due to the intensity of topics. & .542 \\
\hline
\end{tabular}


Q14. Courses are being conducted by discussions, question-answers etc. rather than the transfer of information by the teacher.

Q15. The teaching process is carried out through collaborative processes that allow the sharing of knowledge and skills rather than the presentation of information by the teacher.

Q16. We are given enough opportunities to turn the theoretical knowledge we have gained during the teaching process into practice.

Q19. Teacher gives us the opportunity to discover and comprehend the information with appropriate tips rather than presenting the information as ready.

Q20. The performance and project tasks given in the teaching process do not serve to achieve gains.

Q21. Our performance and efforts in the course are not taken into consideration in the assessment process as much as written and oral exam scores.

Q22. Evaluations are made to measure higher level gains (application, analysis, synthesis, and evaluation) rather than remembering the learned information.

Q24. Since there is no time left for application, homework is given for the activities.

Q25. There are not enough performance-based assessments.

As Table 5 shows, the common load values of all items were more than 50 . The lowest load value obtained was calculated as .501 in the $21^{\text {st }}$ item. Due to the high values, factor analysis was continued at this stage without an item elimination, and the findings of the explained variance amounts and factor numbers are presented in Table 6 .

Table 6. Explained Total Variance Amounts

\begin{tabular}{|l|c|c|c|c|c|c|c|c|c|}
\hline \multirow{2}{*}{ Factor } & \multicolumn{3}{|c|}{ Initial Eigenvalues } & \multicolumn{3}{c|}{ Total Factor Loads } & \multicolumn{3}{c|}{$\begin{array}{c}\text { Totals of Rotated Factor } \\
\text { Loads }\end{array}$} \\
\cline { 2 - 11 } & Tot. & Vari.\% & Cum. \% & Tot. & Vari.\% & Cum.\% & Tot. & Vari.\% & Cum. \% \\
\hline 1 & 6.936 & 36.508 & 36.508 & 6.936 & 36.508 & 36.508 & 3.201 & 16.846 & 16.846 \\
\hline 2 & 1.801 & 9.480 & 45.988 & 1.801 & 9.480 & 45,988 & 2.890 & 15.208 & 32.054 \\
\hline 3 & 1.375 & 7.236 & 53.224 & 1.375 & 7.236 & 53.224 & 2.422 & 12.749 & 44.803 \\
\hline 4 & 1.262 & 6.644 & 59.867 & 1.262 & 6.644 & 59.867 & 2.203 & 11.597 & 56.400 \\
\hline 5 & 1.050 & 5.527 & 65.394 & 1.050 & 5.527 & 65.394 & 1.709 & 8.994 & 65.394 \\
\hline 6 & .928 & 4.883 & 70.277 & & & & & & \\
\hline 7 & .804 & 4.230 & 74.507 & & & & & & \\
\hline 8 & .713 & 3.753 & 78.260 & & & & & & \\
\hline 9 & .667 & 3.510 & 81.770 & & & & & & \\
\hline 10 & .574 & 3.023 & 84.793 & & & & & & \\
\hline 11 & .554 & 2.915 & 87.708 & & & & & & \\
\hline 12 & .493 & 2.593 & 90.301 & & & & & & \\
\hline 13 & .413 & 2.172 & 92.473 & & & & & & \\
\hline 14 & .391 & 2.057 & 94.530 & & & & & & \\
\hline 15 & .337 & 1.773 & 96.303 & & & & & & \\
\hline 16 & .300 & 1.580 & 97.883 & & & & & & \\
\hline 17 & .220 & 1.159 & 99.043 & & & & & & \\
\hline 18 & .164 & .861 & 99.903 & & & & & & \\
\hline 19 & .018 & .097 & 100.000 & & & & & & \\
\hline
\end{tabular}


Table 7. Rotated Component Matrix after Factor Analysis

\begin{tabular}{|c|c|c|c|c|c|}
\hline \multirow{2}{*}{ Item } & \multicolumn{5}{|c|}{ Component } \\
\hline & 1 & 2 & 3 & 4 & 5 \\
\hline $\begin{array}{l}\text { Q14. Courses are being conducted by discussions, question- } \\
\text { answers, etc. rather than the transfer of information by the } \\
\text { teacher. }\end{array}$ & .842 & & & & \\
\hline $\begin{array}{l}\text { Q15. The teaching process is carried out through } \\
\text { collaborative processes that allow the sharing of knowledge } \\
\text { and skills rather than the presentation of information by the } \\
\text { teacher. }\end{array}$ & .729 & & & & \\
\hline $\begin{array}{l}\text { Q12. The most part of a class hour is not being conducted } \\
\text { with the teacher's course presentation, but in a way that } \\
\text { allows for our active participation. }\end{array}$ & .646 & & & & \\
\hline $\begin{array}{l}\text { Q19. Teacher gives us the opportunity to discover and } \\
\text { comprehend the information with appropriate tips rather } \\
\text { than presenting the information as ready. }\end{array}$ & .604 & & & & \\
\hline $\begin{array}{l}\text { Q4. We are allowed to obtain the knowledge and skills we } \\
\text { need in daily life during the teaching process. }\end{array}$ & & .543 & & & \\
\hline $\begin{array}{l}\text { Q7. Educational activities are carried out in a way that will } \\
\text { allow the development of our problem-solving skills. }\end{array}$ & & .790 & & & \\
\hline $\begin{array}{l}\text { Q8. Educational activities are capable of developing our } \\
\text { questioning and critical thinking skills. }\end{array}$ & & .767 & & & \\
\hline $\begin{array}{l}\text { Q3. The activities carried out during the teaching process } \\
\text { are able to allow us to comprehend and apply the } \\
\text { information rather than memorizing it. }\end{array}$ & & .578 & & & \\
\hline $\begin{array}{l}\text { Q16. We are given enough opportunities to turn the } \\
\text { theoretical knowledge we have gained during the teaching } \\
\text { process into practice. }\end{array}$ & & .565 & & & \\
\hline $\begin{array}{l}\text { Q24. Since there is no time left for application, homework is } \\
\text { given for the activities. }\end{array}$ & & .514 & & & \\
\hline $\begin{array}{l}\text { Q22. Evaluations are made to measure higher level gains } \\
\text { (application, analysis, synthesis, and evaluation) rather than } \\
\text { remembering the learned information. }\end{array}$ & & & .849 & & \\
\hline Q25. There are not enough performance-based assessments. & & & .846 & & \\
\hline $\begin{array}{l}\text { Q21. Our performance and efforts in the course are not } \\
\text { taken into consideration in the assessment process as much } \\
\text { as written and oral exam scores. }\end{array}$ & & & .644 & & \\
\hline $\begin{array}{l}\text { Q20. The performance and project tasks given in the } \\
\text { teaching process do not serve to achieve gains. }\end{array}$ & & & & .800 & \\
\hline $\begin{array}{l}\text { Q5. We are given the opportunity to practice with different } \\
\text { teaching methods and techniques according to the gains. }\end{array}$ & & & & .726 & \\
\hline $\begin{array}{l}\text { Q2. The gains provide us to improve ourselves in many } \\
\text { aspects (cognitive, affective, psychomotor). }\end{array}$ & & & & .529 & \\
\hline $\begin{array}{l}\text { Q9. Topics (books, workbooks, materials...) contain } \\
\text { contents that will allow us to comprehend and practice the } \\
\text { information rather than memorization. }\end{array}$ & & & & & .759 \\
\hline $\begin{array}{l}\text { Q13. There is no time for implementation due to the } \\
\text { intensity of topics. }\end{array}$ & & & & & 690 \\
\hline $\begin{array}{l}\text { Q10. That there are a lot of topics in the content makes our } \\
\text { learning more difficult. }\end{array}$ & & & & & .666 \\
\hline
\end{tabular}


As a result of the factor analysis made with principal components analysis by using an Eigenvalue of 1, the initial scale had a five-factor structure. These five factors explained $65.39 \%$ of the total variance. For the first factor, the Eigenvalue was 6.94 , and its factor loading was $36.51 \%$. The difference between the second factor and the loading was very high (approximately $27.03 \%$ ). The following sections of the analysis were carried out on the multifactor structure, and the results obtained by rotating with varimax vertical rotation technique are presented below to examine the factors into which the items were gathered.

When the varimax vertical rotation technique examined the distribution of the items to the factors, all items had more than a $10 \%$ difference $(<.30)$ for more than one factor. This indicated that all items in the scale had a sufficiently distinctive structure. For that reason, factor analyses were ended without item elimination. Table 8 shows the items, and the number of items in the subdimensions is presented below.

Table 8. Sub-dimensions Determined as a Result of Factor Analysis and Items that took Load Values from these Sub-Dimensions

\begin{tabular}{|l|c|c|}
\hline Factor & Number of Items & Item Number \\
\hline 1 & Teacher approaches & $12,14,15,19$ \\
\hline 2 & Teaching process & $3,4,7,8,16,24$ \\
\hline 3 & Measurement and evaluation & $21,22,25$ \\
\hline 4 & Gains & $2,5,20$ \\
\hline 5 & Content and teaching materials & $9,10,13$ \\
\hline Total & & $\mathbf{1 9}$ \\
\hline
\end{tabular}

Table 8 shows the first factor has 4 items (Item 12, 14, 15, and 19); the second factor has 6 items (Item 3, 4, 7, 8, 16, and 24); the third factor has 3 items (Item 21, 22, and 25); the fourth factor has 3 items (Item 2, 5, and 20) and the fifth factor has 3 items (Item 9, 10, and 13). Items 20, 2, and 25 are opposite items for the factor in which they are included. The entire scale has 19 items.

Each factor was titled after examining the items in the related factor. In this context, the first sub-dimension was titled as the teacher approaches subdimension; the second sub-dimension was titled as the teaching process subdimension; the third sub-dimension was titled as the measurement and evaluation sub-dimension; the fourth sub-dimension was titled as the gains sub-dimension, and the fifth sub-dimension was titled as the content and teaching materials subdimension. The increase in scores in all factors and total is regarded as the increase of the related feature. After this stage, reliability analysis was performed for the factors.

Distinctiveness comprises the points obtained by comparing the points of the individuals in the upper and lower quarters $(27 \%)$ of the test using the independent group t-test. The aim is to reveal whether the answer given to that item differentiates between the lower and upper groups and to prove its distinctive power (Ergin, 1995). An independent samples t-test was used to determine whether a significant difference existed between the arithmetic means of the upper 
(27\%) and lower (27\%) groups that were determined according to factor total points. The results are presented in Table 9.

Table 9. Independent Group T-test Results to Determine the Distinctiveness of Scale Items

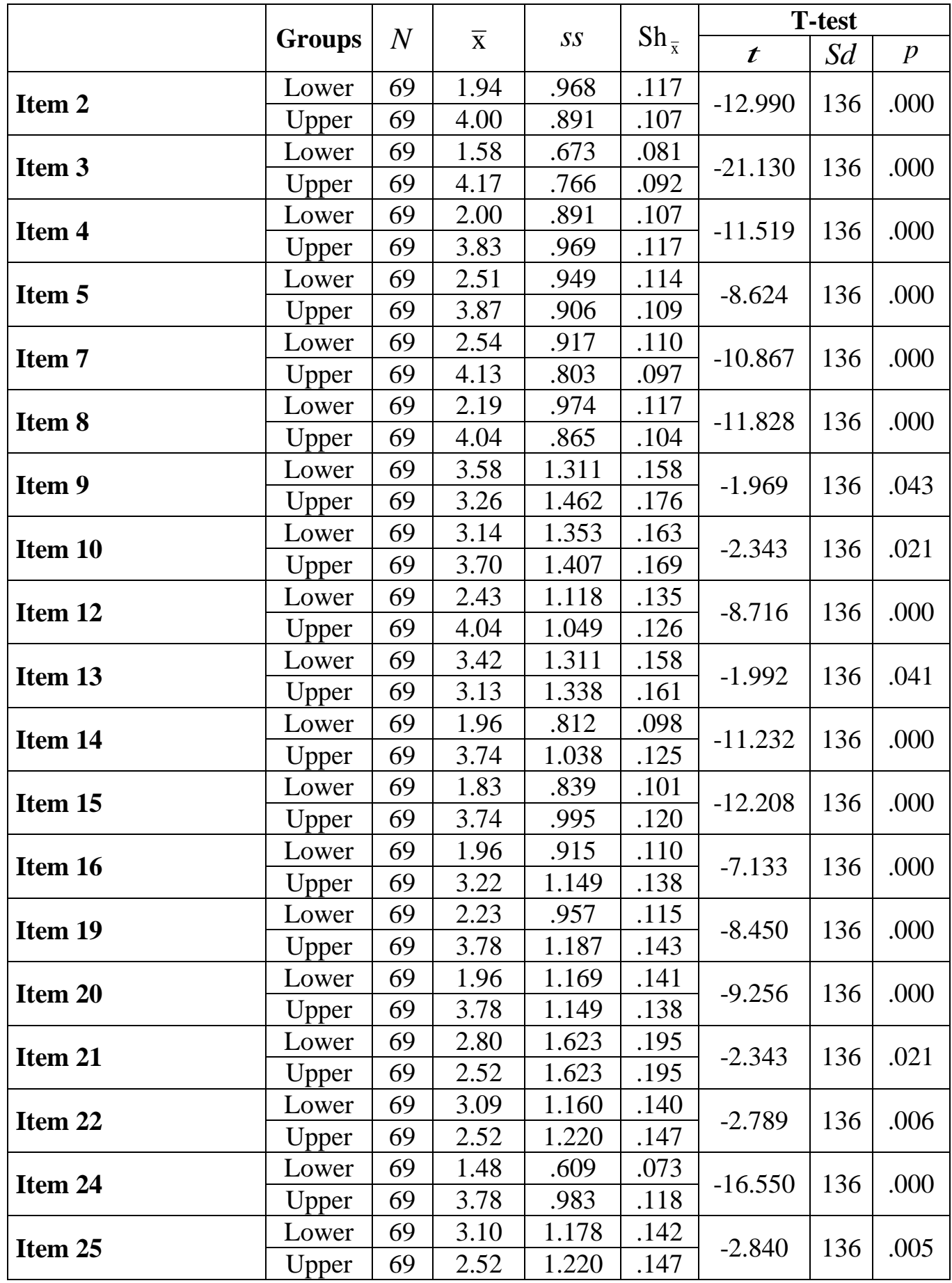

Table 9 shows the results of the independent samples t-test that was performed to determine the distinctiveness of the items and to determine whether a 
significant difference existed between the arithmetic means of the upper (27\%) and lower $(27 \%)$ groups. The differences were found as statistically significant for all groups $(\mathrm{p}<.001)$. These differences were in favor of the upper groups. The obtained results showed that the items of the scale were distinctive. After this result, discriminant analysis was utilized to determine the distinctiveness of the scale sub-dimensions and total points.

Table 10. Independent Group T-test Results to Determine the Distinctiveness of Scale Sub-dimensions and Total Points

\begin{tabular}{|c|c|c|c|c|c|c|c|c|}
\hline \multirow{2}{*}{ Point } & \multirow{2}{*}{ Groups } & \multirow{2}{*}{$N$} & \multirow[b]{2}{*}{$\overline{\mathrm{x}}$} & \multirow[b]{2}{*}{ sS } & \multirow{2}{*}{$\mathrm{Sh}_{\bar{x}}$} & \multicolumn{3}{|c|}{ T-test } \\
\hline & & & & & & $t$ & $S d$ & $p$ \\
\hline \multirow{2}{*}{ LOWER1 } & Lower & 69 & 8.45 & 2.541 & .306 & \multirow{2}{*}{-14.033} & \multirow{2}{*}{136} & \multirow{2}{*}{.000} \\
\hline & Upper & 69 & 15.30 & 3.164 & .381 & & & \\
\hline \multirow{2}{*}{ LOWER2 } & Lower & 69 & 11.74 & 3.248 & .391 & \multirow{2}{*}{-18.548} & \multirow{2}{*}{136} & \multirow{2}{*}{.000} \\
\hline & Upper & 69 & 23.17 & 3.959 & .477 & & & \\
\hline \multirow{2}{*}{ LOWER3 } & Lower & 69 & 4.74 & 1.080 & .130 & \multirow{2}{*}{-39.324} & \multirow{2}{*}{136} & \multirow{2}{*}{.000} \\
\hline & Upper & 69 & 12.77 & 1.308 & .157 & & & \\
\hline \multirow{2}{*}{ LOWER4 } & Lower & 69 & 6.41 & 2.165 & .261 & \multirow{2}{*}{-14.269} & \multirow{2}{*}{136} & \multirow{2}{*}{.000} \\
\hline & Upper & 69 & 11.65 & 2.155 & .259 & & & \\
\hline \multirow{2}{*}{ LOWER5 } & Lower & 69 & 7.22 & 1.653 & .199 & \multirow{2}{*}{-30.010} & \multirow{2}{*}{136} & \multirow{2}{*}{.000} \\
\hline & Upper & 69 & 13.96 & .865 & .104 & & & \\
\hline \multirow{2}{*}{ TOTAL } & Lower & 69 & 45.72 & 3.568 & .430 & \multirow{2}{*}{-32.454} & \multirow{2}{*}{136} & \multirow{2}{*}{.000} \\
\hline & Upper & 69 & 67.78 & 4.375 & .527 & & & \\
\hline
\end{tabular}

Table 10 shows the results of the independent samples t-test that was performed to determine the distinctiveness of the scale's total point and subdimension points and to determine whether there was a significant difference between the arithmetic means of the upper (27\%) and lower (27\%) groups. The differences were found as statistically significant for all groups $(\mathrm{p}<.001)$. These differences were in favor of the upper groups. The obtained results showed that the items of the scale were distinctive. After this result, a calculation of the correlation of scale items with total points was performed. The results of Item-total and Item-remainder analyses that were performed for this purpose are given in Table 11.

As shown in Table 11, all item correlations were significant in the ItemTotal and Item-Remainder analyses. These significance levels were realized at the $\mathrm{p}<.05$ level for items $9,10,13,21,22$, and 25. and at $\mathrm{p}<.001$ level in others. All these results showed that all items were in the same structure. After these procedures, the interfactor correlations were calculated, and the obtained results are presented below in Table 12. 
Table 11. Correlation Results of Item-Total and Item-Remainder

\begin{tabular}{|l|c|c|c|c|c|}
\hline \multirow{2}{*}{ Item } & \multicolumn{3}{|c|}{ Total Point } & \multicolumn{2}{c|}{ Item-Remainder } \\
\cline { 2 - 6 } & $\mathbf{N}$ & $\mathbf{r}$ & $\mathbf{p}$ & $\mathbf{r}$ & $\mathbf{p}$ \\
\hline S2 & 255 & .618 & .000 & .517 & .000 \\
\hline S3 & 255 & .771 & .000 & .701 & .000 \\
\hline S4 & 255 & .684 & .000 & .608 & .000 \\
\hline S5 & 255 & .514 & .000 & .415 & .000 \\
\hline S7 & 255 & .572 & .000 & .481 & .000 \\
\hline S8 & 255 & .610 & .000 & .517 & .000 \\
\hline S9 & 255 & .166 & .020 & .172 & .020 \\
\hline S10 & 255 & .130 & .035 & .130 & .035 \\
\hline S12 & 255 & .569 & .000 & .470 & .000 \\
\hline S13 & 255 & .136 & .030 & .163 & .030 \\
\hline S14 & 255 & .595 & .000 & .504 & .000 \\
\hline S15 & 255 & .655 & .000 & .572 & .000 \\
\hline S16 & 255 & .537 & .000 & .443 & .000 \\
\hline S19 & 255 & .482 & .000 & .374 & .000 \\
\hline S20 & 255 & -.485 & .000 & -.352 & .000 \\
\hline S21 & 255 & -.136 & .030 & -.206 & .030 \\
\hline S22 & 255 & .126 & 045 & .255 & .045 \\
\hline S24 & 255 & .702 & .000 & .617 & .000 \\
\hline S25 & 255 & -.136 & .030 & -.264 & .030 \\
\hline
\end{tabular}

Table 12. Results of Pearson Product-Moment Correlation Analysis to Determine Interfactor Correlations $(\mathrm{N}=255)$

\begin{tabular}{|c|c|c|c|c|c|c|}
\hline & & LOWER2 & LOWER3 & LOWER4 & LOWER5 & Total \\
\hline \multirow{2}{*}{$\begin{array}{l}\text { Teacher } \\
\text { approaches }\end{array}$} & $\mathrm{r}$ & .659 & .499 & .507 & .284 & .713 \\
\hline & $\mathrm{p}$ & .000 & .000 & .000 & .000 & .000 \\
\hline \multirow{2}{*}{ Teaching process } & $\mathrm{r}$ & & .374 & .598 & .304 & .847 \\
\hline & $\mathrm{p}$ & & .000 & .000 & .000 & .000 \\
\hline \multirow{2}{*}{$\begin{array}{l}\text { Measurement and } \\
\text { evaluation }\end{array}$} & $\mathrm{r}$ & & & .395 & .266 & .131 \\
\hline & $\mathrm{p}$ & & & .000 & .000 & .044 \\
\hline \multirow{2}{*}{ Gains } & $\mathrm{r}$ & & & & .231 & .687 \\
\hline & $\mathrm{p}$ & & & & .000 & .000 \\
\hline \multirow{2}{*}{$\begin{array}{l}\text { Content and } \\
\text { teaching materials }\end{array}$} & $\mathrm{r}$ & & & & & .137 \\
\hline & $p$ & & & & & .041 \\
\hline
\end{tabular}

Table 12 shows the results of the Pearson Product-Moment Correlation analysis that was conducted to determine whether a significant correlation exists between the factors. As a result, a positive and significant correlation was found between all factors. These results proved that all factors were in the same structure.

\section{Discussion, Conclusion, and Recommendations}

In this study, the internal consistency coefficients of the student scale were found to be high. Cronbach's alpha for the total of the scale was calculated as $\alpha=.75$. These values indicate that the internal consistency of the scale is at 
acceptable levels. For the reliability analysis of a scale that is prepared in quantitative studies, if Cronbach's alpha value is more than .70 , then it is considered a good value (Aydin \& Aslan, 2016; Aydin \& Cinkaya, 2018; Kalayc1, 2008; Özdamar, 1999; Ulubey, Aydin, \& Toraman, 2017). For the student survey, the level at which each variable contributed to the main component by considering the principal component analysis, and the common load values of each variable's contributing level to the main component were calculated. The common load values of all items in the scale were found to be more than .50. The lowest load value was calculated as .501 in the $211^{\text {st }}$ item. The fact that the common load values were high in the study shows that item elimination was no longer necessary.

As a result of factor analysis made with principal component analysis by using Eigenvalue as 1, the conclusion was made that the scale had a five-factor structure at the first stage. These results show that the analysis should be continued on a multi-factorial structure. After this step, to examine in which factors the items were gathered, the distribution of the items to the factors was examined by varimax vertical rotation, and all items reached more than $10 \%$ difference $(<.130)$ in more than one factor. This data shows that all items in the scale have distinctive enough structure.

As a result of the research, the first factor had 4 items; the second factor had 6 items; the third factor had 3 items; the fourth factor had 3 items, and the fifth factor had 3 items. These data show us that each factor is related to the items in the scale sufficiently. The number of items in the scale that was initially 25, was reduced 19 in the final stage. The title of each factor was determined after considering the meanings of the items.

In this study, the first factor was labeled "teacher approaches," the second factor "teaching process," third factor "measurement and evaluation," the fourth factor "gains" and the fifth factor "content and teaching materials."

In this pilot scheme, the factors reached in the context of the data were related to the elements in the curriculum. Ornstein and Hunkins (2014) stated that a curriculum consists of aim, content, educational status (teaching process) and test cases. The factors reached in the study in this respect were directly related to the program elements. Items in the scale and the factors reached in the direction of these items were related to the basic principles and approach of constructivist teaching theory. The reached factors and the items they contain included points like the position of the students in the process, whether an active participation opportunity exists, teacher guidance, the appropriateness of the aims for the student level, the reality of the content for the living conditions, the level of the teacher approach, how the evaluation is made, and how much emphasis is put on cooperative learning (Andrews, 2017; Fer \& Cirık, 2007; Toraman, Aydin, \& Ulubey, 2016).

An independent group t-test was used to determine whether a difference existed between the arithmetic averages of upper (27\%) and lower (27\%) groups determined according to factor total scores. The differences were found statistically significant for all groups and were observed in favor of upper groups. These results showed that the items in the scale were sufficiently distinctive. Also, the 
correlations of all items were significant in item-total and item-remainder analyses. This indicates that all items of this scale were in the same structure.

The Pearson Product-Moment Correlation analysis found a positive correlation among all factors, and all the factors were in the same structure. These data show that the scale was compatible both on the item and factor basis and was competent to serve the intended purposes. Thus, the conclusion can be made that the scale has construct validity. The feedback obtained based on the assessments of the students who were studying at science high schools may serve an essential function in the elimination of these problems by showing the deficiencies and mistakes related to the educational issues. The hope is that this scale will lead to other research.

\section{References}

Açıkgöz, K.Ü. (2003). Aktif Öğrenme [Active Learning]. İzmir: Eğitim Dünyası Yayınları. World of Education Publications.

Aç1kgöz, K.Ü. (2009). Etkili Öğrenme ve Öğretme (8. Bask1) [Effective Learning and Teaching $\left(8^{\text {th }}\right.$ ed.) $)$. İzmir: Biliş.

Akınoğlu, O. (2004). Yapılandırmacı Öğrenme ve Coğrafya Öğretimi [Constructivist Learning and Geography Teaching]. Marmara Coğrafya Dergisi (Marmara Geography Journal), 1(10), 83-94,

Andrews, K. (2017). Culture, Curriculum, and Identity in Education. [Book Review]. Journal of Ethnic and Cultural Studies, 4(2), 99-101.

Asan, A., \& Güneş, G. (2000). Oluşturmacı Öğrenme Yaklaşımına Göre Hazırlanmış Örnek Bir Ünite Etkinliği [A Sample Unit Activity Based on Constructivist Learning Approach]. National Education Journal, 147, Ankara: MOE Publications.

Aslan, D., \& Aydin, H. (2013). Voices: Turkish students' perceptions regarding the role of supplementary courses on academic achievement. The Anthropologist, 16(3), 631643.

Aslan, D., \& Aydin, H. (2015). Evaluation of the teaching processes at science high schools based on a constructivist approach. A scale development study. Communications, $38(1 \mathrm{~A}), 472-491$.

Aslan, D., \& Aydin, H. (2016). Philosophical paradigms of constructivism: A review of literature. Usak University Journal of Educational Research, 2(2), 56-71.

Aydin, H. (2014). A comparative study between the United States and Turkey on teachers' lesson planning effort. Review of Research and Social Intervention, 46(1), 99-117.

Aydin, H., \& Aslan, D. (2016). Reliability and validity testing of a new scale for measuring attitudes toward pedagogical teacher training. Journal of Education and Learning, 5(3), 1-9.

Aydin, H., \& Cinkaya, M. (2018). Global citizenship education and diversity (GCEDS): A measure of students' attitudes related to social studies program in higher education. Journal of Multicultural Education, 12(3), 221-236. doi:10.1108/JME-05-2017-0030

Aydin, H. (2019). The effect of multiple intelligence(s) on academic success: A systematic review and meta-analysis. EURASIA Journal of Mathematics. Science and Technology Education, 15(12), 1-22. doi:10.29333/ejmste/109008.

Büyüköztürk, Ş. (2012). Veri Analizi El Kitabı .(17. Basım). Ankara: PegemA Akademi Yayınları.

Colburn, A. (2000). Constructivism: Science education's grand unifying theory. Clearing House, 74(1), 9-12. 
Dewey, J. (1939). Education and American culture. In Intelligence in the modern world, J. Ratner (ed.). New York, NY: New Library.

Driscoll, M.P. (2000). Psychology of learning for instruction. Boston, MA: Allyn \& Bacon.

Glasersfeld, E.V. (1998). Cognition, construction of knowledge, and teaching. In Constructivism in science education, M.R. Mathews (ed.), (pp. 11-30). Dordrecht: Springer.

Fer, S., \& Cırı, İ. (2007). Yapılandırmacı Öğrenme Kuramdan Uygulamaya. (Constructivist Learning: From Theory to Practice). İstanbul: Morpa.

Güneş, G ve, \& Baki, A. (2011). Dördüncü Sınıf Matematik Dersi Öğretim Programının Uygulanmasindan Yansimalar (Reflections from the Application of Fourth Grade Mathematics Course Curriculum). Hacettepe Üniversitesi Eğitim Fakültesi Dergisi, $41,192-205$.

Hall, N. \& Quinn, R. (2014). Parental Involvement at the High School Level: Parents' Perspectives. Journal of Ethnic and Cultural Studies, 1(1), 13-21.

Halpern, C. (2017). Book Review: In search of understanding: The case for constructivist classrooms. American Journal of Qualitative Research, 1(1), 32-36.

Huang, H.M., Rauch, U., \& Liaw, S.S. (2010). Investigating learners' attitudes toward virtual reality learning environments: Based on a constructivist approach. Computers \& Education, 55(3), 1171-1182.

Kalayc1, Ş. (2008). SPSS Uygulamalı Çok Değişkenli İstatistik Teknikleri. [SPSS Applied Multivariate Statistical Techniques]. Ankara: Asil.

Kaptan, F., \& Korkmaz, H. (2001). İlkögretimde Fen Bilgisi Eğitimi. Ankara: MEB. Yayincllı [Science Education in Primary Education]. Ankara: Ministry of Education. Publishing.

LaPaglia, K. (2018). Book Review: Critical pedagogy: Notes from the real world. American Journal of Qualitative Research, 2(2), 150-153.

Mahoney, M.J. (2004). What is constructivism and why is it growing? Contemporary Psychology, 49, 360-363.

Ministry of Education (MOE) (2005). İlkögretim1-5. Sinıf Programları Tanitım El Kitabı [Primary education 1-5. Grade Curricula Introductory Handbook]. Ankara: State Books.

Ornstein, A. C., \& Hunkins, F. P. (2014). Foundations, principles and theory. Thousand Oaks, CA: Sage.

Özdamar, K. (1999). Paket Programlar Ile İstatistiksel Veri Analizi [Statistical Data Analysis with Packaged Software]. Eskişehir: Kaan.

Piaget, J. (1964). Development and learning. Readings on the development of children. In Piaget Rediscovered, R.E. Ripple \& V. N. Rockcastle (eds.). Ithaca, NY: W. H. Freeman and Company Press.

Sönmez, V. (2008). Ögretim Illke ve Yöntemleri (2. Bask1) [Teaching Principles and Methods (2nd ed.)]. Ankara: An1 Publishing.

Thanasoulas, D. (2002). History of English language teaching. Retrieved from https://bit. ly/2NHLz3n.

Toraman, C., Aydin, H., \& Ulubey, O. (2016). Exploring teacher candidates' attitudes towards pedagogical teacher training based on different variables. International Education Studies, 9(9), 74-86.

Ulubey, O., Aydin, H., \& Toraman, C. (2017). Determining to which degree pedagogical teacher training serves the teaching profession: A scale development study. Transylvanian Review, 26(1), 55-74.

Vygotsky, L.S. (1997). Educational psychology. New York, NY: St. Luce Press. 
Vol. 8, No. 2 Aslan et al.: An Evaluation Constructivist Approach in High School...

Woofter, S. (2019). [Book Review]: Building equity: Policies and practices to empower all Learners. American Journal of Qualitative Research, 3(1), 136-139. https://doi. org/10.29333/ajqr/5815.

Yıldırım, A., \& Şimşek, H. (2008). Nitel Araştırma Yöntemleri (7. Baskı) [Qualitative Research Methods (7th ed.)]. Ankara: Seçkin Publishing. 


\title{
Understanding How Leadership Matters: Collective Efficacy and Student Achievement
}

\author{
By Matthew E. Haug ${ }^{*} \&$ Teresa Wasonga ${ }^{\dagger}$
}

\begin{abstract}
The purpose of this study was to examine the relationships among collective efficacy factors, as measured by the Illinois 5Essentials Survey, and college readiness scores, as reported by American College Testing (ACT), for high schools in the state of Illinois. The 5Essentials have been considered crucial to school success and therefore used to describe learning environments and as basis for decisions on school improvement. However, little research has investigated the efficacy of the 5Essentials in their impact on academic achievement. This study used Illinois 5Essentials Survey and ACT data to interrogate the value of 5Essentials. Analysis of data determined that while correlational relationships do exist among the 5Essentials (collective efficacy factors) and that some have predictive qualities for student achievement, the strengths of those relationships are, at best, weak. Outcomes of this survey provide insights that policy makers should consider when recommending the use of these factors to influence school culture and student achievement.
\end{abstract}

Keywords: collective efficacy, Illinois 5Essentials Survey, reciprocal causality, self-efficacy, student achievement, leadership

\section{Introduction}

The American public education system has long been trusted to improve the lives of individuals and to help them, among other things, rise to political, economic and social success (Bennett, 1988). While this goal has remained the same over time (Kober, 2007; Willis, 1977), the structuring of the education system has changed in response to the needs of citizenry. For example, "[i]n the 21st century, at least some postsecondary education will be necessary for economic success -even survival- in an economy where the exchange of information dominates the world of work" (ACT, 2004). High school education only is no longer good enough to attain successful quality of life. In response, government leaders have called "... for a national commitment for every American to attain at least one year of postsecondary education" (Wolniak \& Engberg, 2010). In an attempt to fulfil this commitment, the state of Illinois adopted the 5Essentials as a way to organize schools for improvement (Bryke, Sebring, Allensworth, Luppescu, \& Easton, 2010).

High school education is required to transition to college. But, high schools do not operate in a vacuum, especially when the measure of student achievement is brought to bear. Like other institutions, high schools are social organizations built upon a sense of collective efficacy, which Bandura defined as “... an organizational

*School Administrator, Central CUSD \#301, USA.

${ }^{\dagger}$ Professor, Northern Illinois University, USA. 
property and group-level attribute that represents teachers' collective beliefs about their collective power to execute a course of action that will result in a positive impact on students..." (in Evans, 2009, p. 65). When community actions result in gains for the organization, this experience feeds into future experiences and strengthens the organization as a collective. This collective is also known as organizational intentionality, whereby organizational members' work as a collective builds a sense of efficacy for the organization (Ingersoll, Sirinides, \& Dougherty, 2018; Goddard, Hoy, \& Woolfolk-Hoy, 2000). To this end, Bandura (1993) has argued that the most critical component affecting student achievement in a school is the collective efficacy, especially that of its teachers.

The perception that the collective has a positive impact on student achievement is strengthened through academic press, or "...quest for academic excellence..." (Hoy, Sweetland, \& Smith, 2002). Over time, academic press becomes a normative process with faculty believing that their efforts to bring about quality education will result in improved student performance. Ideally, this sense of reciprocal causality creates a cycle in which high levels of academic press result in high levels of student performance, which cycles back to reinforce the importance of high levels of academic press (Hoy et al., 2002). To the extent that the cycle continues, and positive impacts are observed, these cycles of success and positive impacts will influence decisions, efforts, and persistence levels among teachers and administrators (Evans, 2009). The challenge for many schools is how to identify practices for the collective that promote academic press, how to quantify these practices, how to determine the effectiveness of normative processes, and their impacts on student achievement.

Schools, especially high schools are complex public organizations that are subject to account for the use of resources and their outcomes. Because of their significant role in molding the youth of the nation, high schools continue to be targets for increased accountability and organizational effectiveness. Indeed, the No Child Left Behind Act of 2001 (NCLB) was created specifically to "...close the achievement gap with accountability, flexibility, and choice, so that no child is left behind" (NCLB, 2015). With this mandate, the federal government required that schools put in place programs that would ensure that all children, regardless of race, ethnicity, disability, socio-economic status or geographical location, would have equal opportunities for success in their school. However, complicating these efforts for school leaders are what Evans (2009) described as "social ideologies about race, class, and educational achievement...[that]...propagate the notion that white students will generally outperform African American and Hispanic students, and that wealthier students will outperform poor students on achievement and performance indicators" (p. 65). These beliefs likely influence a wide range of policies that, in turn affect schools and their communities and shape the nature of school reform efforts to meet accountability mandates. Educators as a collective function within these ideological notions. However, if educators perceive that they can execute purposeful reform plans to help all students achieve college readiness, their collective actions are likely to produce results and act as the driving force for collective efficacy in the school. 
In responding to public demands for school accountability and reforms, the state requires schools in Illinois to publish report cards which, in addition to providing student achievement data, must also "...provide feedback from, at a minimum, students in grades 6 through 12 and teachers on the instructional environment within a school..." (105 ILCS 5/2-3.153). One of the choices that schools may use to assess instructional environment is the Illinois 5Essentials Survey, which is based on 20 years of research by the University of Chicago Consortium on Chicago School Research. The survey's five components have been identified as critical to school success. They include, Effective Leaders, Collaborative Teachers, Involved Families, Supportive Environment, and Ambitious Instruction. It is assumed that the feedback given by students and teachers on each of these components provides a "...comprehensive picture of the school environment..." (UChicago Impact, 2015, par. 1-2).

Based on foundational research leading to the development of the 5Essentials, Bryk et al. (2010) conceptualized the five essentials as collective efficacy describing them as "...shared values and social cohesion of a community in responding to local problems that may arise" (p. 192). The essence being that schools are community systems made up of groups of individuals that espouse certain values and norms as a collective. In addition, they have abilities and capacities as a collective to respond to issues that arise in the process of educating students. Currently, the Illinois 5Essentials Survey is used as the appropriate tool to measure the collective efficacy of school communities in Illinois. Although this survey has been in use for a decade, there is limited research focusing on establishing its efficacy, especially in relation to appropriateness in defining the 5Esssentials as the collective efficacy factors that have positive influence on learning environment and student academic outcomes for all school in Illinois.

\section{Conceptual Framework for the Study}

Schools are systems comprised of inputs, throughputs, and outputs, and influenced by internal and external environments (Katz \& Kahn, 1978). Inputs include educators, students, budgets, and resources that come to the schools. Throughputs are the processes used to engage and educate the students, and outputs represent the learning outcomes that students achieve after experiencing the educational processes. While, inputs, throughputs, and outputs as a collective make up the internal environment of the school, the community in which the school is located constitutes the external environment. The external environment influences the school by providing resources and setting expectations for school culture and student and school outcomes. Thus, the culture and climate of a school derives from the interactions between internal and external environments. With over 20 years of research, researchers at the University of Chicago Consortium determined that the culture of a school can be defined by the levels of the practice of the five essential supports (5Essentials). Higher levels of the practice of 5Essentials “...enhance students' engagement with school and improve their 
learning outcomes" (Bryk et al., 2010, p. 46). The 5Essentials are described as follows:

Effective Leaders: The principal works with teachers to implement a clear and strategic vision for school success.

Collaborative Teachers: The staff is committed to the school, receives strong professional development, and works together to improve the school.

Involved Families: The entire school staff builds strong relationships with families and communities to support learning.

Supportive Environment: The school is safe and orderly. Teachers have high expectations for students and support students to realize their goals. Classmates also support one another.

Ambitious Instruction: Classes are academically demanding and engage students by emphasizing the application of knowledge.

(UChicago Impact, 2015, par. 1).

In their research, Bryk et al. (2010) identified Effective Leadership as the major input that drives the vision and change in the school system. Other researchers agree (Ingersoll, et al., 2018; Day \& Gurr, 2014). According to Ingersoll et al. (2018), a key element of effective instructional leadership is developing a shared vision and purpose among the faculty. For the same reason, Day and Gurr (2014) suggest that school leaders set direction with a vision focused on success and how to improve. Because leadership does not exist in a vacuum, Bryk et al. (2010) also discuss other essential supports within the school system. Accordingly, Collaborative Teachers, Supportive Environment, and Involved Families not only interact with each other, they also interact with the classroom (Ambitious Instruction) in a reciprocating relationship in response to school leadership. In other words, although Ambitious Instruction exists solely within the classroom, it is influenced indirectly by the other four essential supports. And therefore, the school system output (defined by student outcomes) is reflective of the practice of the 5Essentials (Bryk et al., 2010, p. 69) (Figure 1).

As described by Bryk et al. (2010) the composite score on the 5Essentials survey gives a sense of group-level attribute (collective efficacy) that represents the shared beliefs about the collective power to execute a course of action that will result in positive impacts on students. Bandura (1977) identifies efficacy as the perceived belief in the ability to achieve a goal in a specific situation. Bandura's (1977) model identifies four experiential sources of efficacy judgement. They include mastery experiences (performing well on a previous task, builds competence), vicarious experience (comparing competence of self to others), verbal persuasion (encouragement or discouragement by others), and emotional arousal (feelings of sensations that communicate belief in ability to achieve). The significance of these experiences is their power to influence perceptions or feelings of the ability to achieve goals which, in turn stimulates continued levels of commitment toward meeting those goals. In a school system, these experiences are likely to inspire sense of self or collective-efficacy in executing the 5Essentials. For this reason, Bryk et al. (2010) explain that collective efficacy is determined by the extent of the collective practice of 5Essentials which, in turn effect student 
achievement. In this study, the 5Essentials and efficacy factors and used synonymously.

Figure 1. Essential Supports for School Reform- 5Essentials and Student Achievement labeled in italics

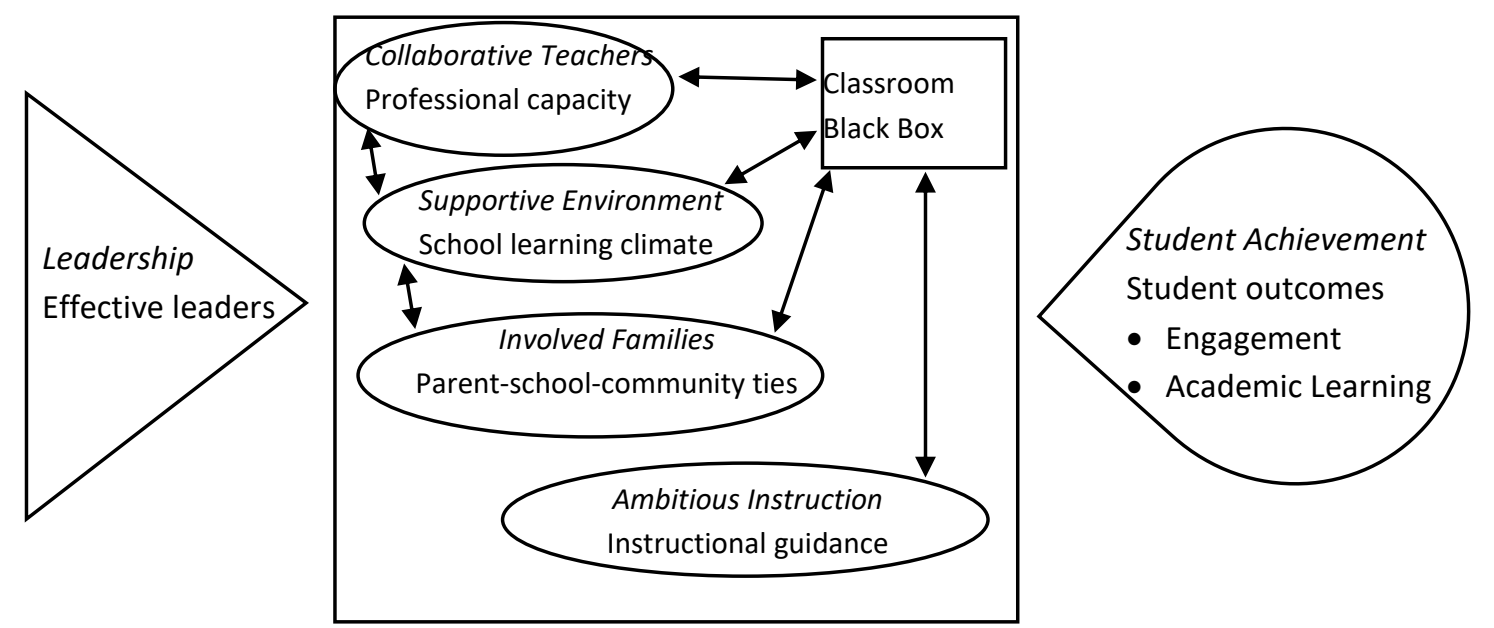

Source: Bryk et al., 2010, p. 69.

Guided by the conceptual framework above, this study examined the relationships among collective efficacy factors, as measured by the Illinois 5Essentials Survey and college readiness scores as reported by ACT for high schools in the state of Illinois. The research questions were: What are the mean scores for collective efficacy factors and high school college readiness measures; What are the relationships between high school college readiness measures and collective efficacy factors; What are the differences based on location (Chicago, suburban, rural) among college readiness measures and collective efficacy factors; and What collective efficacy factors predict college readiness?

\section{Literature Review}

The literature review focuses on research and theories that inform the concept of collective-efficacy. Such theories include social cognitive theory and selfefficacy. Collective efficacy though a new phenomenon that is still developing in the literature has promise because it is grounded in social cognitive theory and self-efficacy.

\section{Social Cognitive Theory}

Social cognitive theory posits the belief that human action and understanding is, in part, a function of observing others within a social situation and using what they have learned (through observation) to make decisions (Bandura, 2001). Social cognitive theory puts greater emphasis on the core features of human agency to “...intentionally make things happen by one's actions" (Bandura, 2001, p. 2). By 
this logic, people do not simply exist as observers of the natural world around them, instead, they use it to create and/or anticipate other experiences. Thus, through interactions with the environment, humans make decisions and gain experiences that facilitate their abilities and proclivities to make future decisions. By setting intentions, people set expectations for outcomes, establish anticipated outcomes and, using acknowledged standards, react to outcomes based upon personal and social standards (Bandura, 2001). Based upon the feedback that the individual receives and the interpretation they make from actions, one will determine capacity for success in similar future endeavors. This supports Bandura's idea of triadic reciprocal causation, in which the individual finds him or herself reflecting upon personal factors, the environment, and their behaviors to determine future decisions and the levels of efficacy towards outcomes of those decisions (Eells, 2011). Social cognitive theory thus forms the basis for selfefficacy and, by extension, collective efficacy.

\section{Self-Efficacy}

The concept of self-efficacy is defined by Hoy et al. (2002) as “...beliefs in one's capabilities to organize and execute a course of action required to produce a given attainment" (p. 78). Flowing from the umbrella of social cognitive theory and human agency, the intentional choices that a person makes to act are influenced by the belief in self to do a task. The belief in self to do the task is what distinguishes self-efficacy from concepts like self-esteem or self-worth.

According to Bandura (1977), there are four informants of efficacy. Mastery or performance accomplishments are, by far, the most powerful informants of efficacy expectations. The more success one experiences, the greater the selfefficacy expectation and the lower the negative impact that failures will have on the person. It is hereby assumed that greater mastery increases chances for persistence, and with that a person finds, through experience, that difficult situations can be overcome.

Another of Bandura's informant of efficacy expectations is vicarious experiences. Watching others engage, especially in threatening situations without adverse consequences can generate efficacy expectations of success in others. While this efficacy information is not as strong as mastery that comes through participant modeling, seeing others succeed shows that even the most anxious can eventually succeed through persistence, and seeing many others succeed is more encouraging than seeing one or none.

In addition to mastery and vicarious experiences, the third source of efficacy expectation is verbal persuasion. Verbal persuasion involves suggestions from outsiders that an individual can be successful. However, just as verbal persuasion can have significantly positive effects in building confidence, it can also have negative ramifications for the receiving individual, especially when competence expectations are raised and conditions for the person to succeed are not right. Not only will the persuader be discredited, the negative experience will further debilitate the recipient's personal efficacy and motivation to persist. 
The fourth source of efficacy expectation identified by Bandura is emotional arousal. The right amount of arousal may energize a person to action, however, higher than necessary emotional arousal generally hampers performance. People are more likely to be successful when they are not experiencing negative arousal situations. Helping people perceive the right levels of self-competence can reduce excessive arousal and can lead to action on the part of the individual if he or she is able to reduce self-doubts. "Performance successes, in turn, strengthens selfefficacy" (Bandura, 1977) and is the beginning of a positive cycle.

In studying effects of self-efficacy, Goddard, Hoy and Woolfolk-Hoy (2004) found that teachers with greater sense of self-efficacy tended to be better prepared to teach, used more innovative strategies in teaching, and tended to be more student centered. Additionally, the concepts of trust, openness, and job satisfaction were found to be related to a teacher's sense of self-efficacy and productivity (student achievement) in the classroom (Goddard et al., 2004).

\section{Collective Teacher Efficacy}

Collective efficacy is growing out of Bandura's $(1977,1993,2001)$ work and is driven by the notion of human agency -people's desire to exercise control over their lives in a variety of ways (Rotter, 1966). When groups of individuals act together to achieve common intentions based on shared beliefs, their individual agencies are extended to collective agency of the organization (Goddard et al., 2000). Goddard, et al. (2000) describe collective teacher efficacy as “...an emergent group-level attribute - the product of the interactive dynamics of the group members" (p. 5). The shared beliefs of the group members influence their capacity to make and act on decisions about desired goals. In the same notion, the collective would be associated with the levels of stress and persistence that organizations feel when targeting and planning to meet achievement outcomes. For instance, in the 15 years that the No Child Left Behind (NCLB) Act was in existence, accountability for student achievement increased and became more consequential. Because of the consequences, schools learned the goals they needed to set to raise student achievement, the policies and procedures they needed to reach these goals, and the resulting changes they needed to make after evaluation of outcomes. This organizational learning occurred as a collective effort by principals, teachers and school boards who made judgments of the faculty's abilities to make improvements in student achievement based on their context.

Like the informants of self-efficacy, organizations use mastery (performance experiences), vicarious experiences, social persuasion, and emotional arousal to strengthen or diminish the motive and capacity of its members to continue their efforts. Schools as organizations use the four experiences to develop a sense of collective efficacy as they work together towards the goals of school improvement and higher student outcomes. Bryke et al. (2010) conceptualized effective leadership, collaborative teachers, involved families, supportive environment, and ambitious instruction as collective efficacy in schools. Together, the functions of these factors reflect the collective engagement of schools' internal and external environments. 


\section{Methodology}

This was a descriptive, one-time cross-sectional study in which different groups were studied at the same time. Electronic data, based on responses from high school teachers and students that are uploaded annually by school districts in the state of Illinois and published annually online via the Illinois School Report Card, were gathered and re-organized by the researchers. Categories of reported data by each school included: county location of the school, city location of the school, percent of low-income students at the school, racial/ethnic diversity of the student population, and the percentage of students who were identified as college ready by meeting or exceeding the American College Testing (ACT) composite benchmark of 21 .

The dependent variable in the study was college readiness composite score as reported from ACT. Independent variables included percentages of students from low-income backgrounds, racial population percentages, and the 5Essentials category scores. The population $(\mathrm{N}=567)$ was public high schools in the state of Illinois whose 2015 data on, among other things, school demographics, school achievement levels, and school environment survey scores were reported by the Illinois School Report Card. The schools included in this study satisfied two criteria:

1. They posted the percentage of students meeting or exceeding a composite score of 21 on the ACT during the 2014-2015 school year, and

2. They had full reports for the Illinois 5Essentials Survey for that same period.

Of the 567 high schools reporting data to the Illinois Interactive Report Card, 379 high schools had full Illinois 5Essentials reports and college readiness reports from the ACT. These 379 schools made the sample $(n)$ for this study.

The 2015 version of the 5Essentials survey is a combination of 80 and 150 questions for student and teachers respectively, compiled into 22 measures of school climate and practices. These 22 measures are distributed among the five essentials categories namely Effective Leadership, Collaborative Teachers, Supportive Environment, Involved Families, and Ambitious Instruction. Each of these categories is rated on the degree of implementation based upon the respondents' answers as follows: Most Implementation, More Implementation, Average Implementation, Less Implementation, Least Implementation. For the purposes of this study, these ratings were assigned a numerical value ranging from 5 (Most Implementation) to 1 (Least Implementation). Reliability coefficients for each of the sub-scales based on the UChicago Consortium of Chicago School ranged from Cronbach's $\alpha=.71$ to .97 , except for one sub-scale, Ambitious Instruction which was Cronbach's $\alpha=.60$ (Klugman, Gordon, Sebring, \& Sporte, 2015). Descriptive statistics, Analysis of Variance (ANOVA), correlations, and regressions were used to analyze data. 


\section{Findings}

\section{Analysis of Mean Score Values}

Table 1 presents descriptive data on demographic variables of income and ethnicity. The results indicate that the largest concentration of schools with significant low-income students is the city of Chicago. Most high schools within Chicago had a high concentration of low-income students clustered closely around the mean (with $68 \%$ of scores falling within one standard deviation above and below the mean).

Table 1. Income and Ethnicity Mean Percentages and Standard Deviation Scores (SD)

\begin{tabular}{|l|c|c|c|c|}
\hline & $\begin{array}{c}\text { All Illinois } \\
\text { High Schools }\end{array}$ & $\begin{array}{c}\text { Chicago High } \\
\text { Schools }\end{array}$ & $\begin{array}{c}\text { Suburban High } \\
\text { Schools }\end{array}$ & $\begin{array}{c}\text { Rural High } \\
\text { Schools }\end{array}$ \\
\hline \% Low & 48.47 & 89.60 & 39.90 & 43.02 \\
Income & $(24.15)$ & $(14.04)$ & $(24.06)$ & $(16.29)$ \\
\hline \% White & 68.14 & 6.86 & 53.16 & 85.78 \\
& $(34.18)$ & $(11.45)$ & $(29.31)$ & $(18.22)$ \\
\hline \% African & 13.79 & 50.29 & 16.58 & 5.38 \\
American & $(26.25)$ & $(39.91)$ & $(26.08)$ & $(13.04)$ \\
\hline \% Hispanic & 13.20 & 38.27 & 22.20 & 5.03 \\
& $(21.00)$ & $(34.63)$ & $(19.84)$ & $(9.15)$ \\
\% Asian & 2.09 & 3.25 & 5.06 & .84 \\
\hline \% American & $(4.21)$ & $(5.42)$ & $(6.58)$ & $(1.40)$ \\
Ind. & .23 & .23 & .30 & .21 \\
\hline \% 2+ Races & $(.30)$ & $.93)$ & $(.27)$ & $(.31)$ \\
\hline \% Pacific & 2.35 & $(.99)$ & $(1.35)$ & 2.60 \\
Island. & $(2.03)$ & .12 & .08 & $(2.26)$ \\
\hline Sample Size & $(.08$ & $n=50$ & $n=84$ & $n$ \\
\hline
\end{tabular}

The largest population of schools with African American and Hispanic populations are also found in the Chicago sub-group. High schools in Chicago tended to have greater variance in African American and Hispanic populations ( $M$ $=50.29 \%, S D=39.91$ and $M=38.27 \%, S D=34.63$, respectively). High schools with large White populations were found in rural areas, representing the largest sub-group $(n=245)$.

Table 2 presents mean percentages and standard deviations for college readiness measures. Suburban high schools achieved the highest mean score values across all areas of college readiness measures. High schools in Chicago had the lowest percentage of students meeting or exceeding each of these benchmark requirements. However, observing the standard deviations for these percentages, the Chicago group of high schools had a larger spread of scores compared to suburban and rural schools. 
Table 2. College Readiness Mean Percentages and Standard Deviation Scores (SD)

\begin{tabular}{|l|c|c|c|c|}
\hline & $\begin{array}{c}\text { All Illinois } \\
\text { High Schools }\end{array}$ & $\begin{array}{c}\text { Chicago High } \\
\text { Schools }\end{array}$ & $\begin{array}{c}\text { Suburban High } \\
\text { Schools }\end{array}$ & $\begin{array}{c}\text { Rural High } \\
\text { Schools }\end{array}$ \\
\hline \% College & 39.53 & 18.94 & 47.74 & 40.91 \\
Readiness & $(18.45)$ & $(22.76)$ & $(20.67)$ & $(12.88)$ \\
\hline \% English CRB & 56.80 & 36.82 & 62.85 & 58.81 \\
& $(17.60)$ & $(23.72)$ & $(18.05)$ & $(12.56)$ \\
\hline \% Math CRB & 32.75 & 15.30 & 41.56 & 33.29 \\
& $(17.54)$ & $(20.37)$ & $(19.68)$ & $(13.12)$ \\
\hline CRB Reading & 34.34 & 15.72 & 41.01 & 35.85 \\
\% Science CRB & $(16.12)$ & $(20.14)$ & $(17.60)$ & $(11.27)$ \\
\hline \% All 4 CRB & 29.54 & 13.30 & 37.20 & 30.23 \\
& $(15.62)$ & $(18.32)$ & $(18.16)$ & $(11.13)$ \\
\hline Sample Size & 19.09 & 7.38 & 26.38 & 18.99 \\
\hline
\end{tabular}

Table 3 displays the mean values for the collective efficacy factors gathered through the Illinois 5Essentials Survey. Scores were grouped around the mid-point of the 1-5 scale, thus 3. The factor of Effective Leaders generated the lowest score, while the factor of Ambitious Instruction had the highest mean score for each subgroup. In this study, teachers and students reported great confidence in levels of instruction and presented the least confidence in the effectiveness of school leadership. The degree of standard deviation for collective efficacy factors is very small, as would be expected when observing many 5-point Likert-type scores. However, it is significant to note that the smallest variance is found among Suburban High Schools $(n=84)$ in the efficacy factor of Ambitious Instruction $(S D=.57)$.

Table 3. Collective Efficacy Mean Values and Standard Deviation Scores (SD)

\begin{tabular}{|l|c|c|c|c|}
\hline & $\begin{array}{c}\text { All Illinois } \\
\text { High Schools }\end{array}$ & $\begin{array}{c}\text { Chicago High } \\
\text { Schools }\end{array}$ & $\begin{array}{c}\text { Suburban High } \\
\text { Schools }\end{array}$ & $\begin{array}{c}\text { Rural High } \\
\text { Schools }\end{array}$ \\
\hline Effective & 2.73 & 3.02 & 2.49 & 2.75 \\
Leaders & $(.77)$ & $(.80)$ & $(.77)$ & $(.75)$ \\
\hline Collaborative & 3.05 & 3.42 & 3.20 & 2.92 \\
Teachers & $(.83)$ & $(.84)$ & $(.83)$ & $(.80)$ \\
\hline Supportive & 3.03 & 3.32 & 3.18 & 2.91 \\
Environment & $(.77)$ & $(.74)$ & $(.84)$ & $(.72)$ \\
\hline Ambitious & 3.27 & 3.66 & 3.48 & 3.12 \\
Instruction & $(.72)$ & $(.72)$ & $(.57)$ & $(.73)$ \\
\hline Involved & 3.05 & 3.36 & 3.29 & 2.91 \\
Families & $(.86)$ & $(.88)$ & $(.95)$ & $(.79)$ \\
\hline Average & 3.03 & 3.36 & 3.13 & 2.92 \\
Collective & $(.79)$ & $(.80)$ & $(.79)$ & $(.76)$ \\
Efficacy & $n=379$ & $n=50$ & $n=84$ & $n=245$ \\
\hline Sample Size & \multicolumn{3}{|}{}
\end{tabular}




\section{Differences by Location among Collective Efficacy Factors and College Readiness Measures}

To determine if there existed statistically significant differences in collective efficacy factors and college readiness measures by location, a series of one-way ANOVA tests were conducted. In each case, Post Hoc testing was done to determine where significant mean differences were. With unequal sample sizes, the Scheffe test was used.

ANOVA compared the collective efficacy factor of Effective Leadership among three groupings of high schools (Chicago, suburban, and rural). The analysis found statistically significant differences, $F(2,376)=7.98, p<.001$, but the strength of the difference, $\eta^{2}=.04$, was weak. Post Hoc testing revealed significant difference between Chicago and suburban high schools, $F(2,376)=$ $7.66, p<.01$, and between suburban and Rural high schools, $F(2,376)=3.61, p<$ .05 . ANOVA results are presented in Table 4 .

Table 4. One-Way Analysis of Variance of Effective Leadership among Chicago, Suburban and Rural High Schools

\begin{tabular}{|l|c|c|c|c|c|c|}
\hline Source & $\boldsymbol{d} \boldsymbol{f}$ & $\boldsymbol{S S}$ & $\boldsymbol{M S}$ & $\boldsymbol{F}$ & $\boldsymbol{p}$ & $\boldsymbol{\eta}^{2}$ \\
\hline Between groups & 2 & 9.18 & 4.59 & 7.98 & .00 & .04 \\
\hline Within groups & 376 & 216.28 & .58 & & & \\
\hline Total & 378 & 225.46 & & & & \\
\hline
\end{tabular}

Completing an analysis of the variance on Collaborative Teachers among Chicago, suburban and rural high schools showed a significant difference, $F(2$, $376)=9.96, p<.001$. The strength of the difference, calculated by $\eta^{2}$, was .05 (Table 5). Post Hoc testing showed statistical differences between Chicago and rural high schools, $F(2,376)=8.04, p<.01$, and between suburban and rural high schools $F(2,376)=3.87, p<.05$. The strengths of these relationships were found to be $\eta^{2}=.04$ and $\eta^{2}=.02$, with the statistical differences between Chicago and rural schools being larger.

Table 5. One-Way Analysis of Variance of Collaborative Teachers among Chicago, Suburban and Rural High Schools

\begin{tabular}{|l|c|c|c|c|c|c|}
\hline Source & $\boldsymbol{d} \boldsymbol{f}$ & $\boldsymbol{S S}$ & $\boldsymbol{M S}$ & $\boldsymbol{F}$ & $\boldsymbol{p}$ & $\boldsymbol{\eta}^{\mathbf{2}}$ \\
\hline Between groups & 2 & 13.04 & 6.52 & 9.96 & .000 & .05 \\
\hline Within groups & 376 & 246.11 & .65 & & & \\
\hline Total & 378 & 259.15 & & & & \\
\hline
\end{tabular}

Table 6 shows the results for the ANOVA for the collective efficacy factor of Supportive Environment among Chicago, suburban, and rural high schools. Analysis found a statistically significant difference among these groups, $F(2,376)$ $=8.26, p<.01$. The strength of the difference, as calculated by $\eta^{2}$, was .04 . Post Hoc testing found statistically significant differences between Chicago and rural high schools, $F(2,376)=6.11, p<.01$, and between suburban and rural high schools, $F(2,376)=3.91, p<.05$. The strengths of these differences were both weak, $\eta^{2}=.03$ and $\eta^{2}=.02$, respectively. 
Table 6. One-Way Analysis of Variance of Supportive Environment among Chicago, Suburban and Rural High Schools

\begin{tabular}{|l|c|c|c|c|c|c|}
\hline Source & $\boldsymbol{d} \boldsymbol{f}$ & $\boldsymbol{S S}$ & $\boldsymbol{M S}$ & $\boldsymbol{F}$ & $\boldsymbol{p}$ & $\boldsymbol{\eta}^{\mathbf{2}}$ \\
\hline Between groups & 2 & 9.33 & 4.67 & 8.26 & .000 & .04 \\
\hline Within groups & 376 & 212.40 & .56 & & & \\
\hline Total & 378 & 221.74 & & & & \\
\hline
\end{tabular}

Analysis of variance was conducted for Ambitious Instruction among Chicago, suburban and rural high schools (Table 7). A statistically significant difference was found, $F(2,376)=17.39, p<.01$, with the strength of the difference determined at $\eta^{2}=.08$. Post Hoc analysis indicated differences exist between Chicago and Rural high schools, $F(2,376)=12.69, p<.01, \eta^{2}=.06$, and between Suburban and Rural high schools, $F(2,376)=8.35, p<.01, \eta^{2}=.04$.

Table 7. One-Way Analysis of Variance of Ambitious Instruction among Chicago, Suburban and Rural High Schools

\begin{tabular}{|l|c|c|c|c|c|c|}
\hline Source & $\boldsymbol{d} \boldsymbol{f}$ & $\boldsymbol{S S}$ & $\boldsymbol{M S}$ & $\boldsymbol{F}$ & $\boldsymbol{p}$ & $\boldsymbol{\eta}^{\mathbf{2}}$ \\
\hline Between groups & 2 & 16.81 & 8.40 & 17.39 & .000 & .08 \\
\hline Within groups & 376 & 181.74 & .48 & & & \\
\hline Total & 378 & 198.55 & & & & \\
\hline
\end{tabular}

ANOVA was conducted on collective efficacy factor, Involved Families. Among the three groupings of Chicago, suburban and rural high schools, the analysis found statistically significant difference, $F(2,376)=10.38, p<.01, \eta^{2}=$ .05 (Table 8). In Post Hoc testing, statistical significance in group differences were found between suburban and rural high schools, $F(2,376)=6.44, p<.01, \eta^{2}=.03$, and between Chicago and rural high schools, $F(2,376)=199.89, p<.01, \eta^{2}=$ 1.00. As noted, this last test presented an effect size of 1.00.

Table 8. One-Way Analysis of Variance of Involved Families among Chicago, Suburban and Rural High Schools

\begin{tabular}{|l|c|c|c|c|c|c|}
\hline Source & $\boldsymbol{d} \boldsymbol{f}$ & $\boldsymbol{S S}$ & $\boldsymbol{M S}$ & $\boldsymbol{F}$ & $\boldsymbol{p}$ & $\boldsymbol{\eta}^{\mathbf{2}}$ \\
\hline Between groups & 2 & 14.54 & 7.27 & 10.38 & 0.00 & .05 \\
\hline Within groups & 376 & 263.50 & .70 & & & \\
\hline Total & 378 & 278.05 & & & & \\
\hline
\end{tabular}

Finally, ANOVA was conducted to analyze the differences among Chicago, suburban and rural high schools in college readiness means for percentage of students who meet the college readiness ACT benchmark of 21. Statistically significant differences (Table 9) were found among the three groups, $F(2,376)=$ 50.68, $p<.01, \eta^{2}=.21$. Post Hoc analysis showed statistically significant differences between Chicago and suburban schools, $F(2,376)=48.22, p<.01, \eta^{2}$ $=.20$; between Chicago and rural schools, $F(2,376)=37.18, p<.01, \eta^{2}=.16$; and between suburban and rural schools, $F(2,376)=5.41, p<.01, \eta^{2}=.02$. Table 10 presents results of Post Hoc analysis. 
Table 9. One-Way Analysis of Variance of College Readiness Measures among Chicago, Suburban and Rural High Schools

\begin{tabular}{|l|c|c|c|c|c|c|}
\hline Source & $\boldsymbol{d} \boldsymbol{f}$ & $\boldsymbol{S S}$ & $\boldsymbol{M S}$ & $\boldsymbol{F}$ & $\boldsymbol{p}$ & $\boldsymbol{\eta}^{\mathbf{2}}$ \\
\hline Between groups & 2 & 27323.43 & 13661.71 & 50.68 & .000 & .21 \\
\hline Within groups & 376 & 101351.08 & 269.55 & & & \\
\hline Total & 378 & 128674.51 & & & & \\
\hline
\end{tabular}

Table 10. Summary of Scheffe Post Hoc Test of College Readiness Measures among Chicago, Suburban and Rural High Schools

\begin{tabular}{|l|c|c|c|}
\hline Pair tested & $\mathbf{F}$ & $\mathbf{F}_{\text {crit }}$ & $\boldsymbol{\eta}^{\mathbf{2}}$ \\
\hline $\begin{array}{l}\text { Chicago X } \\
\text { Suburban }\end{array}$ & $48.22^{*}$ & 4.66 & .20 \\
\hline Chicago X Rural & $37.18^{*}$ & 4.66 & .16 \\
\hline Suburban X Rural & $5.41^{*}$ & 4.66 & .02 \\
\hline
\end{tabular}

$* p<.01$

\section{Correlation of College Readiness Measures and Collective Efficacy Factors}

Correlation analyses were performed on college readiness composite scores and the Illinois 5Essentials factors of Effective Leaders, Collaborative Teachers, Involved Families, Supportive Environment and Ambitious Instruction. The strongest relationship with college readiness was found between college readiness and Involved Families $(r=.49, p=.01)$, whereas the weakest relationship was found between college readiness and Effective Leaders $(r=.11, p=.05)$. This data is presented in Table 11.

Table 11. Correlations among College Readiness and Collective Efficacy Factors for Illinois High Schools $(n=379)$

\begin{tabular}{|l|c|c|c|c|c|c|}
\hline & $\begin{array}{c}\text { College } \\
\text { Readiness }\end{array}$ & $\begin{array}{c}\text { Effective } \\
\text { Leaders }\end{array}$ & $\begin{array}{c}\text { Collaborative } \\
\text { Teachers }\end{array}$ & $\begin{array}{c}\text { Supportive } \\
\text { Environment }\end{array}$ & $\begin{array}{c}\text { Ambitious } \\
\text { Instruction }\end{array}$ & $\begin{array}{c}\text { Involved } \\
\text { Families }\end{array}$ \\
\hline $\begin{array}{l}\text { Effective } \\
\text { Leaders }\end{array}$ & .11 & 1 & & & & \\
\hline $\begin{array}{l}\text { Collaborative } \\
\text { Teachers }\end{array}$ & .22 & $.68^{* *}$ & 1 & & & \\
\hline $\begin{array}{l}\text { Supportive } \\
\text { Environment }\end{array}$ & $.42^{* *}$ & $.46^{* *}$ & $.51^{* *}$ & 1 & & \\
\hline $\begin{array}{l}\text { Ambitious } \\
\text { Instruction }\end{array}$ & $.23^{* *}$ & $.29^{* *}$ & $.41^{* *}$ & $.59^{* *}$ & 1 & \\
\hline $\begin{array}{l}\text { Involved } \\
\text { Families }\end{array}$ & $.49^{* *}$ & $.50^{* *}$ & $.66^{* *}$ & $.61^{* *}$ & $.45^{* *}$ & 1 \\
\hline
\end{tabular}

Note: $* p<.05$, one-tail. $* * p<.01$, one-tail.

Looking deeper at the relationships among college readiness and demographic factors (percentage of low-income students and the percentage of ethnic minorities), the results indicate a statistically significant, strong negative correlation between the percentage of low-income students and college readiness $(r=-.82, p$ $<.01)$. Additionally, we found statistically significant correlations by percentage of the ethnic groupings and college readiness. Among the ethnic groups, the strongest relationship was a negative correlation between percentage of African 
American students and college readiness $(\mathrm{r}=-.53, \mathrm{P}<.01)$. Table 12 presents this data.

Among the regional sub-groups of Chicago, suburban, and rural schools, each group showed statistically significant moderate relationships with college readiness $(r=.31, p<.01 ; r=.64, p<.01 ; r=.26, p<.01$, respectively). The suburban schools and rural schools produced their weakest relationships among college readiness and Effective Leaders $(r=.46, p<.01$ and $r=.14, p>.05$, respectively), while the Chicago schools exhibited the weakest relationship among college readiness and Collaborative Teachers $(r=.09, p>.05)$. This was, however, closely followed by college readiness and Effective Leaders $(r=.14, p>$ $.05)$. The Pearson correlations between pairs of variables are presented in Tables 13 through 15 .

Table 12. Correlations among Percentage Low Income/ Ethnicity and College Readiness for Illinois High Schools $(\mathrm{n}=379)$

\begin{tabular}{|l|c|}
\hline & College Readiness \\
\hline \% White & $.52^{* *}$ \\
\hline \% African American & $-.53^{* *}$ \\
\hline \% Hispanic & $-.27^{* *}$ \\
\hline \% Asian & $.36^{* *}$ \\
\hline \% Low Income & $-.82^{* *}$ \\
\hline
\end{tabular}

$* p<.05$, one-tail. $* * p<.01$, one-tail.

Table 13. Correlations among College Readiness and Collective Efficacy Factors in Chicago Schools $(\mathrm{n}=50)$

\begin{tabular}{|l|c|c|c|c|c|c|}
\hline & $\begin{array}{c}\text { College } \\
\text { Readiness }\end{array}$ & $\begin{array}{c}\text { Effective } \\
\text { Leaders }\end{array}$ & $\begin{array}{c}\text { Collaborative } \\
\text { Teachers }\end{array}$ & $\begin{array}{c}\text { Supportive } \\
\text { Environment }\end{array}$ & $\begin{array}{c}\text { Ambitious } \\
\text { Instruction }\end{array}$ & $\begin{array}{c}\text { Involved } \\
\text { Families }\end{array}$ \\
\hline $\begin{array}{l}\text { Effective } \\
\text { Leaders }\end{array}$ & .14 & 1 & & & & \\
\hline $\begin{array}{l}\text { Collaborative } \\
\text { Teachers }\end{array}$ & .09 & $.82^{* *}$ & 1 & & & \\
\hline $\begin{array}{l}\text { Supportive } \\
\text { Environment }\end{array}$ & $.57^{* *}$ & $.47^{* *}$ & $.41^{* *}$ & 1 & & \\
\hline $\begin{array}{l}\text { Ambitious } \\
\text { Instruction }\end{array}$ & $.52^{* *}$ & $.41^{* *}$ & $.35^{* *}$ & $.75^{* *}$ & 1 & \\
\hline $\begin{array}{l}\text { Involved } \\
\text { Families }\end{array}$ & $.56^{* *}$ & $.61^{* *}$ & $.51^{* *}$ & $.61^{* *}$ & $.49^{* *}$ & 1 \\
\hline
\end{tabular}


Table 14. Correlations among College Readiness and Collective Efficacy Factors I

Suburban Schools $(\mathrm{n}=84)$

\begin{tabular}{|l|c|c|c|c|c|c|}
\hline & $\begin{array}{c}\text { College } \\
\text { Readiness }\end{array}$ & $\begin{array}{c}\text { Effective } \\
\text { Leaders }\end{array}$ & $\begin{array}{c}\text { Collaborative } \\
\text { Teachers }\end{array}$ & $\begin{array}{c}\text { Supportive } \\
\text { Environment }\end{array}$ & $\begin{array}{c}\text { Ambitious } \\
\text { Instruction }\end{array}$ & $\begin{array}{c}\text { Involved } \\
\text { Families }\end{array}$ \\
\hline $\begin{array}{l}\text { Effective } \\
\text { Leaders }\end{array}$ & $.46^{* *}$ & 1 & & & & \\
\hline $\begin{array}{l}\text { Collaborative } \\
\text { Teachers }\end{array}$ & $.62 * *$ & $.73^{* *}$ & 1 & & & \\
\hline $\begin{array}{l}\text { Supportive } \\
\text { Environment }\end{array}$ & $.81^{* *}$ & $.57^{* *}$ & $.74 * *$ & 1 & & \\
\hline $\begin{array}{l}\text { Ambitious } \\
\text { Instruction }\end{array}$ & $.48^{* *}$ & $.48^{* *}$ & $.53^{* *}$ & $.55^{* *}$ & 1 & \\
\hline $\begin{array}{l}\text { Involved } \\
\text { Families }\end{array}$ & $.80^{* *}$ & $.58^{* *}$ & $.72^{* *}$ & $.72^{* *}$ & $.55^{* *}$ & 1 \\
\hline
\end{tabular}

$* p<.05$, one-tail. $* * p<.01$, one-tail.

Table 15. Correlations among College Readiness and Collective Efficacy Factors in Rural Schools (245)

\begin{tabular}{|l|c|c|c|c|c|c|}
\hline & $\begin{array}{c}\text { College } \\
\text { Readiness }\end{array}$ & $\begin{array}{c}\text { Effective } \\
\text { Leaders }\end{array}$ & $\begin{array}{c}\text { Collaborative } \\
\text { Teachers }\end{array}$ & $\begin{array}{c}\text { Supportive } \\
\text { Environment }\end{array}$ & $\begin{array}{c}\text { Ambitious } \\
\text { Instruction }\end{array}$ & $\begin{array}{c}\text { Involved } \\
\text { Families }\end{array}$ \\
\hline $\begin{array}{l}\text { Effective } \\
\text { Leaders }\end{array}$ & .14 & 1 & & & & \\
\hline $\begin{array}{l}\text { Collaborative } \\
\text { Teachers }\end{array}$ & $.26^{* *}$ & $.67^{* *}$ & 1 & & & \\
\hline $\begin{array}{l}\text { Supportive } \\
\text { Environment }\end{array}$ & $.37^{* *}$ & $.43^{* *}$ & $.40^{* *}$ & 1 & & \\
\hline $\begin{array}{l}\text { Ambitious } \\
\text { Instruction }\end{array}$ & $.26^{* *}$ & $.24 * *$ & $.33^{* *}$ & $.54 * *$ & 1 & \\
\hline $\begin{array}{l}\text { Involved } \\
\text { Families }\end{array}$ & $.51^{* *}$ & $.49^{* *}$ & $.64 * *$ & $.52^{*}$ & $.36^{*}$ & 1 \\
\hline
\end{tabular}

${ }^{*} p<.05$, one-tail. $* * p<.01$, one-tail.

\section{Predicting College Readiness Using Collective Efficacy Factors}

Multiple linear regression was conducted on the full sample to predict college readiness scores based on the collective efficacy factors of Effective Leaders, Collaborative Teachers, Supportive Environment, Ambitious Instruction and Involved Families. A significant regression equation was found $[F(5,373)=33.41$, $p<.05$ ], with an Adjusted $\mathrm{R}^{2}$ of .30 . Table 16 provides a full summary output of this regression.

Only three of the five collective efficacy factors (Effective Leaders, Supportive Environment, and Involved Families) were found to meet a minimum significance level $(p<.05)$ acceptable to this study. Another regression was run with the remaining significant variables and Step 2 shows these results. A final regression was run with the two variables (Supportive Environment and Involved Families) with beta values demonstrating positive impact on the relationship with the constant (college readiness scores). Step 3 of Table 16 displays the results of this regression. In this instance, and with the removal of Effective Leaders as an influencing variable, Supportive Environment and Involved Families produced a 
statistically significant regression equation $[F(1,375)=19.93, p<.001]$, with an Adjusted $\mathrm{R}^{2}$ of .26 .

Similar regression analysis was conducted to examine the predictive qualities of collective efficacy on college readiness based upon location. Tables 17, 18 and 19 display the data output from these regressions for collective efficacy factors meeting a minimum level of significance of $p<.05$.

Table 16. Summary of Regression Analysis of Collective Efficacy Factors Predicting College Readiness for Illinois High Schools $(\mathrm{n}=379)$

\begin{tabular}{|l|c|c|c|}
\hline Variable & $\boldsymbol{B}$ & $\boldsymbol{S E} \boldsymbol{B}$ & B \\
\hline Step 1 & & & \\
\hline Constant & 9.89 & 4.18 & \\
\hline Effective Leaders & -4.33 & 1.42 & $-.18^{*}$ \\
\hline Collaborative Teachers & -2.36 & 1.53 & -.11 \\
\hline Supportive Environment & 7.11 & 1.49 & $.30^{* *}$ \\
\hline Ambitious Instruction & -1.78 & 1.38 & -.07 \\
\hline Involved Families & 10.80 & 1.36 & $.50^{* *}$ \\
\hline Step 2 & & & \\
\hline Constant & 6.45 & 3.67 & \\
\hline Effective Leaders & -5.45 & 1.22 & $-.23^{* *}$ \\
\hline Supportive Environment & 6.09 & 1.34 & $.25^{* *}$ \\
\hline Involved Families & 9.67 & 1.23 & $.45^{* *}$ \\
\hline Step 3 & & & \\
\hline Constant & .894 & 3.54 & \\
\hline Supportive Environment & 4.77 & 1.34 & $.20^{* *}$ \\
\hline Involved Families & 7.93 & 1.20 & $.37^{* *}$ \\
\hline
\end{tabular}

Note: $R^{2}=.31$ for Step $1, \Delta R^{2}=-.01$ for Step $2(p=.10), \Delta R^{2}=-.04$ for Step $3(p<.001)$. $* p<.05 . * * p<.001$.

Table 17 shows the results of a regression analysis conducted to predict the influence of collective efficacy factors on college readiness scores at Chicago high schools. In the first step, a statistically significant regression line equation was found $[F(5,44)=9.48, p<.001]$ with an Adjusted $\mathrm{R}^{2}$ of .46 . Finding only one collective efficacy factor (Involved Families) to be statistically significant within this sub-group, a second regression was conducted with a statistically significant equation line $[F(1,48)=22.49, p<.001]$ and an Adjusted $\mathrm{R}^{2}$ value of .31 , indicating that this factor alone accounts for $31 \%$ of the variance in college readiness scores in Chicago high schools

Table 18 presents a summary of regression analysis data for significant collective efficacy factors predicting college readiness in suburban high schools. The analysis found a statistically significant regression equation line $[F(5,78)=$ 52.91, $p<.001]$ and an Adjusted $\mathrm{R}^{2}$ of .76. The two factors, Supportive Environment and Involved Families, were found to be statistically significant and a second regression analysis was conducted which removed the influence of Effective Leaders, Collaborative Teachers and Ambitious Instruction from the model. Step 2 of Table 20 shows the results of this analysis that resulted in a 
statistically significant regression line $[F(2,81)=126.54, p<.001]$ and an Adjusted $\mathrm{R}^{2}$ of .75 .

Table 17. Summary of Regression Analysis of Collective Efficacy Factors Predicting College Readiness in Chicago High Schools $(\mathrm{n}=50)$

\begin{tabular}{|l|c|c|c|}
\hline Variable & $\boldsymbol{B}$ & $\boldsymbol{S E} \boldsymbol{B}$ & $\boldsymbol{\beta}$ \\
\hline Step 1 & & & \\
\hline Constant & -43.08 & 13.81 & \\
\hline Effective Leaders & -7.83 & 5.63 & -.27 \\
\hline Collaborative Teachers & -4.15 & 4.95 & -.15 \\
\hline Supportive Environment & 8.46 & 5.33 & .28 \\
\hline Ambitious Instruction & 9.79 & 5.01 & .21 \\
\hline Involved Families & 13.96 & 3.84 & $.54^{* *}$ \\
\hline Step 2 & & & \\
\hline Constant & -30.41 & 10.75 & \\
\hline Involved Families & 14.69 & 3.10 & $.57^{* *}$ \\
\hline
\end{tabular}

Note: $R^{2}=.52$ for Step $1, \Delta R^{2}=-.20$ for Step $2(p<.05) . * * p<.001$.

Table 18. Summary of Regression Analysis of Collective Efficacy Factors Predicting College Readiness in Suburban High Schools $(\mathrm{n}=84)$

\begin{tabular}{|l|c|c|c|}
\hline Variable & $\boldsymbol{B}$ & $\boldsymbol{S E} \boldsymbol{B}$ & $\boldsymbol{\beta}$ \\
\hline Step 1 & & & \\
\hline Constant & -17.40 & 6.97 & -.08 \\
\hline Effective Leaders & -2.08 & 2.16 & -.12 \\
\hline Collaborative Teachers & -2.95 & 2.51 & $.57^{* *}$ \\
\hline $\begin{array}{l}\text { Supportive } \\
\text { Environment }\end{array}$ & 14.129 & 2.21 & -.03 \\
\hline Ambitious Instruction & -.96 & 2.47 & $.54^{* *}$ \\
\hline Involved Families & 11.62 & 1.88 & \\
\hline Step 2 & & & $.48^{* *}$ \\
\hline Constant & -22.63 & 4.59 & $.46^{* *}$ \\
\hline $\begin{array}{l}\text { Supportive } \\
\text { Environment }\end{array}$ & 11.93 & 1.95 & \\
\hline Involved Families & 9.88 & 1.72 & \\
\hline
\end{tabular}

Note: $R^{2}=.76$ for Step $1, \Delta R^{2}=-.02$ for Step $2(p=.18) . * * p<.001$.

Table 19 provides a summary of results for a regression analysis of statistically significant collective efficacy factors in rural high schools. Again, multiple steps were taken in this analysis to attempt to determine the collective efficacy factors with the greatest predictive influence on college readiness scores for rural high schools. In the initial regression, all five collective efficacy factors accounted for $31 \%$ of the variance in the test $\left[R^{2}=.31, F(5,239)=21.14\right]$, with an Adjusted $\mathrm{R}^{2}$ value of .29. Three collective efficacy factors (Effective Leaders, Supportive Environment and Involved Families) were found to meet a minimum significance threshold of $p<.05$. These three factors accounted for $31 \%$ of the variance in the test $\left[R^{2}=.31, F(3,241)=35.33, p<.001\right]$, with an Adjusted $\mathrm{R}^{2}$ value of .30 . As with the regression analysis of the full sample of Illinois high schools, a third regression was run for the two variables (Supportive Environment and Involved 
Families) with beta values demonstrating positive impact on the relationship with the constant (college readiness scores). In this step of the model, the two factors accounted for $28 \%$ of the variance in the test $\left[R^{2}=.28, F(2,242)=46.67, p<\right.$ .001 ], with an Adjusted $\mathrm{R}^{2}$ value of .27 . The summary of regression statistics is presented in Table 19.

Table 19. Summary of Regression Analysis of All Collective Efficacy Factors Predicting College Readiness in Rural High Schools $(\mathrm{n}=245)$

\begin{tabular}{|l|c|c|c|}
\hline Variable & $\boldsymbol{B}$ & $\boldsymbol{S E} \boldsymbol{B}$ & $\boldsymbol{\beta}$ \\
\hline Step 1 & & & \\
\hline Constant & 15.23 & 3.73 & $-.18^{*}$ \\
\hline Effective Leaders & -3.03 & 1.29 & -.04 \\
\hline Collaborative Teachers & -.62 & 1.36 & $.18^{*}$ \\
\hline $\begin{array}{l}\text { Supportive } \\
\text { Environment }\end{array}$ & 3.17 & 1.29 & .04 \\
\hline Ambitious Instruction & .61 & 1.15 & $.52^{* *}$ \\
\hline Involved Families & 8.48 & 1.24 & \\
\hline Step 2 & & & $.20^{*}$ \\
\hline Constant & 15.88 & 3.34 & $.51^{* *}$ \\
\hline Effective Leaders & -3.35 & 1.09 & \\
\hline $\begin{array}{l}\text { Supportive } \\
\text { Environment }\end{array}$ & 3.48 & 1.15 & $.15^{*}$ \\
\hline Involved Families & 8.29 & 1.10 & $.44^{* *}$ \\
\hline Step 3 & & & 3.21 \\
\hline Constant & 12.48 & 1014 & \\
\hline $\begin{array}{l}\text { Supportive } \\
\text { Environment }\end{array}$ & 2.65 & 1.05 & $.05)$ \\
\hline Involved Families & 7.13 & & \\
\hline
\end{tabular}

Note: $R^{2}=.31$ for Step $1, \Delta R^{2}=-.00$ for Step $2(p=.81), \Delta R^{2}=-.03$ for Step $3(p<.05)$.

$* p<.05$. ** $p<.001$.

As a final examination of the data, regression analysis was performed to determine if the percentage of low-income students in school, or the percentage of a specific ethnic group, could predict college readiness. A statistically significant regression equation was found $[F(8,370)=125.47, p<.001]$, with an Adjusted $\mathrm{R}^{2}$ of .73. Two variables were found to meet the required level of significance for this study ( $p<.05)$ : \% Low Income and \% Asian. A second regression was conducted and a statistically significant regression equation was constructed $[F(2,376)=$ 489.76, $p<.001$ ], with an Adjusted $\mathrm{R}^{2}$ of .72. Table 20 displays these results. 
Table 20. Summary of Regression Analysis of Demographic Data Predicting College Readiness for Illinois High Schools $(\mathrm{n}=379)$

\begin{tabular}{|c|c|c|c|}
\hline Variable & $\boldsymbol{B}$ & $S E B$ & $\boldsymbol{\beta}$ \\
\hline \multicolumn{4}{|l|}{ Step 1} \\
\hline Constant & 31.80 & 46.76 & \\
\hline$\%$ Low Income & -.60 & .04 & $-.79 * * *$ \\
\hline$\%$ White & .33 & .47 & .61 \\
\hline$\%$ African American & .32 & .47 & .45 \\
\hline \% Hispanic & .38 & .47 & .43 \\
\hline$\%$ Asian & 1.28 & .49 & $.29 * *$ \\
\hline \% American Indian & 2.54 & 1.82 & .04 \\
\hline$\% 2+$ Races & .87 & .54 & .10 \\
\hline$\%$ Pacific Islander & .42 & 2.92 & .00 \\
\hline \multicolumn{4}{|l|}{ Step 2} \\
\hline Constant & 66.24 & 1.20 & \\
\hline \% Low Income & -.60 & .02 & $-.78 * * *$ \\
\hline$\%$ Asian & 1.04 & .12 & $.24 * * *$ \\
\hline
\end{tabular}

Note: $R^{2}=.73$ for Step $1, \Delta R^{2}=-.008$ for Step $2(p<.001) .{ }^{*} p<.05 .{ }^{* *} p<.01 . * * * p<.001$.

\section{Discussion}

At the beginning of this study, the suggested framework (systems theory) was used to hypothesize the relationships among collective efficacy factors and student achievement. In this framework, Effective Leaders, or leadership, was viewed as the driving force for organizational change and reform in schools (Bryk et al., 2010). Indeed, research has reported the importance of strong leadership to school improvement. For example, Calik, Sezgin, Kavgaci and Kilinc (2012) found there to be a significant relationship between effective instructional leadership (as perceived by teachers) and collective efficacy of teachers. Ingersoll et al. (2018) claimed that good school leadership is tied to higher student achievement. Leithwood and Jantzi (1999) found that principals impact student engagement. However, data in this study shows minimal positive and sometimes negative correlations between leadership and student achievement, especially in comparison to other efficacy factors. Effective Leaders consistently demonstrated lower correlations with student achievement even though it had the highest correlations with Collaborative Teachers. Despite this finding, Collaborative Teachers also consistently demonstrated lower correlations with student achievement compared to Supportive Environment and Involved Families.

Studies indicate that leaders provide vision and direction for their organization to operate, ensure effective and efficient use of resources, and produce needed outcomes (Ingersoll et al., 2018; Day \& Gurr, 2014; Leithwood \& Jantzi, 1999). Ross and Gray (2006) found that transformational leadership has positive impact on teacher collective efficacy and, as a result on increasing the perceived capacity of teachers to improve student achievement. These findings suggest an indirect effect of leaders on student achievement gains. Indirect effects may explain the minimal and weak correlation results found between Effective Leaders and student 
achievement. The study found some negative impacts when leadership was used as a predictor of student achievement, specifically among students in the city of Chicago. These findings raise questions, not only about our understandings of direct and indirect roles that school leaders play in the development of collective efficacy levels and student achievement, but also the efficacy of the instrument itself (5Essentials Survey) and the use of the five essentials as factors critical to learning environment.

The study found moderate to high correlations between school leadership and the other efficacy factors with the least correlation found between Effective Leaders and Ambitious Instruction and the highest between Effective Leaders and Collaborative Teachers. In terms of student achievement, the highest correlations with efficacy factors were found between College Readiness and Involved Families followed by Supportive Environment. It seems, from this study that while school leadership has higher effects on teacher collaboration; teacher collaboration has the least effects on College Readiness/student achievement. On the other hand, collective efficacy factors of Involved Families and Supportive Environment predicted academic achievement (College Readiness), thus having the higher effects. In other words, a supportive environment in school and involved families seem to have greater impact on high school success compared to effective leader and teachers.

While these findings may point to the need for school leaders and their communities to focus on factors related to involving families and creating supportive environments (Calik et al., 2012); they also create the need to re-think the roles of school leaders and teachers in relation to high school student achievement. The questions that this study raises are: why did ambitious instruction not predict academic outcomes and why was ambitious instruction rated so highly by teachers and students? Donohoo, Hattie and Eells (2018) suggest that the role of the school leader is to "...help educators make the link between their collective actions and student outcomes" (p. 42). This research shows a gap between teacher actions and student achievement and suggests that teacher collective actions should focus on improving involvement of families and creating supportive environments in high schools. These may be done through identification and engagement with Bandura's efficacy informants that include mastery of performance accomplishments, vicarious experiences, verbal persuasions, and emotional arousals. As suggested by Bandura (1993), the practice of efficacy informants in the spirit of reciprocity can strengthen the relevant collective efficacy factors and their impacts on students' academic outcomes.

\section{Conclusions and Implications}

This study found that student achievement, as measured by college readiness, is most impacted by the involvement of families, followed by the supportive learning environments as perceived by teachers and students in response to the 5Essentials survey. This finding is supported by other research. For example, the development of peer and family networks, such as those discussed by Wolniak and 
Engberg (2009), Young, Johnson, Hawthorne and Pugh (2011), and Nelson and DeBacker (2008), show that positive experiences in high schools lead to secondary and post-secondary school success. Positive experiences, both personal and vicarious are the sources of positive connections to school and the development of a school-going culture, as described by Conley (2008). It is therefore, incumbent upon high schools to create greater opportunities for families to become engaged in the communal life of their high school. Specifically, school leaders should enable community involvement in the development and evaluation of school curricula, understanding of the school improvement planning process and knowledge of resources that can positively impact student academics, and exposure to educational experiences in which students and their families gain firsthand understanding and knowledge of the educational environment and how to navigate it. Just as Conley (2008) affirmed, the development of college knowledge leads to success in post-secondary schools and therefore, families should develop a deeper understanding of the high school system and build a sense of connectedness with opportunities for vicarious experiences, verbal persuasion, and emotional arousal for greater levels of collective efficacy and student achievement.

It is of the essence that schools take steps to create supportive environments that enable children to experience mastery in addition to the above-mentioned efficacy factors, specifically students that are in schools that serve large numbers of families of low-income. From the data presented in this study, along with research by Evans (2009) and Gordon, Klugman, Sebring and Sporte (2016), a strong relationship exists between low income status and low achievement scores. For this reason, ensuring that students see the learning environment as safe and welcoming is a critical first step to support learning. Making sure that interventions that relate to efficacy factors are in place so that when students experience academic and/or social challenges, actions that help them achieve some level of success and signals that perseverance is important, can be taken immediately.

It is essential that a clear, consistent message that defines rigorous instruction as it relates to student outcomes is provided for students and teachers in schools. In this study, even though Chicago high schools posted the lowest percentage of students meeting college readiness benchmarks, they reported the highest incidence of perceived levels of Ambitious Instruction. The perceived levels of ambitious instruction did not yield expected or predict academic outcomes. Considering that research that is the foundation for the 5Essentials Survey was done in Chicago schools (Gordon et al., 2016; Bryk et al., 2010), the hypothesis that the presence or practice of 5Essentials should have positive impacts on academic outcomes should have been especially true in Chicago schools. However, schools in Chicago reported high scores in collective efficacy factors, specifically Ambitious Instruction, but this did not correlate positively with or predict College Readiness as would be expected. Involved Families was the common predictor of student achievement in all groups with Supportive Environment being a predictor among rural and suburban high schools. This finding points to the unique challenges present in urban and low-income environments including extreme poverty, lowered expectations, lack of resources 
to create supportive environments for students, and perpetual lower academic achievement (Gehrke, 2005). The grip of these challenges seems too strong that even high levels of Ambitious Instruction cannot mitigate their effects. These challenges likely distort conceptualization of academic rigor to the extent that what students perceive as rigor does not yield high academic outcomes. Chicago schools had the lowest percentage of students that are college ready and the largest standard deviation, indicating the existence of extremes (absolute poverty and wealth) and the intensity of impacts. We recommend further investigation into the mismatch between student perceptions of academic rigor and academic achievement and to contextualize the usefulness of the 5Essentials in advancing learning in high schools and the use of the 5Essential Survey to determine school needs or school culture.

Based on the conceptual framework used in this study and our findings, we suggest a revised conception of the functions of the 5Essentials. First, we see Effective Leaders not just as inputs, but as major and active part of all aspects of throughput in the organization. The leaders serve as guides creating the parameters within which Collaborative Teachers interact and deliver Ambitious Instruction. Secondly, around the leader, teachers, and students is a Supportive Environment that cultivates safety, high expectations, and care for one another within the school. And thirdly, the supportive environment is enriched by strong relations with families and communities (Involved Families) who regularly access the school to support the school and the students.

\section{References}

ACT. (2004). On course for success: A close look at selected high school courses that prepare all students for college and work. Retrieved July 5, 2012, from https://bit. ly/37xzvcG.

Bandura, A. (1977). Self-efficacy: Toward a unifying theory of behavioral change. Psychological Review, 84(2), 191-215. Retrieved December 30, 2015, from https://bit.ly/30WinLm.

Bandura, A. (1993). Perceived self-efficacy in cognitive development and function. Educational Psychologist, 28(2), 117-148. Retrieved December 30, 2015, from https://bit.ly/2Gvnb0E.

Bandura, A. (2001). Social cognitive theory: An agentic perspective. Annual Review of Psychology, 52, 1-26. Retrieved on October 10, 2014 from https://bit.ly/2tTQCqK

Bennett, W.J. (1988). American education: making it work. A report to the president and the American people. (DOE Publication No. ED 289 959). Washington, D.C.: U.S. Government Printing Office. Retrieved January 25, 2016, from https://bit.ly/2R TKV48.

Bryk, A.S., Sebring, P.B., Allensworth, E., Luppescu, S. \& Easton, J.Q. (2010). Organizing schools for improvement: lessons from Chicago. Chicago, IL: The University of Chicago Press.

Calik, T., Sezgin, F., Kavgaci, H., \& Kilinc, A.C. (2012). Examination of relationships between instructional leadership of school principals and self-efficacy of teachers and collective teacher efficacy. Educational Sciences: Theory \& Practice, 12(4), 24982504. Retrieved January 1, 2016, from https://bit.ly/2OiipZ5. 
Conley, D.T. (2008). Rethinking college readiness. New Directions for Higher Education, 144, 3-13.

Day, C., \& Gurr, D. (2014). Leading schools successfully. In Leading Schools Successfully: Stories from the Field, C. Day \& D. Gurr (eds), (pp.1-6). New York: Routledge.

Donohoo, J., Eells, R.J., \& Hattie, J. (2018). The power of collective efficacy. Educational Leadership, 75(6), 41-44.

Eells, R.J. (2011). Meta-Analysis of the relationship between collective teacher efficacy and student achievement. Dissertations. Paper 133. Retrieved December 30, 2015 from https://bit.ly/38HlnOh.

Engberg, M.E., \& Wolniak, G.C. (2009). Examining the effects of high school contexts on postsecondary enrollment. Research in Higher Education, 51, 132-153. Retrieved November 13, 2016, from https://bit.ly/3184euR.

Evans, A. (2009). No Child Left Behind and the quest for educational equity: The role of teachers' collective sense of efficacy. Leadership and Policy in Schools, 8, 64-91.

Gehrke, R.S. (2005). Poor schools, poor students, successful teachers. Kappa Delta Pi Record, 42(1), 14-17. Retrieved November 11, 2016, from https://bit.ly/2tTnGz5.

Goddard, R.D., Hoy, W.K., \& Woolfolk-Hoy, A. (2000). Collective teacher efficacy: Its meaning, measure and impact on student achievement. American Educational Research Journal, 37(2), 479-508.

Goddard, R.D., Hoy, W.K., \& Woolfolk-Hoy, A. (2004). Collective efficacy beliefs: theoretical developments, empirical evidence, and future directions. Educational Researcher, 33(3), 3-13. Retrieved December 30, 2015 from https://bit.ly/2TZGTtG

Gordon, M., Klugman, J., Sebring, P.B., \& Sporte, S. (2016). Expanding the 5Es from Chicago to Illinois: How the 5E's relationship to student outcomes varies by content. Society for Research on Educational Effectiveness. Spring Conference Abstract template retrieved on November 01, 2016 from https://bit.ly/37yRiAu.

Hoy, W.K., Sweetland, S.R., \& Smith, P.A. (2002). Toward an organizational model of achievement in high schools: The significance of collective efficacy. Educational Administration Quarterly, 38(1), 77-93. Retrieved November 21, 2015, from https://bit.ly/2vlp5yG.

ILCS. $\S \S 105-5 / 10-17$ a (n.d.) Retrieved December 28, 2015 from https://bit.ly/36v5XLK.

Ingersoll, R. M., Sirinides, P., \& Dougherty, P. (2018). Leadership matters: Teachers' roles in school decision making and school performance. American Educator, 42(1), 13-18.

Katz, D. \& Kahn, R.L. (1978). The social psychology of organizations, 2 ed. New York: John Wiley \& Sons.

Klugman, J., Gordon, M.F., Sebring, P.B. \& Sporte, S.E. (2015). A first look at the 5Essentials in Illinois schools. Chicago, IL: UChicago, Consortium on Chicago School Research. Retrieved January 30, 2017 from https://bit.ly/36tFyxT.

Kober, N. (2007). Why we still need public schools: Public education for the common good. Washington, D.C.: Center on Education Policy. Retrieved on March 29, 2016 from https://bit.ly/2RwSZsr.

Leithwood, K., \& Jantzi, D. (1999). The relative effects of principal and teacher sources of leadership on student engagement with school. Education Administration Quarterly, 35(5), 679-706.

Nelson, R.M., \& DeBacker, T. K. (2008). Achievement motivation in adolescents: The role of peer climate and best friends. The Journal of Experimental Education, 76(2), 170-189. Retrieved June 10, 2012, from https://bit.ly/2uCpRqU.

No Child Left Behind Act of 2001, 20 U.S.C. $\$ 6319$ (NCLB) (2015). Retrieved February 6, 2016, from https://bit.ly/2RzGcWh. 
Ross, J.A. \& Gray, P. (2006). School leadership and student achievement: The mediating effects of teacher beliefs. Canadian Journal of Education, 29(3), 798-822. Retrieved on December 30, 2015 from https://bit.ly/2tZPNg7.

Rotter, J.B. (1966). Generalized expectancies for internal versus external control of reinforcement. Psychological Monographs: General and Applied, 80(1), Whole No. 609). Retrieved August 23, 2015, from https://bit.ly/2O2T9FK

UChicago Impact. (2015). Illinois 5Essentials FAQs. Retrieved December 28, 2015 from https://bit.ly/2vuv8Bh.

Willis, P. (1977). Learning to labor: How working class kids get working class jobs. New York: Columbia University Press.

Wolniak, G.C., \& Engberg, M.E. (2010). Academic achievement in the first year of college: Evidence of the pervasive effects of the high school context. Research in Higher Education, 51, 451-467. Retrieved on June 10, 2012, from_https://bit.ly/ 2Rx7pZB

Young, A., Johnson, G., Hawthorne, M., \& Pugh, J. (2011). Cultural predictors of academic motivation and achievement: A self-deterministic approach. College Student Journal, 45(1), 151-163. Retrieved on June 10, 2012, from_https://bit.ly/2O $7 \mathrm{~d} 2 \mathrm{vv}$. 